GA-A15673

UC-77

\title{
THE EFFECTS OF SURFACE CONDITION ON THE CORROSION OF CANDIDATE STRUCTURAL MATERIALS IN A SIMULATED HTGR-GT ENVIRONMENT
}

\author{
by \\ L. D. THOMPSON \\ MASTER
}

\begin{abstract}
Prepared under
Contract DE-AT03-76ET35300

for the San Francisco Operations Office

Department of Energy
\end{abstract}

DATE PUBLISHED: FEBRUARY 1980

\section{GENERAL ATOMIC COMPANY}




\section{DISCLAIMER}

This report was prepared as an account of work sponsored by an agency of the United States Government. Neither the United States Government nor any agency Thereof, nor any of their employees, makes any warranty, express or implied, or assumes any legal liability or responsibility for the accuracy, completeness, or usefulness of any information, apparatus, product, or process disclosed, or represents that its use would not infringe privately owned rights. Reference herein to any specific commercial product, process, or service by trade name, trademark, manufacturer, or otherwise does not necessarily constitute or imply its endorsement, recommendation, or favoring by the United States Government or any agency thereof. The views and opinions of authors expressed herein do not necessarily state or reflect those of the United States Government or any agency thereof. 


\section{DISCLAIMER}

Portions of this document may be illegible in electronic image products. Images are produced from the best available original document. 


\section{NOTICE}

This report was prepared as an account of work sponsored by an agency of the United States Government. Neither the United States nor any agency thereof, nor any of their employees, makes any warranty, expressed or implied, or assumes any legal liability or responsibility for any third party's use or the results of such use of any information, apparatus, product or process disclosed in this report, or represents that its use by such third party would not infringe privately owned rights.

Printed in the United States of America

Available from

National Technical Information Service

U.S. Department of Commerce 5285 Port Royal Road

Snrinofiald Virrinin गつ1 
GA-A15673

UC-77

\title{
THE EFFECTS OF SURFACE CONDITION ON THE CORROSION OF CANDIDATE STRUCTURAL MATERIALS IN A SIMULATED HTGR-GT ENVIRONMENT
}

\author{
by \\ L. D. THOMPSON
}

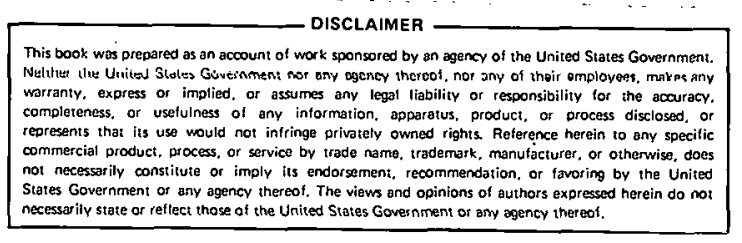

Prepared under

Contract DE-AT03-76ET35300

for the San Francisco Operations Office

Department of Energy

\author{
GENERAL ATOMIC PROJECT 6400 \\ DATE PUBLISHED: FEBRUARY 1980
}

\section{GENERAL ATOMIC COMPANY}


THIS PAGE

\section{WAS INTENTIONALLY LEFT BLANK}


ABSTRACT

A simulated high-temperature gas-cooled reactor (HTGR) helium environment has been used to study the effects of surface finish conditions on the subsequent elevated-temperature corrosion behavior of key candidate structural materials. The envirunment contained helium with $500 \mu \mathrm{atm}$

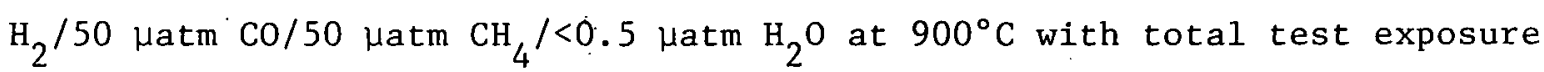
durations of 3000 hours. Specimens with lapped, grit-blasted, pickled, and preoxidized surface conditions were studied. Materials tested included two cast superalloys, IN 100 and IN 713LC; one centrifugally cast hightemperature alloy, $\mathrm{HK} 40$; one oxide-dispersion-strengthened alloy, Inconel MA 754; and three wrought high-temperature alloys, Hastelloy Alloy X, Inconel Alloy 617, and Alloy $800 \mathrm{H}$.

This environment is known to be oxidizing, as well as carburizing, with the nature and the degree of attack being dependent upon alloy chemistry. The most serious corrosion mechanism is carburization resulting in the enhanced precipitation of metal carbides both intergranularly and intragranularly. Variations in corrosion behavior were noted with the different surface finishes. Huwever, the prednminant observation was that preoxidation treatments at $900^{\circ} \mathrm{C}$ in air were effective in controlling the carburization of the two wrought alloys, Hastelloy $X$ and Alloy $800 \mathrm{H}$. The protective nature of the oxide surface scales for these two materials in the prenxidized condition was studied and is believed to be related to the composition and formation characteristics of these scales.

Only modest differences in corrosion behavior were observed for the pickled, lapped, and grit-blasted specimens. This indicates that the corrosion kinetics are controlled by the availability of reactant gaseous impurities as npposed to lie mobility and near-surface activity of reactant solute constituents, such as chromium. 
THIS PAGE

\section{WAS INTENTIONALLY LEFT BLANK}


CONTENTS

ABSTRACT . . . . . . . . . . . . . . . . . .

1. INTRODUCTION ......................... . . . . 1

2. EXPERIMENTAL PROCEDURE . . . . . . . . . . . . . . 3

2.1. Test Specimens. . . . . . . . . . . . 3

2.2. Surface Preparation .............. 14

2.3. Controlled-Impurity Helium Exposure . . . . . . 26

2.4. Test Procedure . . . . . . . . . . . . 28

3. EXPERIMENTAL RESULTS . . . . . . . . . . . . . . . . 30

3.1. Weight Change . . . . . . . . . . . 30

3.2. Preoxidation Scale Formation . . . . . . . 38

3.3. Oxidation and Scale Formation ........... 47

3.4. Carburization ............... . . . 51

3.5. Bulk Carbon Content Analyses ........... 60

4. DISCUSSION ........................ 73

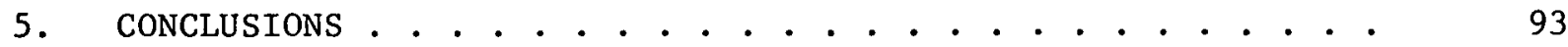

6. RECOMMENDATIONS FOR FUTURE WORK . . . . . . . . . . . . 95

7. ACKNOWLEDGMENTS . . . . . . . . . . . . . . . . . . . . . 96

8. REFERENCES ......................... 97

FIGURES

1. Typical microstructure observed in Alloy $800 \mathrm{H} \ldots \ldots 6$

2. Typical microstructure observed in Hastelloy $\mathrm{x} \ldots \ldots 7$

3. Typical microstructure observed in Inconel 617 . . . . . . 8

4. Typical microstructure observed in IN 100 ......... 9

5. Typical microstructure observed in IN 713LC . . . . . . . 10

6. Typical microstructure observed in HK 40 ......... 11

7. Typical microstructure observed in MA 754 . . . . . . . 12

8. Scanning electron micrograph showing typical surface condition for all alloys ................... 
9. Scanning electron micrographs showing the surface conditions after pickling treatments in a $\mathrm{HNO}_{3} / \mathrm{HF}$ solution for Alloy $800 \mathrm{H}$, Hastelloy $\mathrm{X}$, and Inconel $617^{3}$.............

10. Scanning electron micrographs showing the surface condition of MA 754 following a pickling treatment in a $\mathrm{HNO}_{3} / \mathrm{HF}$
solution . . . . . . . . . . . . . . .

11. Scanning electron micrographs showing the alumina grit used to perform the grit-blasting of test specimens . . . . . .

12. Scanning electron micrographs showing typical surface following a grit-blasting treatment on HK 40 and IN 713LC..

13. Scanning electron micrographs showing the surfaces of Inconel 617 and Alloy $800 \mathrm{H}$ following preoxidation treatments at $900^{\circ} \mathrm{C}$

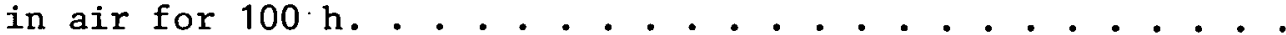

14. Scanning electron micrographs showing the surface of IN 100 following preoxidation treatments in air at $900^{\circ} \mathrm{C}$ for $1 \mathrm{~h}$, $10 \mathrm{~h}$, and $100 \mathrm{~h}$. . . . . . . . . ......

15. Scanning electron micrographs showing the surface condition of $\mathrm{HK} 40$ following a $100-\mathrm{h}$ preoxidation treatment at $900^{\circ} \mathrm{C}$ in air. . . . . . . . . . . . . . . . . . .

16. Scanning electron micrographs showing the surface of MA 754 following preoxidation treatments in air at $900^{\circ} \mathrm{C}$ for $1 \mathrm{~h}$,

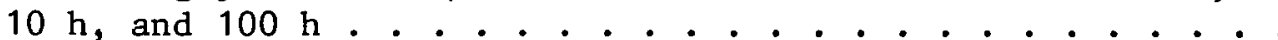

17. Schematic diagram of environment control system for parametric helium impurity corrosion study . . . . . . . . . . . . . .

18. Weight change as a function of exposure time for $\mathrm{Alloy} 800 \mathrm{H}$.

19. Weight change as a function of exposure time for Hastelloy $\mathrm{X}$. . . . . . . . . . . . . . . . . . . . 32

20. Weight change as a function of exposure time for Inconel 617.

21. Weight change as a function of exposure time for IN 100 . .

22. Weight change as a function of exposure time for IN 713LC . . 35

23. Weight change as a function of exposure time for $\mathrm{HK} 40$. . . 36

24. Weight change as a function of exposure time for MA 754 . . . 37

25. Surface oxide scales formed on Alloy $800 \mathrm{H}$ specimens . . . . . 39

26. Surface oxide scales formed on Hastelloy X specimens. . . . . 40

27. Surface oxide scales formed on Inconel 617 specimens. . . . . 41

28. Surface oxide scales formed on IN 100 specimens .. . . . . . . 42

29. Surface oxide scales formed on IN 713LC specimens . . . . . . . 43

30. Surface oxide scales formed on HK 40 specimens . . . . . . . 44

31. Surface oxide scales formed on MA 754 specimens . . . . . . . 45 
32. Surface scales formed on Alloy $800 \mathrm{H}$ specimens . . . . . . . . 48

33. Surface scales formed on Hastelloy X specimens . . . . . . . . 49

34. Surface scales formed on Inconel 617 specimens . . . . . . . . 50

35. Surface scales formed on IN 100 specimens . . . . . . . . . 52

36. Surface scales formed on IN 713LC specimens . . . . . . . . . 53

37. Surface scales formed on HK 40 specimens . . . . . . . . . . . 54

38. Surface scales formed on MA 754 specimens . . . . . . . . . . 55

39. Differential interference contrast photomicrographs showing Alloy $800 \mathrm{H}$ specimens, exposed $3000 \mathrm{~h}$ at $900^{\circ} \mathrm{C}$ in controlledimpurity helium . . . . . . . . . . . . . . . . . .

40. Differential interference contrast photomicrographs showing Hastelloy $\mathrm{X}$ specimens exposed $3000 \mathrm{~h}$ at $900^{\circ} \mathrm{C}$ in controlledimpurity helium . . . . . . . . . . . . . . . . . . .

41. Differential interference contrast photomicrographs showing Inconel 617 specimens exposed $3000 \mathrm{~h}$ at $900^{\circ} \mathrm{C}$ in controlledimpurity helium .. . . . . . . . . . . . . . .

42. Differential interference contrast photomicrographs showing IN 100 specimens exposed $3000 \mathrm{~h}$ at $900^{\circ} \mathrm{C}$ in controlledimpurity helium . . . . . . . . . . . . . . . . . . .

43. Differential interference contrast photomicrographs showing IN $713 \mathrm{LC}$ specimens exposed $3000 \mathrm{~h}$ at $900^{\circ} \mathrm{C}$ in controlledimpurity helium . . . . . . . . . . . . . . . .

44. Differential interference contrast photomicrographs showing HK 40 and MA 754 specimens exposed $3000 \mathrm{~h}$ at $900^{\circ} \mathrm{C}$ in controlled-impurity helium . . . . . . . . . . . .

45. Bulk carbun concentrations for Alloy $800 \mathrm{H}$ specimens . . . .. 64

46. Bulk carbon concentrations for Hastelloy X specimens . . . . 65

4\%. Bulk carbun concentrationc for Inconel 617 specimens . . . . 66

48. Bulk carbon concentrations for IN 100 specimens . . . . . . . 67

49. Bulk carbon concentrations for IN 713LC specimens . . . . . 68

50. Bulk carbon concentrations for HK 40 specimens . . . . . . . 69

51. Bulk carbon concentrations for MA 754 specimens . . . . . . . 70

52. Scanning electron micrographs showing surface scales formed nn Alloy $800 \mathrm{H}$ preoxidized $1 \mathrm{~h}$. . . . . . . . . . . . . 76

53. Scanning electron micrographs showing surface scales formed on Alloy $800 \mathrm{H}$ preoxidized $10 \mathrm{~h}$. . . . . . . . . . . .

54. Scanning electron micrographs showing surface scales formed on Alloy $800 \mathrm{H}$ preoxidized $100 \mathrm{~h}$. . . . . . . . . . . : 
55. Scanning electron micrographs showing surface scales formed on Hastelloy $\mathrm{X}$ preoxidized $1 \mathrm{~h}$. . . . . . . . . ........

56. Scanning electron micrographs showing surface scales formed on Hastelloy $\mathrm{X}$ preoxidized $10 \mathrm{~h}$. . . . . . . . . . . . .

57. Scanning electron micrographs showing surface scales formed on Hastelloy X preoxidized $100 \mathrm{~h}$. . . . . . . . . . . . . . .

58. Corrosion characteristics of preoxidized Alloy $800 \mathrm{H}$. . . . . 85

59. Corrosion characteristics of preoxidized Hastelloy X . . . . . 86

60. Corrosion characteristics of preoxidized Inconel 617 . . . . . 87

61. Corrosion characteristics of preoxidized IN 100 . . . . . . . 88

62. Corrosion characteristics of preoxidized IN 713LC . . . . . . . 89

63. Corrosion characteristics of preoxidized HK 40 . . . . . . . . 90

64. Corrosion characteristics of preoxidized MA 754 . . . . . . . 91

\section{TABLES}

1. Test matrix - effects of surface treatment on the corrosion of structural materials in a simulated HTGR-GT environment

2. Chemical composition of test alloy systems . . . . . . . . 5

3. Corrosion behavior after $3000 \mathrm{~h}$ exposures to a controlled-impurity helium environment . . . . . . . . . . . .

4. Concentrations of metallic elements observed in oxide surface scales formed on Hastelloy $X$ and Alloy 80011 for preoxidized and HTGR-GT exposure conditions. . . . . . . . . . . . . 


\section{INTRODUCTION}

It is currently well known that the practical limitations to impurity control in high-temperature gas-cooled reactor (HTGR) helium coolant gas lead to a coolant that contains small but measureable concentrations of oxidizing and carburizing impurity species (Refs. 1-5). While the utilization of helium as a coolant provides several key advantages over other coolants (Ref.6), the presence of these impurities makes a thorough understanding of their effects on the system a necessity.

The impurities include $\mathrm{CO}, \mathrm{CO}_{2}, \mathrm{CH}_{4}, \mathrm{H}_{2}$, and $\mathrm{H}_{2} \mathrm{O}$. The effects of these impurities are being studied in numerous corrosion programs, both at General Atomic Company (GA) (Ref. 1) and at other laboratories (Refs. 7. 8). The interactions of these impurities and candidate metallic structural materials indicate that carburization is the most serious corrosion mechanism. The maximum operating temperature of HTGR components may be limited by alloy carburization and the associated degradation in mechanical properties.

Carburization leads to the near-surface precipitation of intergranular and intragranular carbides, which results in substantial reductlons in creep and short-time tensile ductilities for some of the candidate alloys (Refs. 1-3, 9). In addition, the depletion of solid solution strengthening solute species through these precipitation reactions can affect creep etrength and reduce creep lifetimes.

Surface finish has been shown to be an important parameter in the high-temperature corrosion of alloys in other industrial applications (Refs. 10, 11). Enhancement of corrosion resistance can be achieved with proper control of the initial surface, which affects diffusion rates, elemental constituent activities, and near-surface chemical composition. 
These factors influence the kinetics by which reactions can occur. 'Another common practice in controlling elevated-temperature corrosion is to utilize coatings, thereby either reducing or: eliminating environment-substrate interactions.

This report describes the effects of prior surface treatment on the subsequent controlled-impurity helium corrosion observed for several key candidate alloys. Another report, which will be prepared at a later date; will cover the effects of various machined and ground surface conditions. The alloys tested include cast superalloys, a centrifugally cast hightemperature alloy, an oxide-dispersion-strengthened alloy, and several wrought high-temperature alloys. 


\section{EXPERIMENTAL PROCEDURE}

Table 1 shows the test matrix that was adopted to study surface finish condition effects in a simulated gas turbine (GT) HTGR environment. Included are typical industrial practices such as pickling and gritblasting, as well as finish preparation techniques that may appear to be more laboratury related, e.g., lapping. Also included are preoxidation treatments in air, which result in the formation of oxide surface scales and can be viewed as a simplistic coating application procedure. This report presents the results of the Phase I, Run 1 exposures.

\subsection{TEST SPECIMENS}

Test alloy selection was made to include promising alloy systems from various categories of presently available commercial materials. In the as-cast forms there are two cast superalloys (IN 100 and IN 713LC) and one centrifugally cast high-temperature alloy (HK 40). Three wrought high-temperature alloys (Alloy $800 \mathrm{H}$, Inconel Alloy 617, and Hastelloy Alloy $X)$, representing widely used tubing and piping materials, were also included. Finally, an iron-base oxide-dispersion-strengthened material (Inconel MA 754) was also tested. Table 2 gives the chemical compositions, heat numbers, and as-recelved conditions of the materials tested. In the case of $\mathrm{HK} 40$, a remnant piece of cast tube was used to machine specimens and it was not possible to determine the heat number; therefore, the GA code number of the heat is given instead.

Figures 1 through 7 show the typical microstructures observed in the test alloys. Both longitudinal and transverse sections are shown to illustrate important microstructural characteristics and the effects of processing on the texture observed in the materiais. 
TA.3LE 1

TEST MATRIX - EFFECTS OF SURFACE TREATMENT ON THE CORROSION OF STRUCTURAL MATERIALS IN A SIMULATED HTGR-GT ENVIRONRIENT.(a) PHASE 1 - RUN $1\left(900^{\circ} \mathrm{C}, 3000 \mathrm{~h}\right)$.

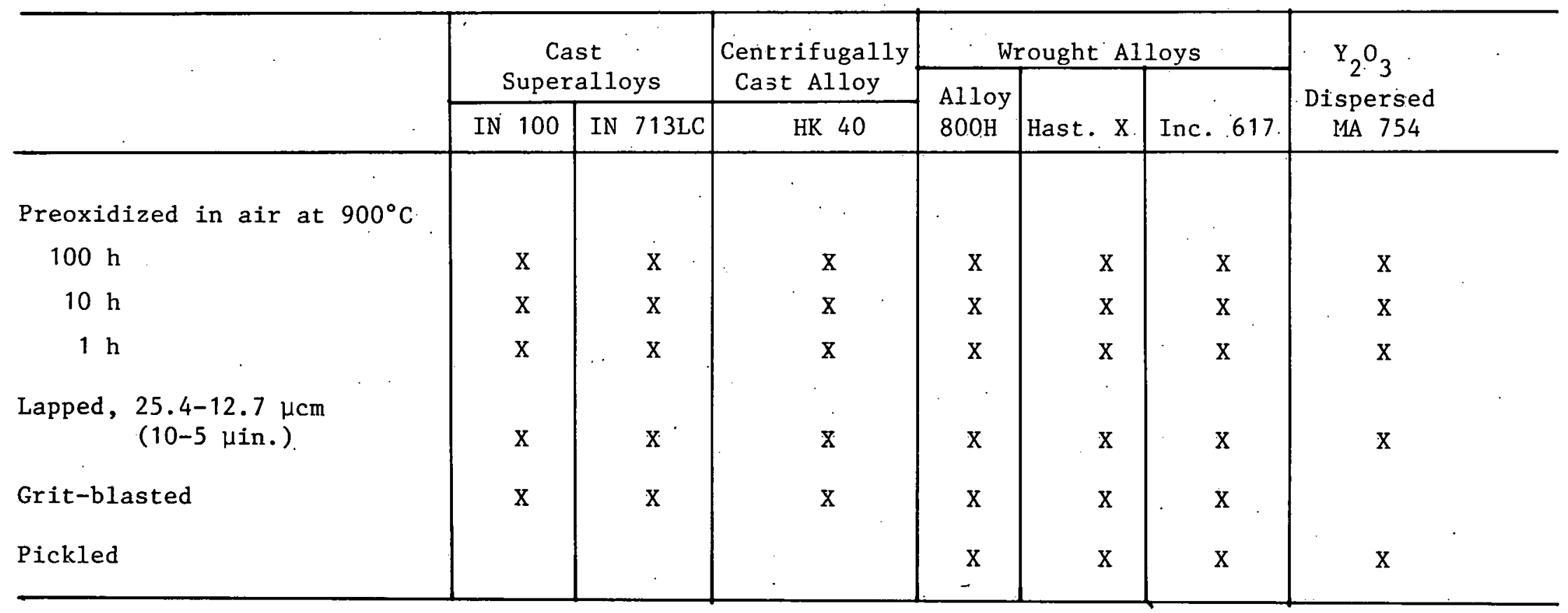

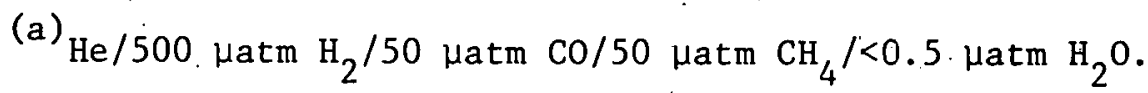


TABLE 2

CHEMICAL COMPOSITION OF TEST ALLOY SYSTEMS (VENDOR VALUES)

\begin{tabular}{|c|c|c|c|c|c|c|c|c|c|c|c|c|c|c|c|c|c|c|c|c|}
\hline \multirow{2}{*}{$\begin{array}{c}\text { Alloy } \\
\text { (Heat) } \\
\text { As-Received Condition }\end{array}$} & \multicolumn{20}{|c|}{ Composition (wt \%) } \\
\hline & c & $\mathrm{Ni}$ & $\mathrm{Fe}$ & $\mathrm{Cr}$ & Mn & $\mathrm{Si}$ & Mo & Co & W & $\mathrm{Nb}$ & $\mathrm{Ta}$ & A.1 & $\mathrm{Ti}$ & $\mathrm{Cu}$ & $\mathrm{v}$ & $\mathrm{Zr}$ & B & $\mathrm{P}$ & $\mathrm{s}$ & $\mathrm{Y}_{2} \mathrm{O}_{3}$ \\
\hline $\begin{array}{l}\text { Haste1loy A1loy X } \\
(126007437) \\
\text { Solution-annealed }\end{array}$ & 0.07 & Bal. & 18.97 & 22.06 & 0.6 & 0.44 & 8.79 & 1.69 & 0.67 & -- & -- & -- & -- & -- & -- & -- & 0.002 & 0.02 & $<0.002$ & -- \\
\hline $\begin{array}{l}\text { Incone: Alloy } 617 \\
\text { (xX14^6LK) } \\
\text { Solution-annealed }\end{array}$ & 0.06 & 55.13 & 0.53 & 21.74 & 0.02 & 0.10 & 8.91 & 12.32 & -- & -- & -- & 1.11 & 0.30 & 0.11 & -- & -- & 0.003 & -- & 0.002 & -- \\
\hline $\begin{array}{l}\text { Alloy } 800 \mathrm{H} \\
\text { (HH8099A) } \\
\text { Solution-annealed }\end{array}$ & 0.67 & 32.03 & 45.50 & 19.79 & 1.00 & 0.18 & -- & -- & -- & -- & -- & 0.38 & 0.45 & 0.60 & -- & -- & -- & -- & 0.003 & -- \\
\hline $\begin{array}{l}\text { HK } 40 \\
(\text { G } 321 \text { ) (a) } \\
\text { As centrifugally cast }\end{array}$ & $0 . \angle 1$ & 20.1 & Bal. & 25.3 & 0.33 & 1.23 & -- & -- & -- & -- & -- & - & -- & -- & -- & -- & -- & -- & -- & -- \\
\hline $\begin{array}{l}\text { IN } 100 \\
\text { (UA0457111047) } \\
\text { is-cast }\end{array}$ & 0.8 & Bal. & 0.20 & 9.85 & $<0.10$ & $<0.10$ & 3.03 & 15.18 & -- & -- & -- & 5.46 & 4.19 & -- & 1.05 & 0.07 & 0.015 & -- & 0.0016 & -- \\
\hline $\begin{array}{l}\text { IN } 713: \text { C } \\
\text { (WA39856E6965) } \\
\text { As-cast }\end{array}$ & 0.06 & Bal. & 0.15 & 12.00 & $<0.10$ & $<0.10$ & 4.10 & 0.10 & -- & $\stackrel{2}{2}$ & & 5.85 & 0.71 & $<0.10$ & -- & 0.06 & 0.007 & 0.002 & 0.0015 & -- \\
\hline $\begin{array}{l}\text { Inconel MA } 754 \\
\text { (DT02A BB 1-2) } \\
\text { Mechanically alloyed }\end{array}$ & 0.07 & 76.11 & 1.52 & 20.68 & -- & -- & -- & -- & -- & -- & -- & 0.30 & 0.40 & -- & -- & -- & -- & -- & 0.003 & 0.58 \\
\hline
\end{tabular}

(a) General Atomic code number. 

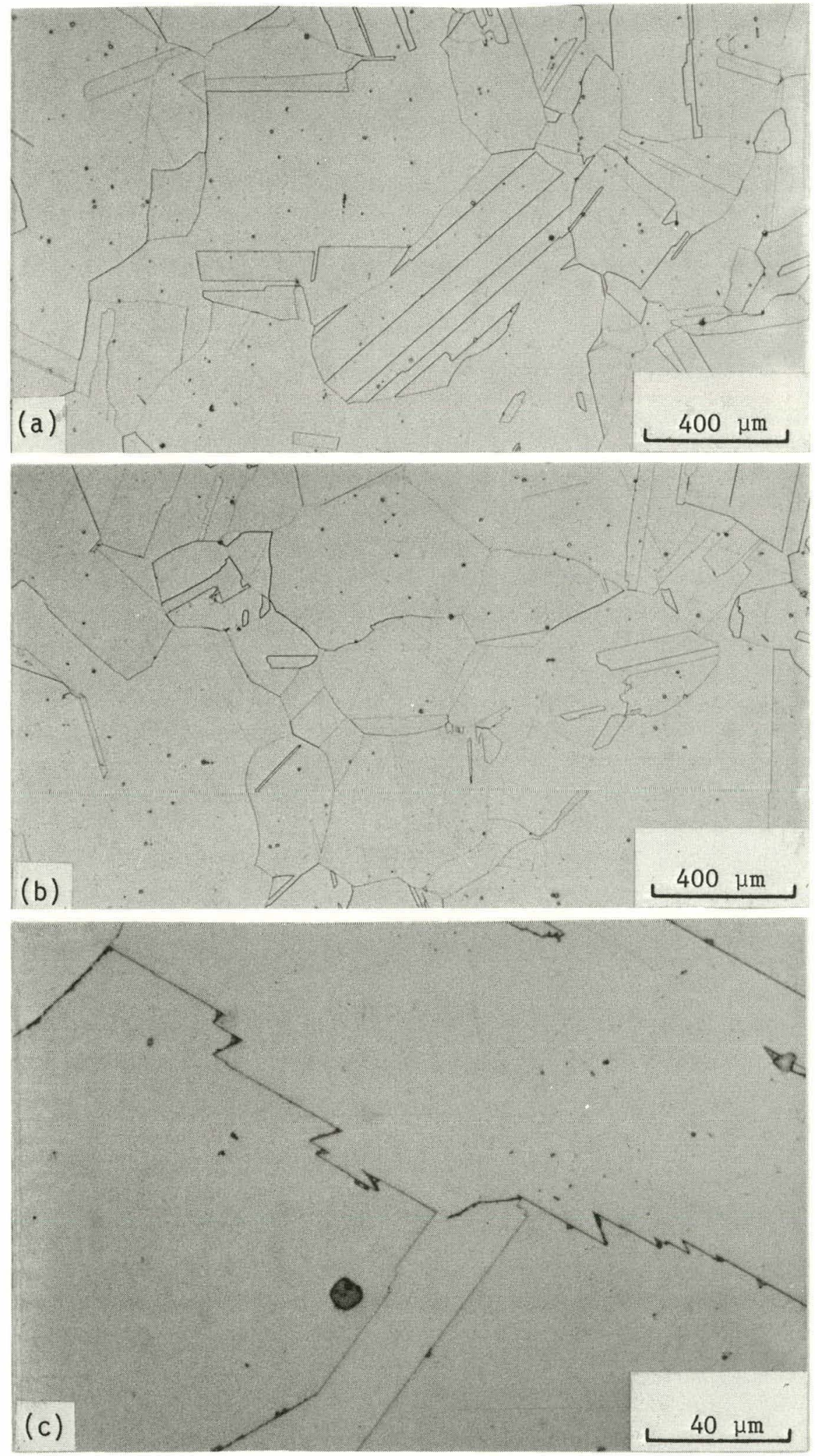

Fig. 1. Typical microstructure observed in Alloy 800H, heat HH8099A: (a) transverse, (b, c) longitudinal 

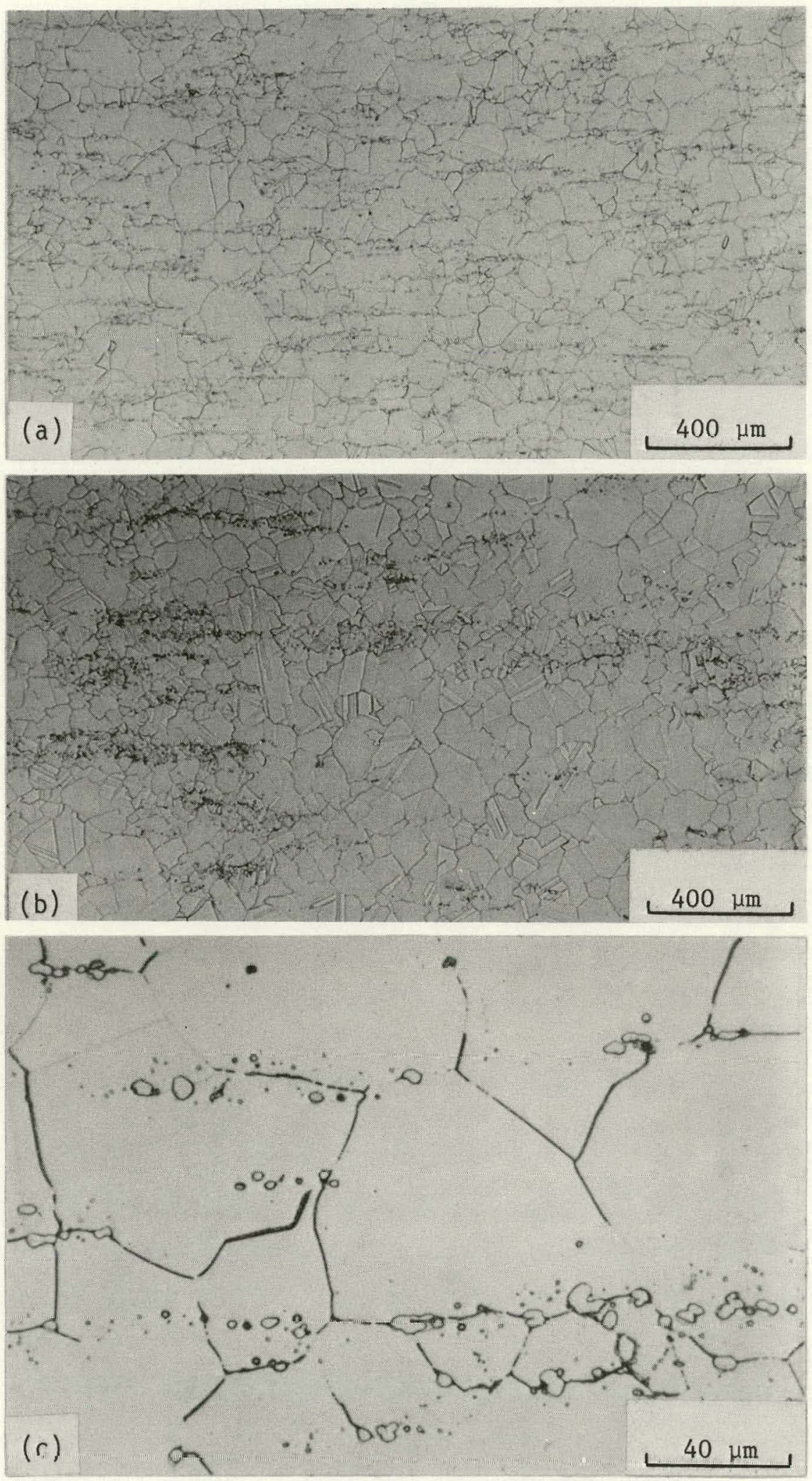

Fig. 2. Typical microstructure observed in Hastelloy X, heat 1260074737: $(a, c)$ transverse, (b) longitudinal 

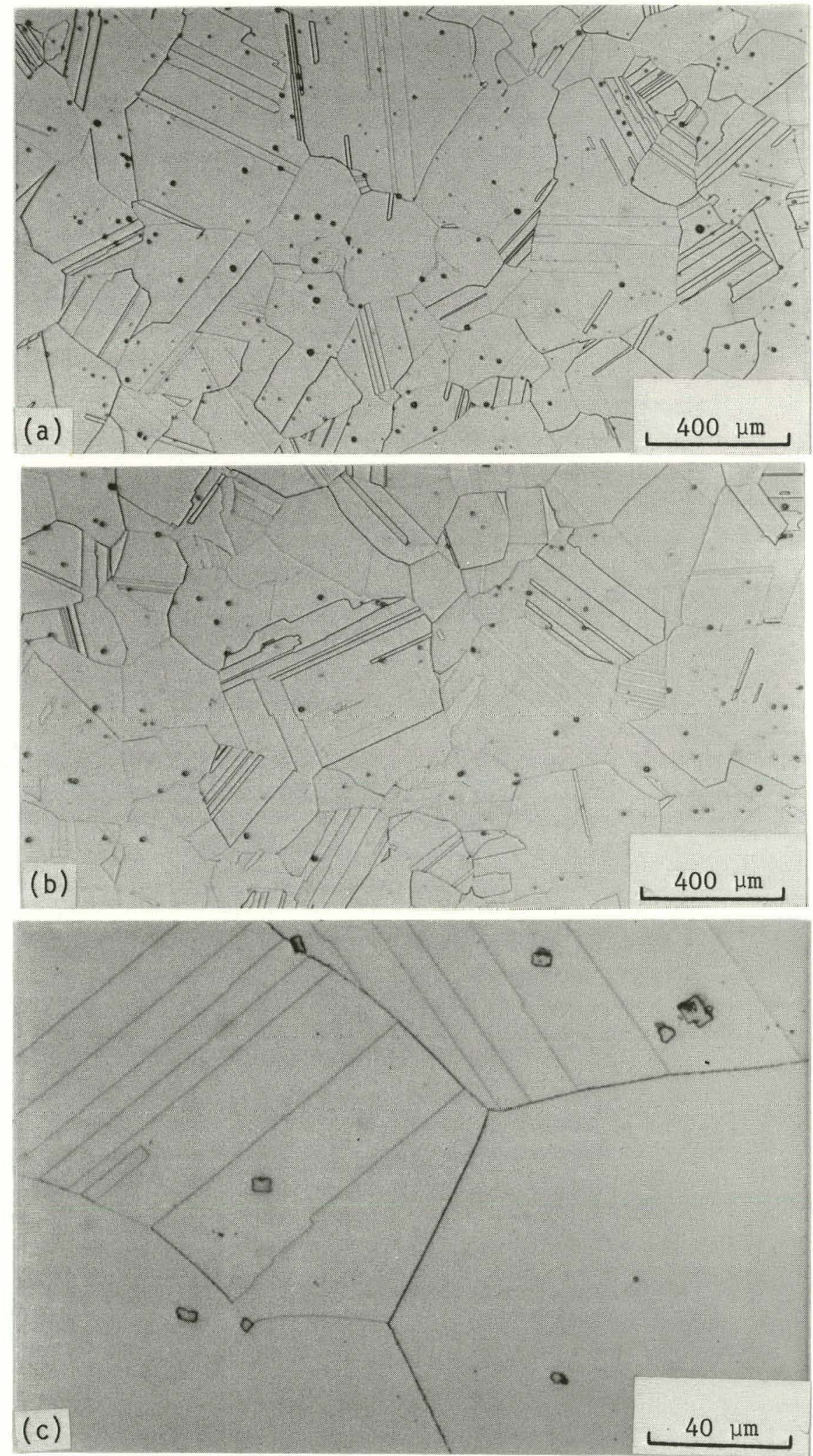

Fig. 3. Typical microstructure observed in Incone1 617, heat XX14A6UK: (a, c) transverse, (b) longitudinal 

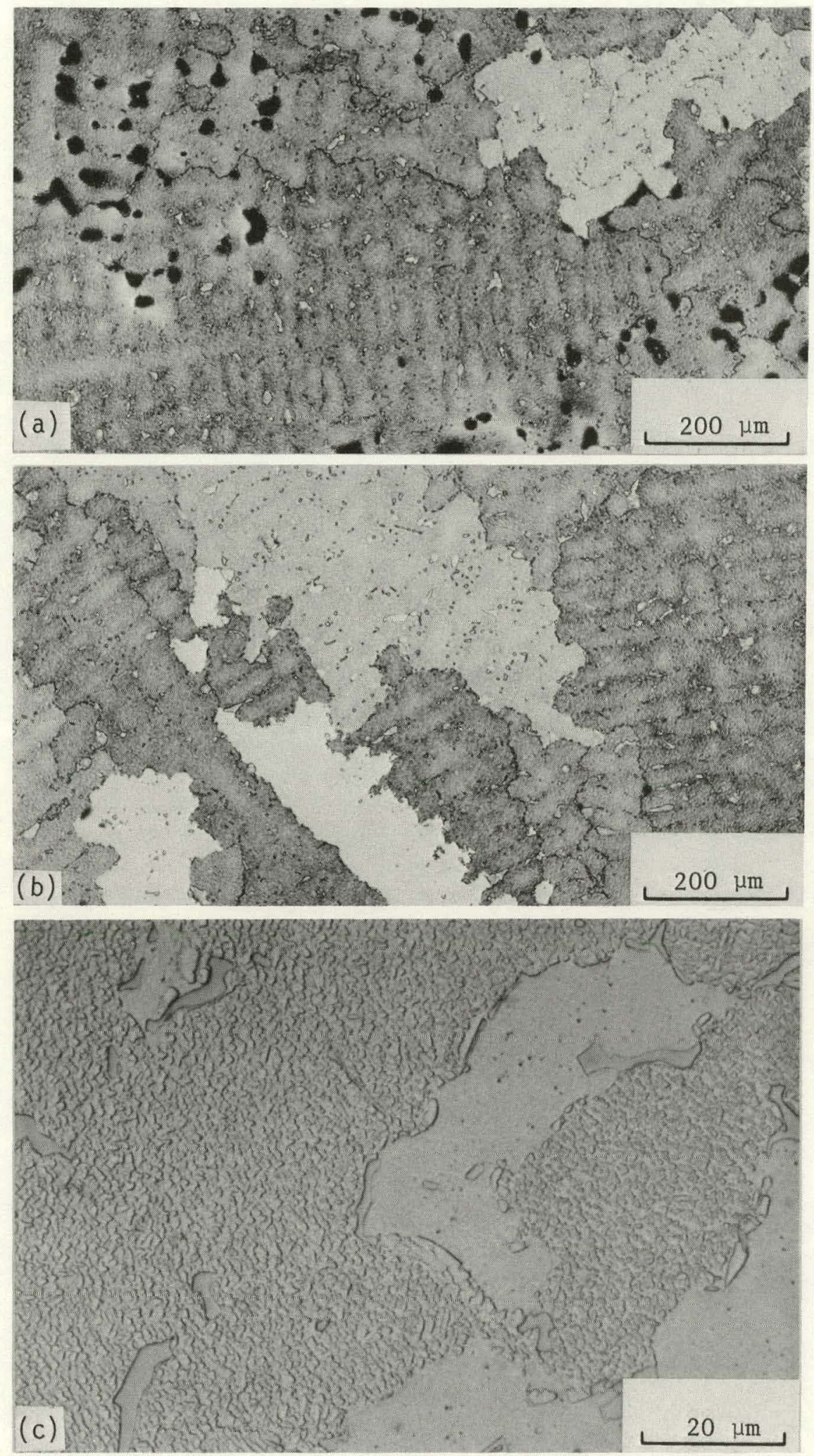

'ig. 4. Typical microstructure observed in IN 100, heat UA45 (711047): (a, c) 1ongitudina1, (b) transverse 

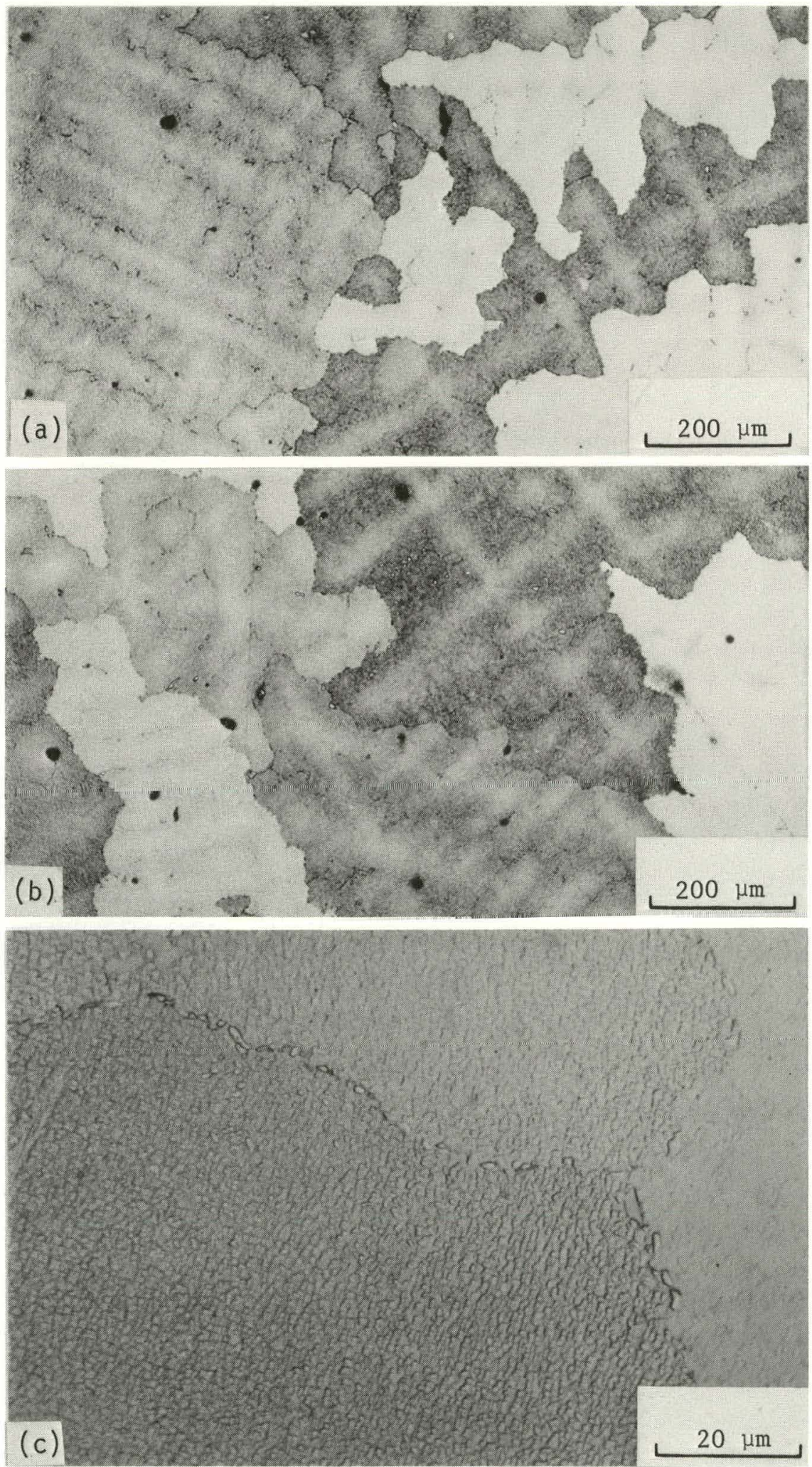

Fig. 5. Typical microstructure observed in IN 713LC, heat WA398 (66B6965): (a) transverse, (b, c) longitudinal 

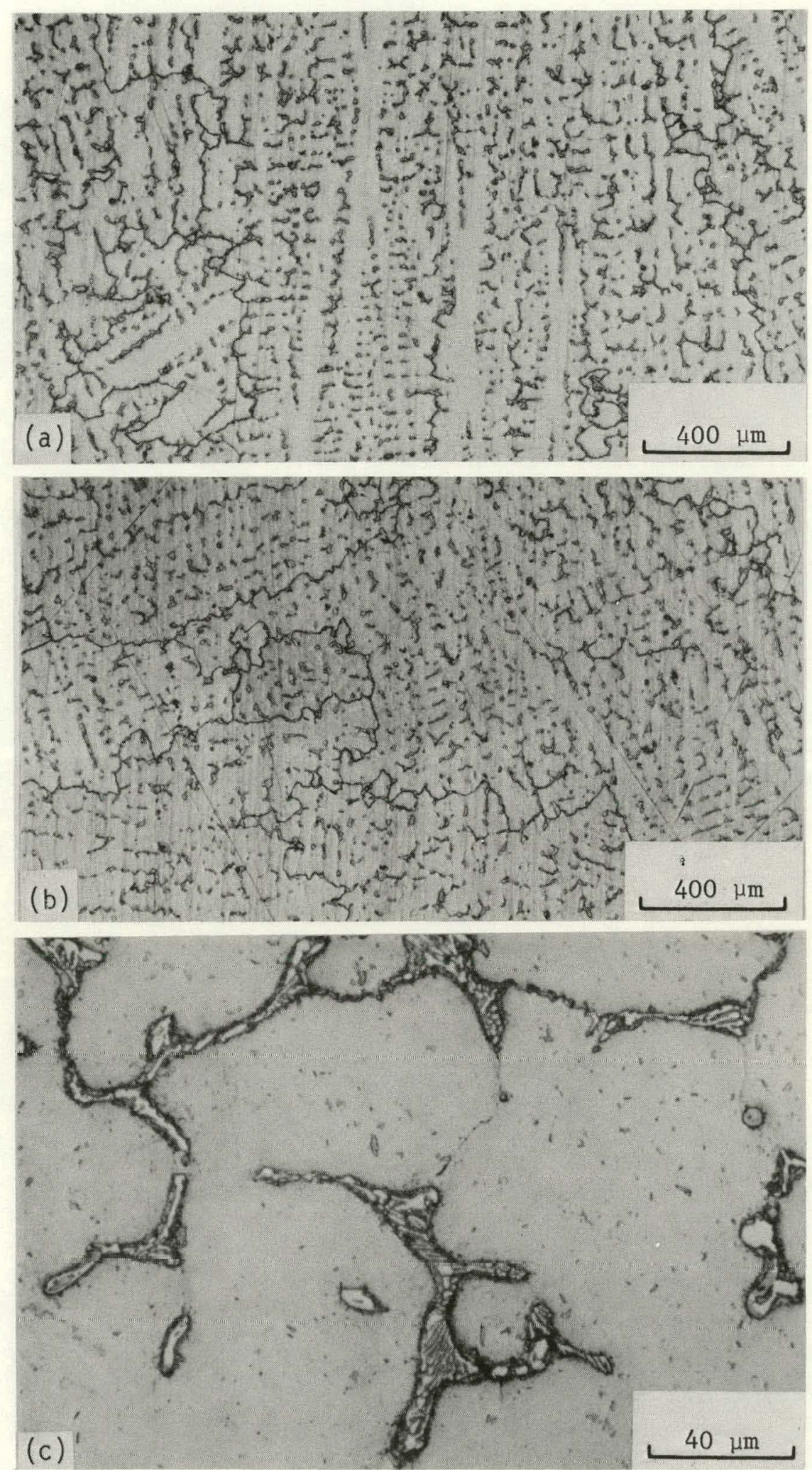

Fig. 6. Typical microstructure observed in HK 40, heat GA321: (a) transverse, (b, c) longitudinal 


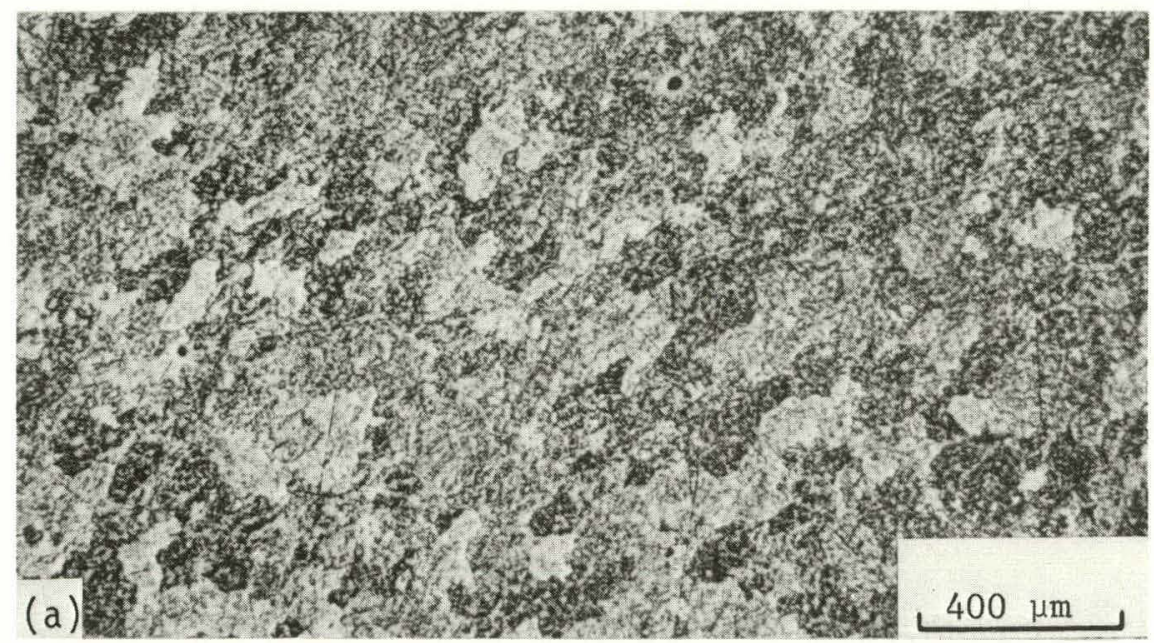
W67.

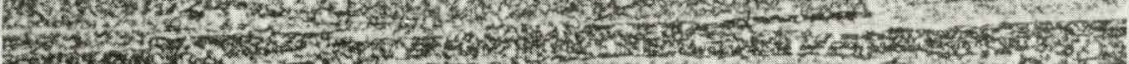

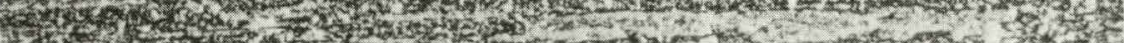

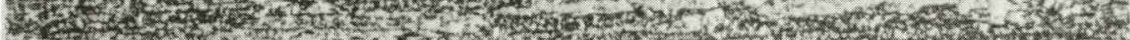

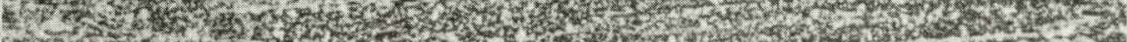

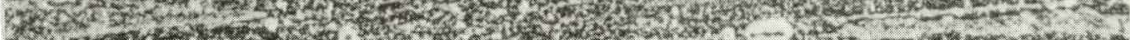

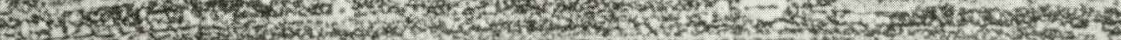

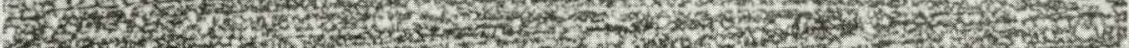

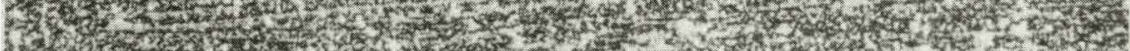

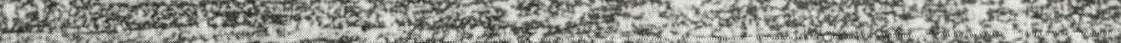

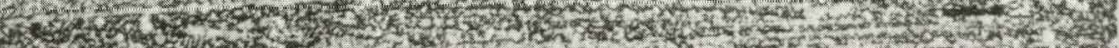

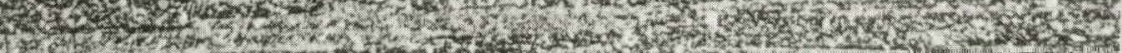

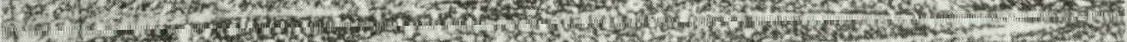

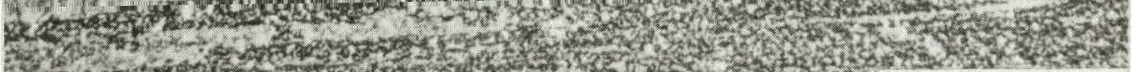

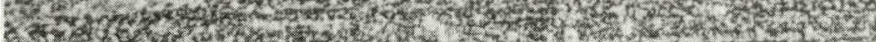

(b)

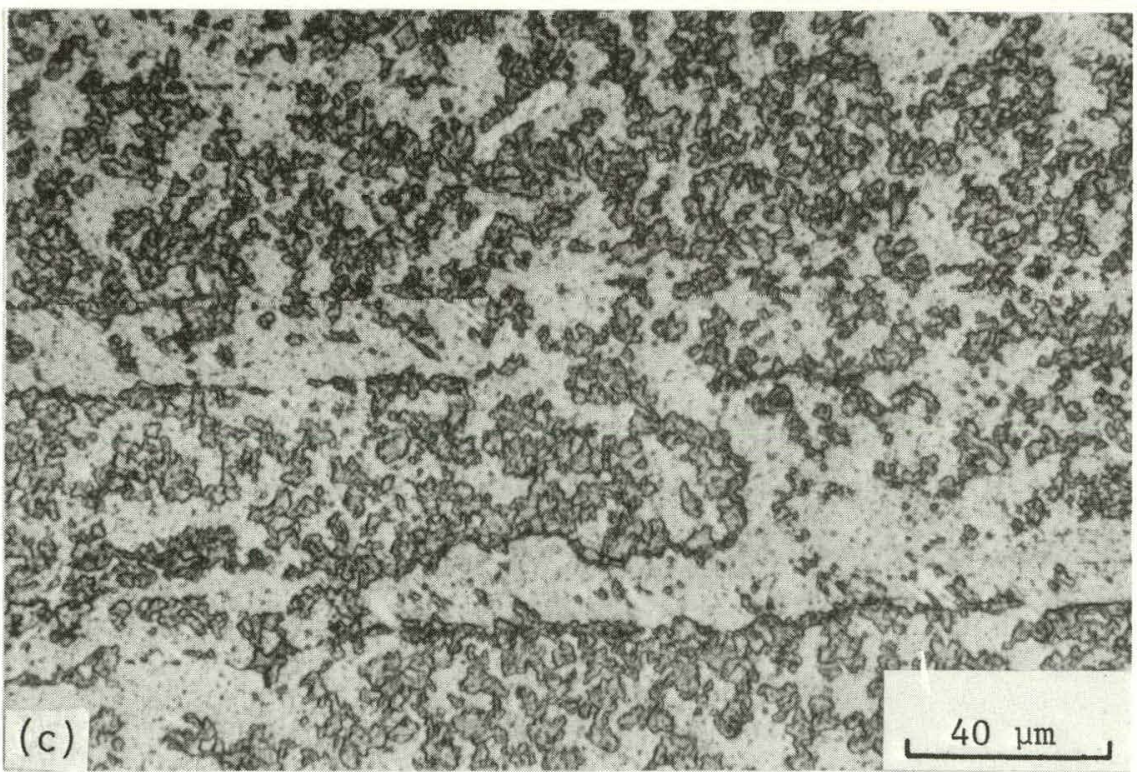

Fig. 7. Typical microstructure observed in MA 754, heat DT0 2A8 B1-2: (a) transverse, (b, c) 1ongitudina1 
In Figs. 1 through 3, the microstructures of the wrought hightemperature alloys show virtually no texture effect between the longitudinal and transverse sections. This is generally true of wrought materials and is associated with the solution-annealing processing step (following any mechanical rolling), which tends to produce an equiaxed microstructure. Figure 1 shows the typical solution-annealed microstructure for Alloy $800 \mathrm{H}$ with blocky titanium carbonitride and finer $\mathrm{M}_{23} \mathrm{C}_{6}$ carbide precipitates (Ref. 12) and having a grain size in the range of 200 to $400 \mu \mathrm{m}$. In Fig. 2 the microstructure of Hastelloy $X$ is shown to be much finer grained (30 to $150 \mu \mathrm{m})$ with carbide stringers present throughout the microstructure. These carbides have been determined to be ${ }_{6} \mathrm{C}$ variants and are generally of a smaller lattice parameter than the $\mathrm{M}_{6} \mathrm{C}^{\prime}$ carbides that form with thermal aging (Refs. 9, 13, 14). Figure 3 shows the microstructure of Inconel 617, which tends to be of a larger grain size (200 to $400 \mu \mathrm{m}$ ) and in this heat is heavily twinned. Similar to Alloy $800 \mathrm{H}$, Inconel 617 contains carbonitrides and $\mathrm{M}_{23} \mathrm{C}_{6}$ carbides in the solution-annealed condition.

Figures 4 and 5 show the microstructures observed for the cast superalloys IN 100 and IN 713LC, respectively. Typical of these materials, dendritic structures with a heavy density of $\mathrm{Ni}_{3}(\mathrm{Al}, \mathrm{Ti})$ precipitates were observed (Ref. 15). Also apparent is the higher density of casting defects, i.e., shrinkage pores, present in this casting of IN 100 in comparison with the IN 713LC. The microstructures in these cases represent the as-cast condition for these materials.

Figure 6 shows the as-cast microstructure of HK 40, a centrifugally cast high-temperature alloy. The high carbon concentration ( 0.41 wt \%) in the alloy leads to the grain-boundary and interdendritic precipitation of primary eutectic carbides upon solidification (Ref. 16).

Figure 7 shows the microstructure of the oxide-dispersion-strengthened nickel-base alloy, MA 754. In this case, the base alloy, which is essentially $80 \mathrm{Ni}-20 \mathrm{Cr}$, is mechanically alloyed with yttria dispersoids, leading to a heavily textured microstructure and a dramatic difference in longitudinal and transverse mechanical behavior (Ref. 17). 


\subsection{SURFACE PREPARATION}

The specimens to be exposed in the simulated HTGR-GT environment were carefully prepared to give surfaces typical of the following treatments: (1) lapping, (2) pickling, (3) grit-blasting, and (4) preoxidizing. The methodology used to prepare the specimens was always that which was most consistent with laboratory or industrial practices, depending upon the specific treatment.

Al1 corrosion test specimens were in the form of 6.35-mm (0.25-in.) diameter by $25.4-\mathrm{mm}$ (1.00-in.) long cylinders with a centrally located 3.17-mm (0.125-in.) diameter hole drilled near one end for positioning in the specimen holder.

Specimens of the cast superalloys, IN 100 and IN 713LC, were sliced from 6.35-mm (0.25-in.) diameter by 76.2-mm (3.00-in.) long as-cast bars. These specimens were grit-blasted at the foundry with 90 to 120 mesh alumina, which is typical of cast turbine components. Surface preparation of these two alloys was performed with the specimens in the gritblasted initial condition.

The wrought, oxide-dispersion-strengthened, and centrifugally cast alloy specimens were machined from bar stock, flat stock, and longitudinally cut blanks, respectively, resulting in a uniform surface finish of 8 to $16 \mathrm{rms}$. Any surface preparation for these alloys was performed with the specimen in this initial condition.

Lapping was performed by mounting the end of the specimen in an electric drill and polishing with a canvas cloth and 3- $\mu \mathrm{m}$ diamond paste. This procedure produced specimens with a consistent finish regardless of specimen composition. Figure 8 shows a typical lapped surface, with only very fine scratches present.

The pickling procedure used involved a two-step treatment similar to that employed in many steel mills. The specimens were descaled using 


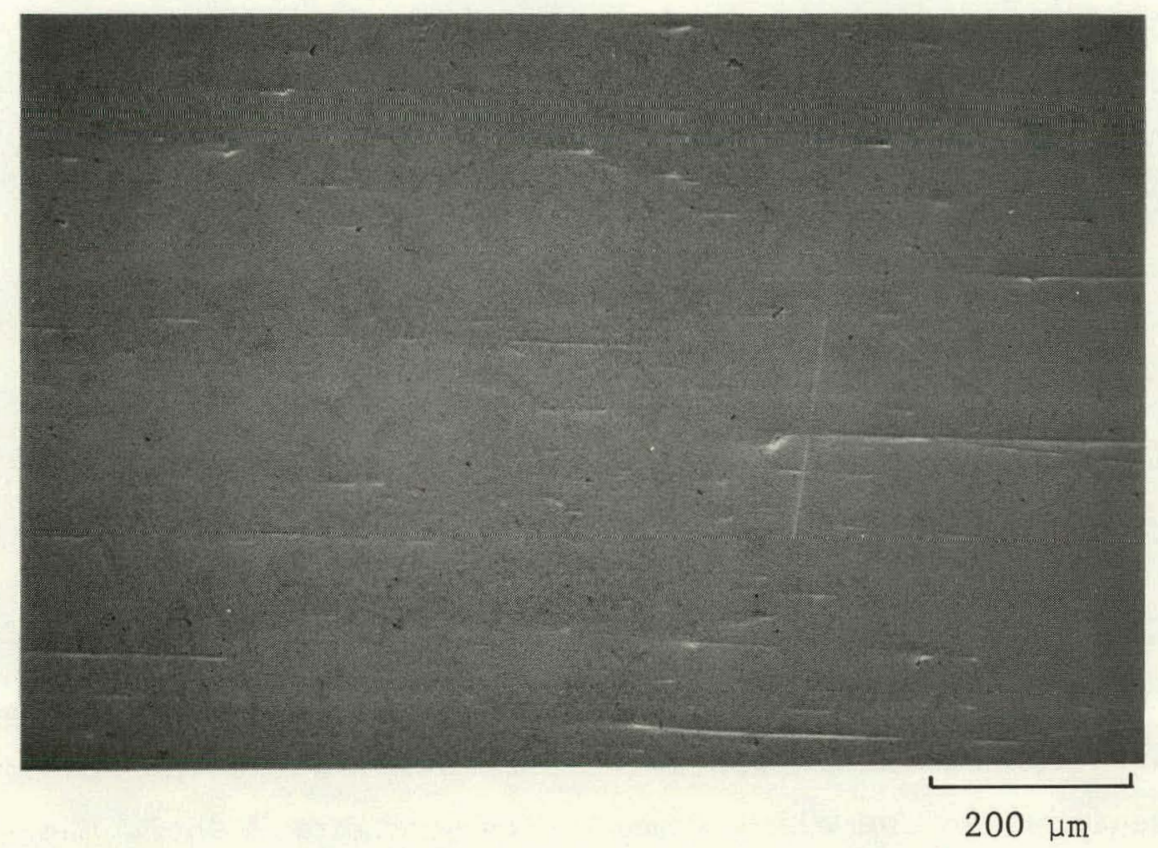

Fig. 8. Scanning electron micrograph showing typical surface condition for al1 alloys (HK 40 shown) following a lapping treatment 
the procedure listed below.

2-h immersion at $82^{\circ} \mathrm{C}\left(180^{\circ} \mathrm{F}\right)$ in a solution consisting of :

Potassium permanganate: $3 \%$ by volume

Sodium hydroxide: $18 \%$ by volume

Balance $\mathrm{H}_{2} \mathrm{O}$

Following the descaling treatment, the specimens were pickled using the procedure listed below.

$20-$ min immersion at $60^{\circ} \mathrm{C}\left(140^{\circ} \mathrm{F}\right)$ in a solution consisting of :

Nitric acid: $15 \%$ by volume

Hydroflouric acid: $2 \%$ by volume

Balance $\mathrm{H}_{2} \mathrm{O}$

The cast materials were not pickled since this particular procedure is not applicable to these materials. The pickling treatment produced finishes that were dependent upon al1ny chemistry, oince the solutiuu reactivity depended on the alloy composition. Figure 9 shows the surfaces produced on the wrought alloys. Alloy $800 \mathrm{H}$ tended to etch, whereas Hastelloy $\mathrm{X}$ was more immune and attack was enhanced at $\mathrm{M}_{6} \mathrm{C} /$ matrix interfaces leaving holes on the surface where carbides fell out as the surrounding matrix dissolved. Inconel 617 was even more resistant to attack, as shown in Fig. 9c. Figure 10 shows the surface produced on MA 754, where orientational effects can be noted. In Fig. 10a, the areas where preferential attack occurred are pitted in comparison with adjacent areas where little chemical attack is apparent. Figure $10 \mathrm{~b}$ shows an area where attack was pronounced. Again the attack was greatest at particle/matrix interfaces, in this case at the interfaces of the yttria dispersoids and the alloy matrix. A close examination reveals some of the yttria particles although they are very small relative to the "holes" at the surface.

Grit-blasting was performed on all specimens using either 100 or 220 mesh alumina grit. Figure 11 shows the two types of grit used for this purpose. Surfaces of all grit-blasted test specimens were quite uniform and very similar; typical examples are shown in Fig. 12. It is 


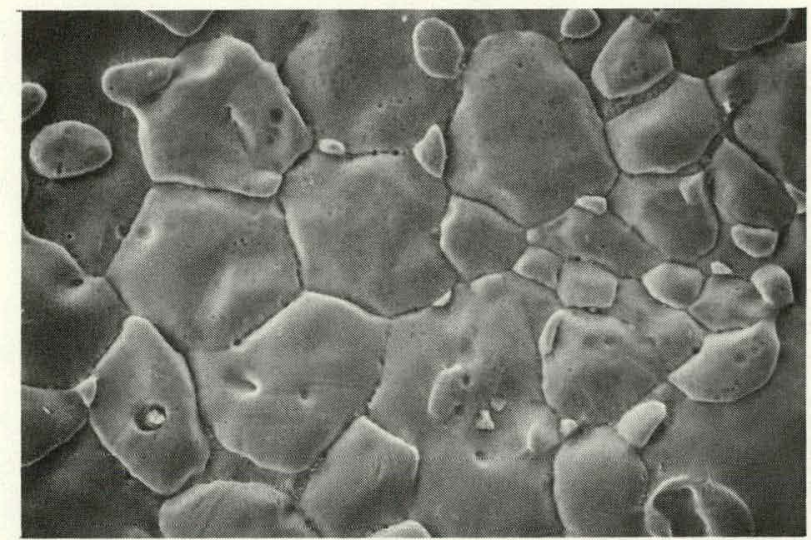

(a)

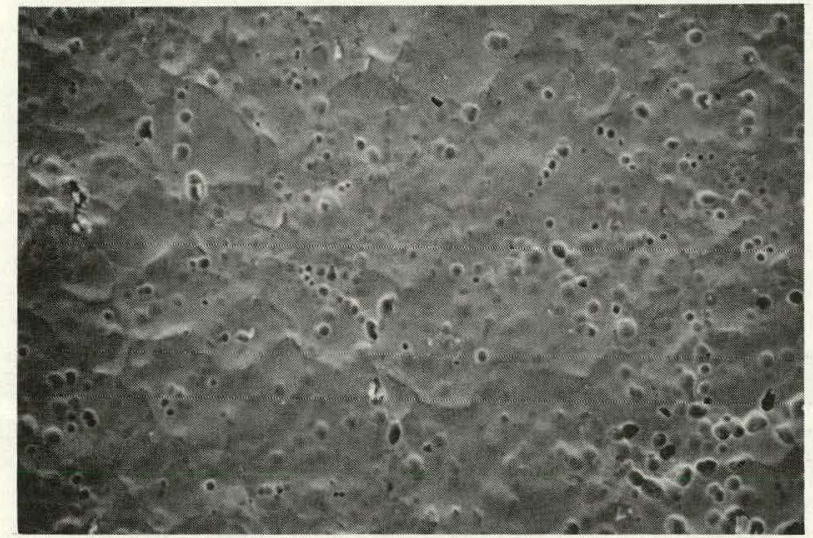

(b)

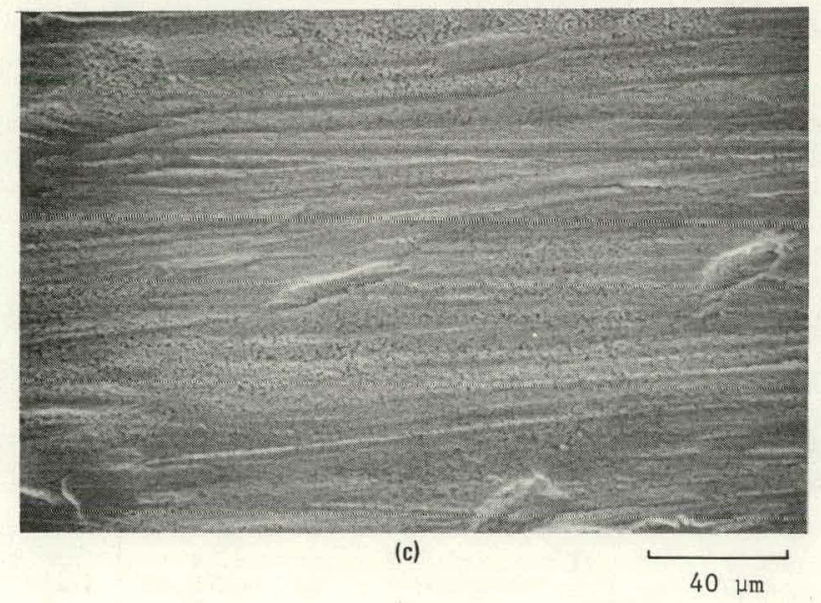

Fig. 9. Scanning electron mirrographs showing the surface conditions after pickling treatments in a $\mathrm{HNO}_{3} / \mathrm{HF}$ solution for (a) Alloy $800 \mathrm{H}$, (b) Hastelloy $\mathrm{X}$, and (c) Inconel 617 

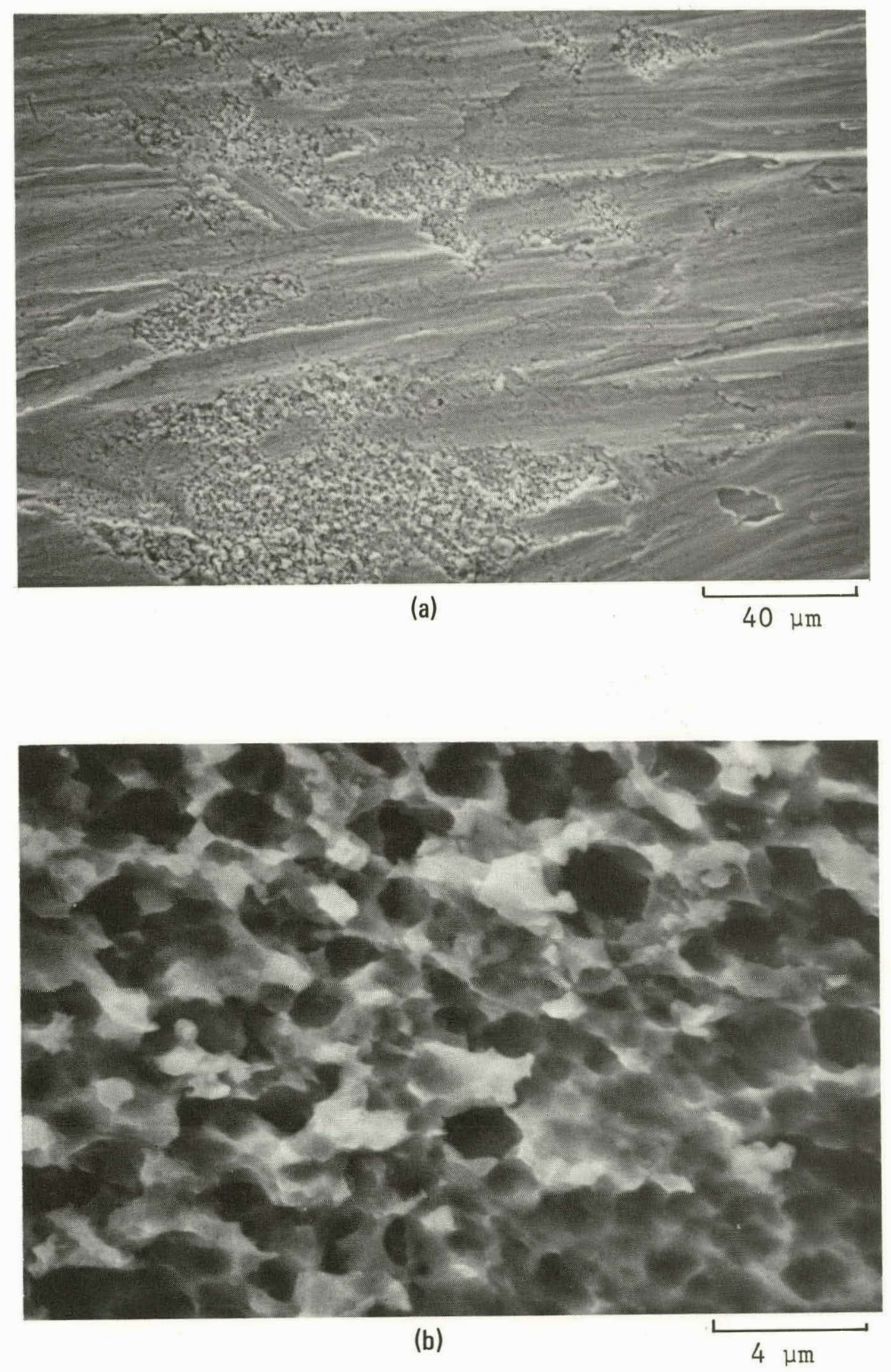

Fig. 10. Scanning electron micrographs showing the surface condition of MA 754 following a pickling treatment in a $\mathrm{HNO}_{3} / \mathrm{HF}$ solution 

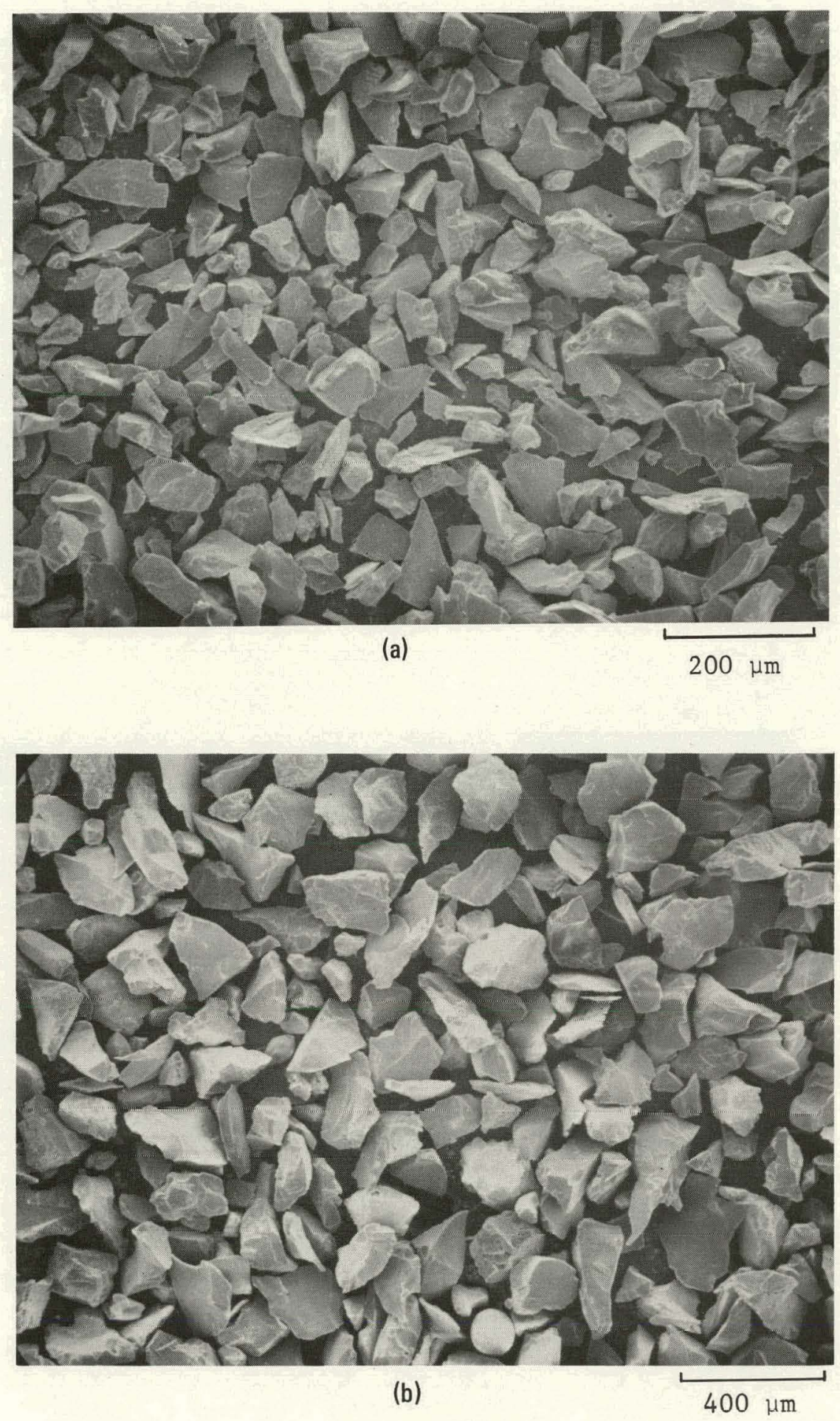

Fig. 11. Scanning electron micrographs showing the alumina grit used to perform the grit-blasting of test specimens: (a) No. 220 grit and (b) No. 100 grit 

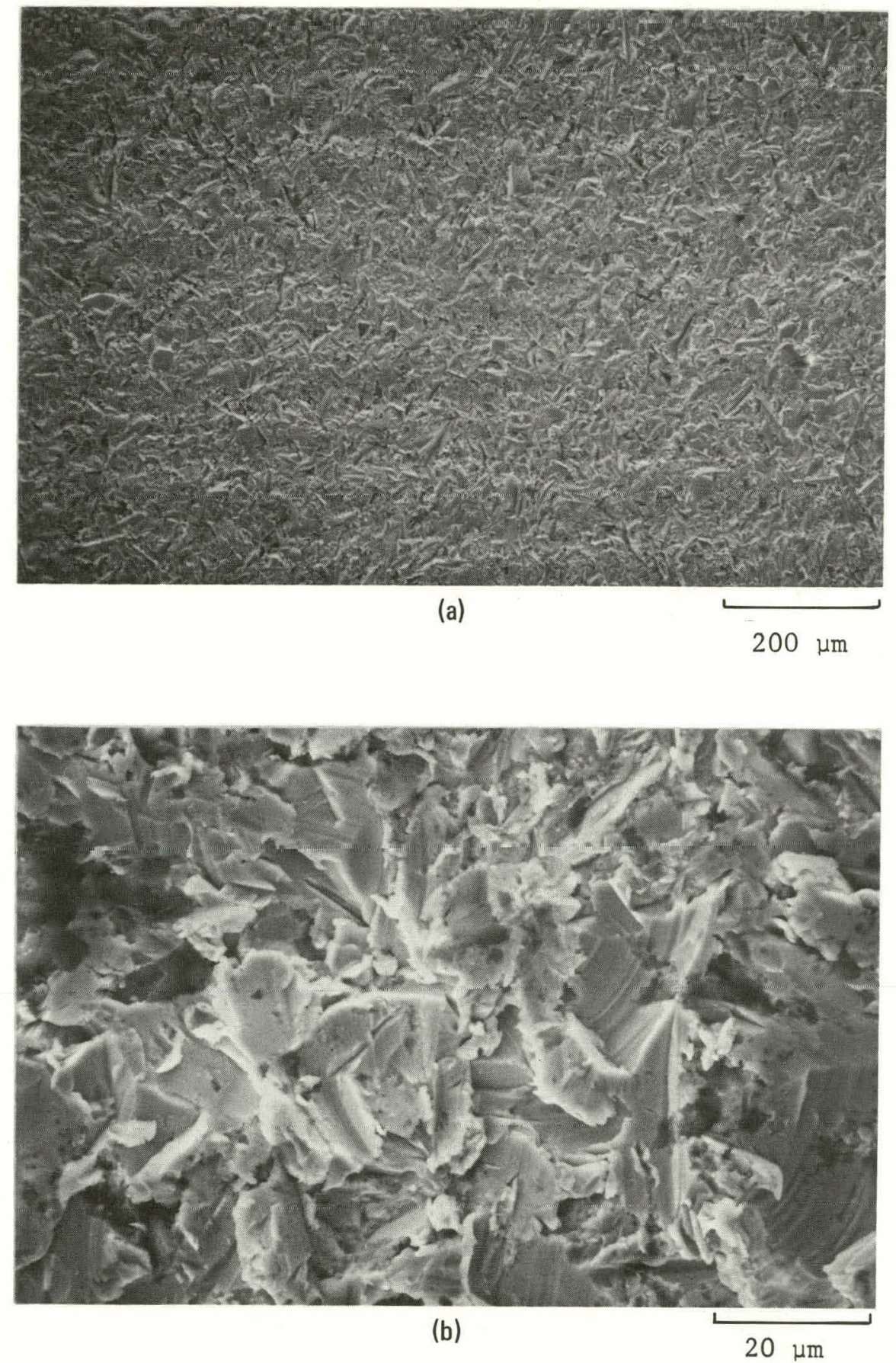

Fig. 12. Scanning electron micrographs showing typical surface following a grit-blasting treatment on (a) $\mathrm{HK} 40$ and (b) IN $713 \mathrm{LC}$ 
obvious from Fig. 12b that this treatment introduces a great deal of plastic deformation in a near-surface zone of the specimens. It would be expected that diffusion coefficients and possibly the activities of reactive chemical constituents, e.g., Cr, might be affected in this nearsurface layer where defect densities were increased.

Preoxidation treatments were also performed at $900^{\circ} \mathrm{C}$ in still air for times of 1,10 , and $100 \mathrm{~h}$. The resultant oxide films were intended to inhibit carburization in the subsequent controlled-impurity helium exposure. It is important to note that oxides formed in air, where the oxygen activity is very high, might not necessarily be the thermodynamically stable form of oxide that would naturally form in the simulated HTGR-GT environment. Any carburization barrier that would be formed in air would gradually (depending on kinetics) change to the stable form corresponding to the actual reactor environment as service exposure continued. Figures 13 through 16 show the preoxidized surfaces representative of the range of test specimens.

Figure $13 \mathrm{a}$ is representative of the oxides formed on the wrought alloys. The growth of the oxide was primarily columnar, growing out from the surface, once impingement of the nuclei occurred. In Fig 13b oxide spallation occurred on an Alloy $800 \mathrm{H}$ specimen, probably because of the interfacial stresses at the oxide-metal interface and stresses resulting from any mismatch in oxide and metal coefficients of thermal expansion that would be established upon cooling of the specimen from the preoxidation temperature.

Figure 14 shows the stages of oxidation in IN 100 with exposure times of 1,10 , and $100 \mathrm{~h}$. Similar results were obtained for IN 713LC.

Figure 15 shows the oxides formed on HK 40 after a 100-h treatment. Three stages of oxide formation are apparent. The first stage involved the formation of a discontinuous silicon-rich oxide phase and was complete after only $1 \mathrm{~h}$ of exposure. As the exposure time increased, a patchy chromium-rich oxide formed, which gradually covered the surface to the extent shown in Fig. 15a. A close examination of Fig. 15b shows a third 


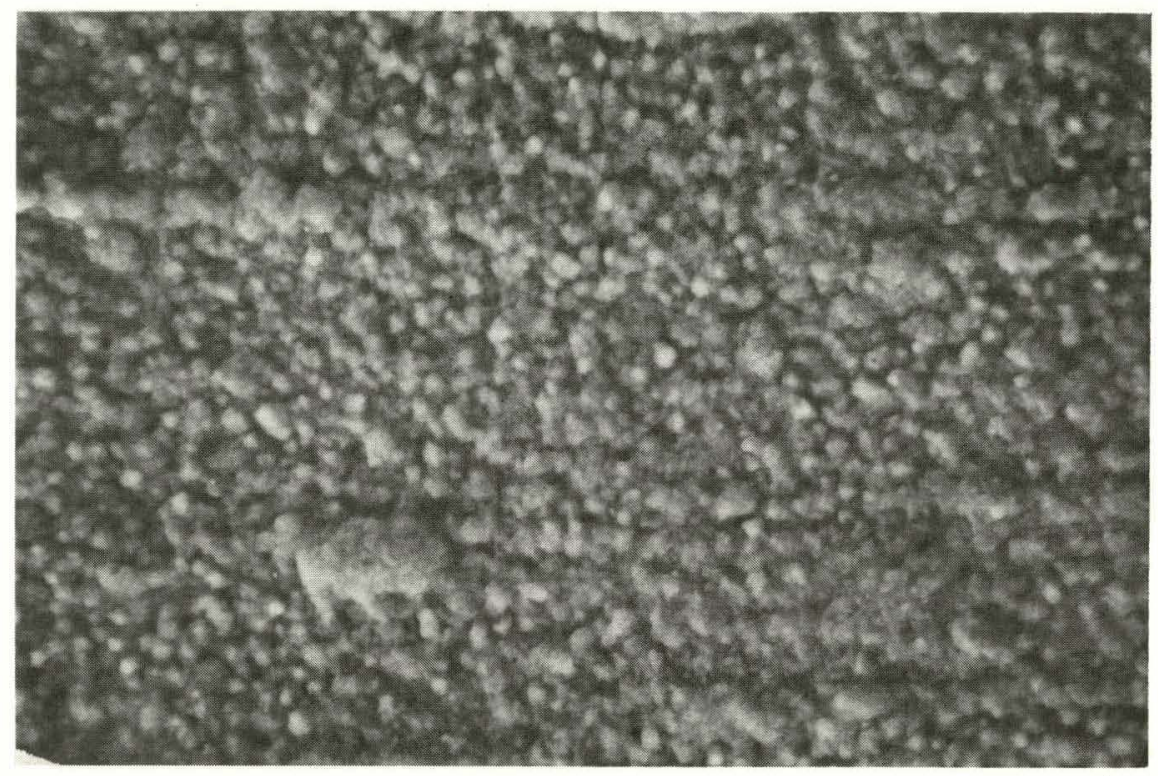

(a)

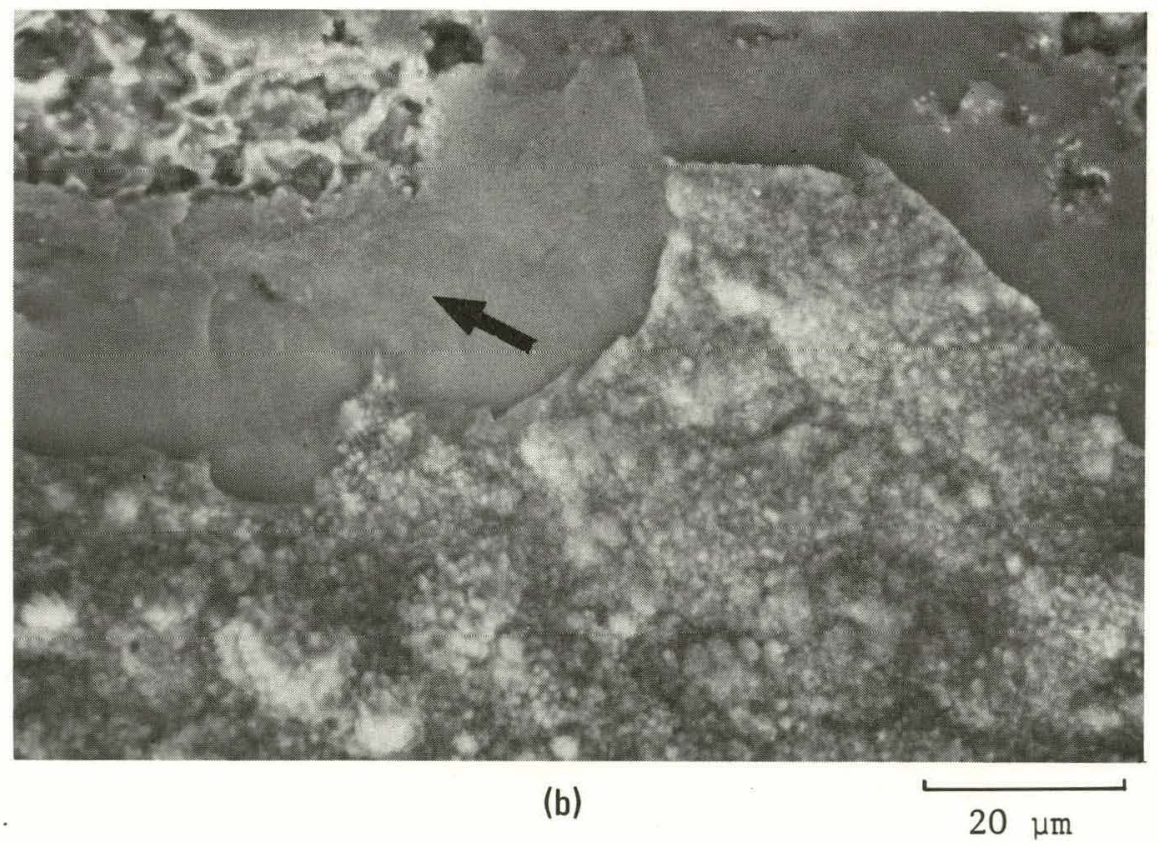

Fig. 13. Scanning electron micrographs showing the surfaces of (a) Inconel 617 and (b) Alloy $800 \mathrm{H}$ following preoxidation treatments at $900^{\circ} \mathrm{C}$ in air for $100 \mathrm{~h}$. Arrow indicates a region where spallation of the oxide film has occurred. 

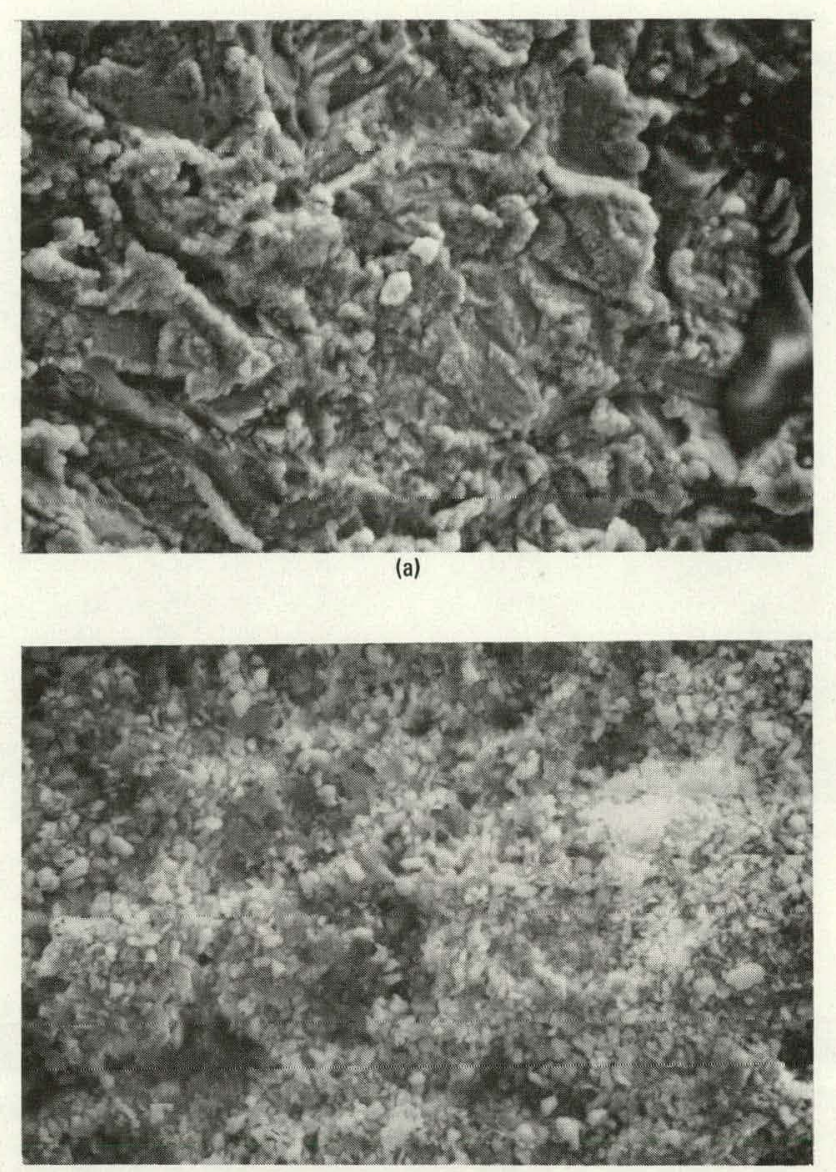

(b)

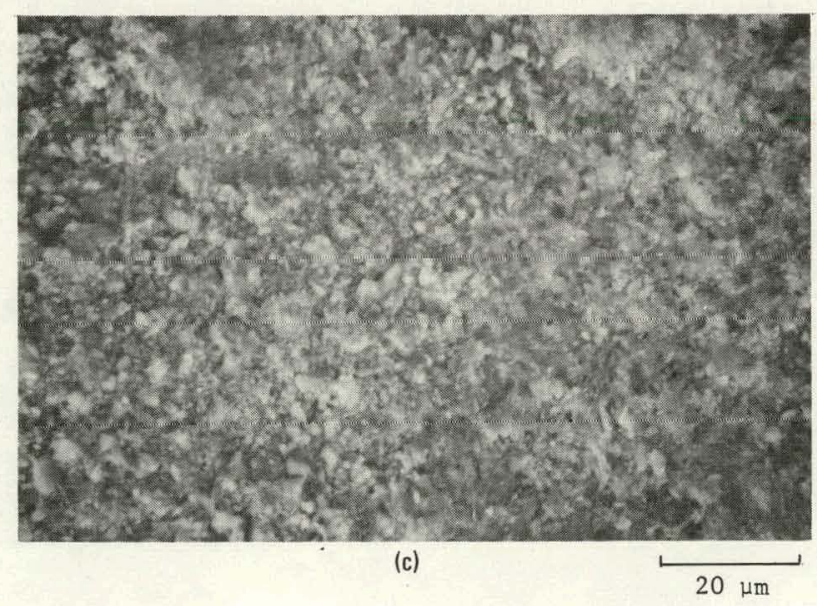

Fig. 14. Scanning electron micrographs showing the surface of IN 100 following preoxidalion treatments in air at $900^{\circ} \mathrm{C}$ for (a) $1 \mathrm{~h}$, (b) $10 \mathrm{~h}$, and (c) $100 \mathrm{~h}$ 


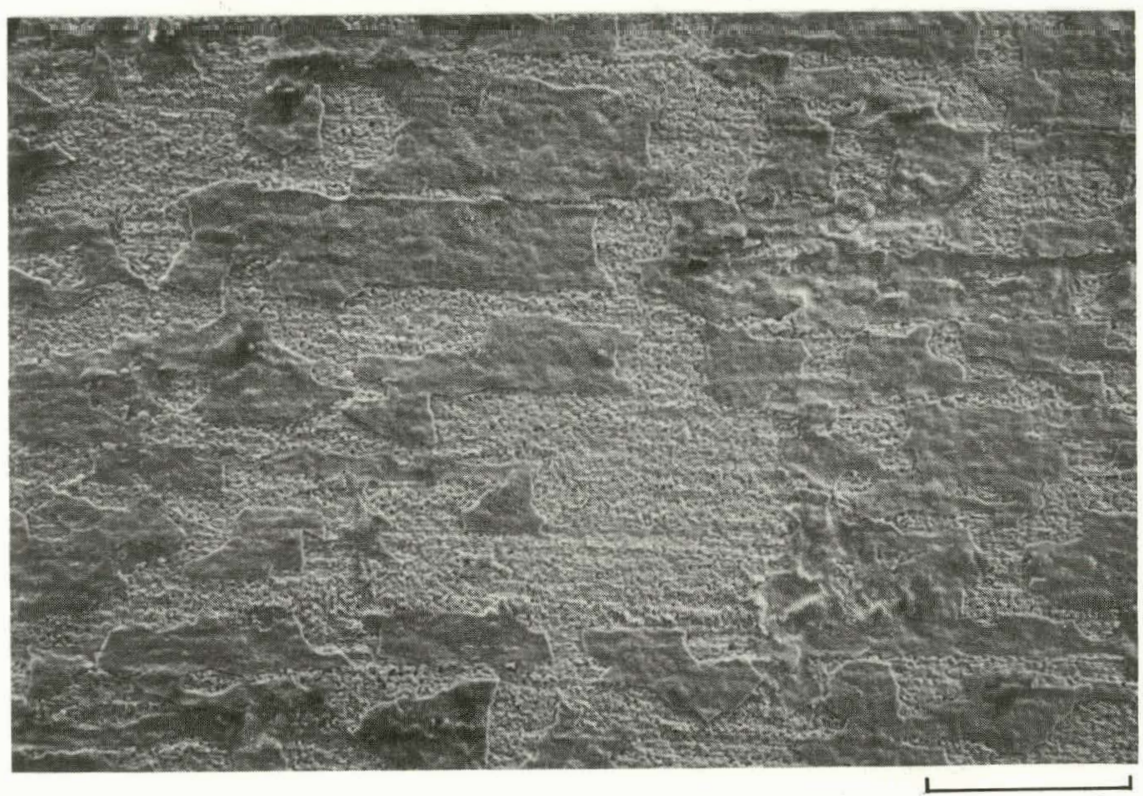

$200 \mu \mathrm{m}$

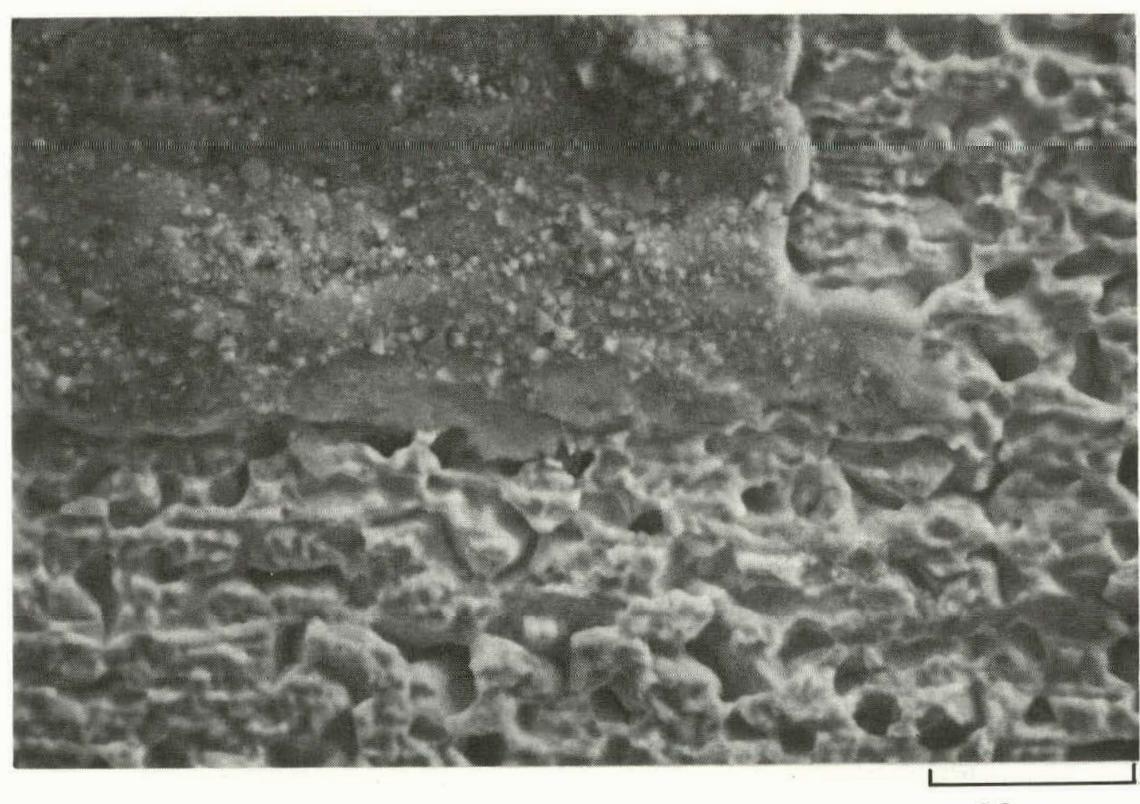

$20 \mu \mathrm{m}$

Fig. 15. Scanning electron micrographs showing the surface condition of $\mathrm{HK} 40$ following a $100-\mathrm{h}$ preoxidation treatment at $900^{\circ} \mathrm{C}$ in air 


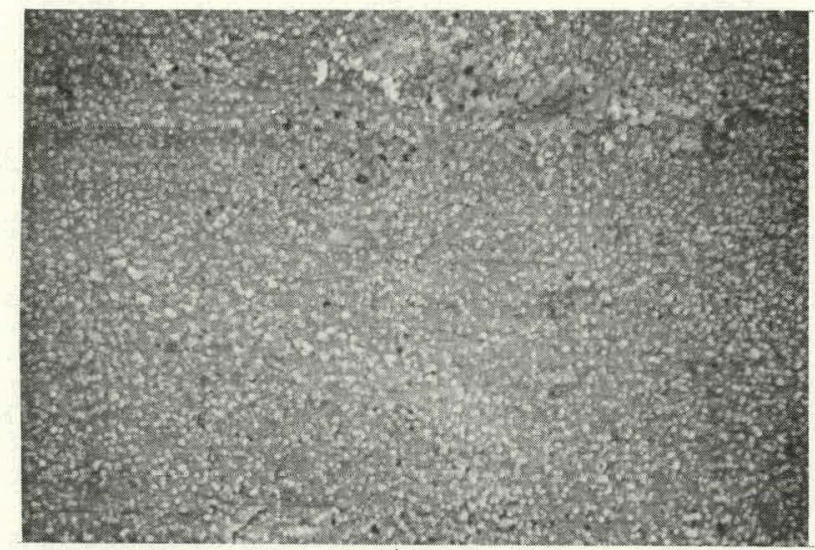

(a)

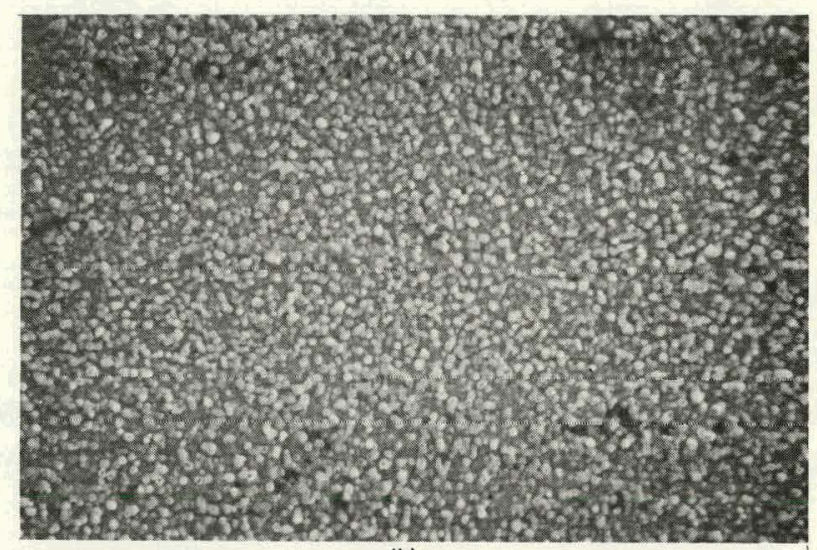

(b)

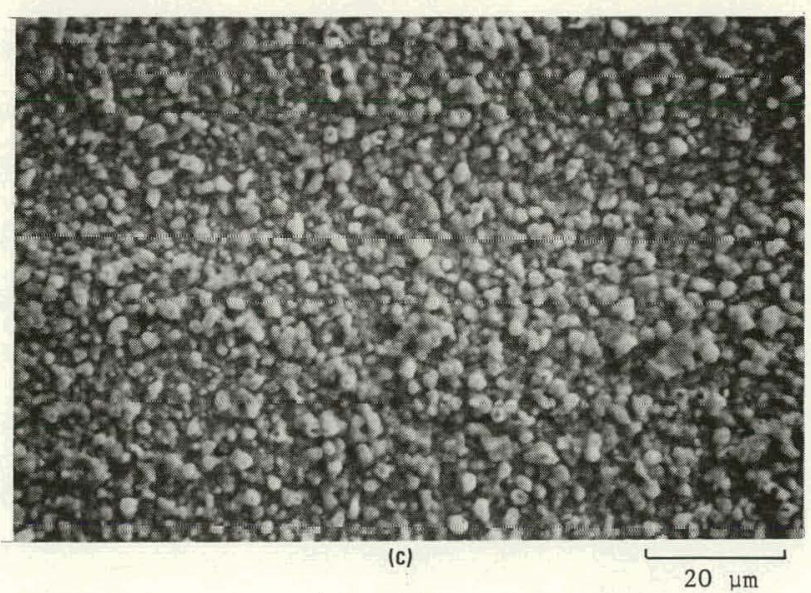

Fig. 16. Scanning electron micrographs showing the surface of MA 754 following preoxidation treatments in air at $900^{\circ} \mathrm{C}$ for (a) $1 \mathrm{~h}$, (b) $10 \mathrm{~h}$, and (c) $100 \mathrm{~h}$ 
phase (presumably an oxide), which nucleated on the patchy chromium-oxide areas. Longer-term exposures would be necessary to bring the oxide formation reactions to a stable or metastable condition.

Figure 16 shows the stages of oxide growth on MA 754 as a function of exposure time. The chromium-rich oxide nucleated preferentially on the yttria particles very near to the surface creating many small oxide nodules. As the exposure time increased these nodules coarsened and eventually coalesced, forming a thin oxide surface layer.

\subsection{CONTROLLED-IMPURITY HELIUM EXPOSURE}

The specimens were exposed isothermally at $900^{\circ} \mathrm{C}\left(1652^{\circ} \mathrm{F}\right)$ for $3000 \mathrm{~h}$ with interruptions at 500, 1000, 2000, and $3000 \mathrm{~h}$ for weight change measurements. Exposures were conducted in a simulated HTGR-GT environment consisting of helium containing constant concentrations of $500 \mu \mathrm{atm} \mathrm{H}_{2} / 50$

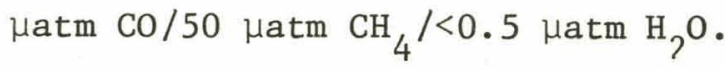

A schematic diagram of the once-through controlled-impurity helium supply system used to generate each desired helium environment is shown in Fig. 17. Bottled high-purity nuclear-grade helium was further purified by passing it through a $5 \AA$ molecular sieve and activated charcoal trap at liquid nitrogen temperature $\left[-196^{\circ} \mathrm{C}\left(-321^{\circ} \mathrm{F}\right)\right]$. Controlled quantities of $\mathrm{H}_{2}$, $\mathrm{CO}$, and $\mathrm{CH}_{4}$ were added by metering research-purity gases into the purified helium stream. Each controlled-impurity helium mixture was then introduced into a high-temperature retort and exhuasted to atmosphere. No intentional addition of $\mathrm{H}_{2} \mathrm{O}$ was made in the present experiments.

An overriding consideration in the design of the test system was the minimization of impurity depletion in the retorts so that gas of known and constant composition would be available to react with all specimens during exposure. Specimens were contained in alumina sample holders and exposed in 70-mm (2.75-in.) i.d. by 910-mm (36-in.) long, single-ended alumina retort $j$, using an alumina gas inlet tube in order to eliminate 


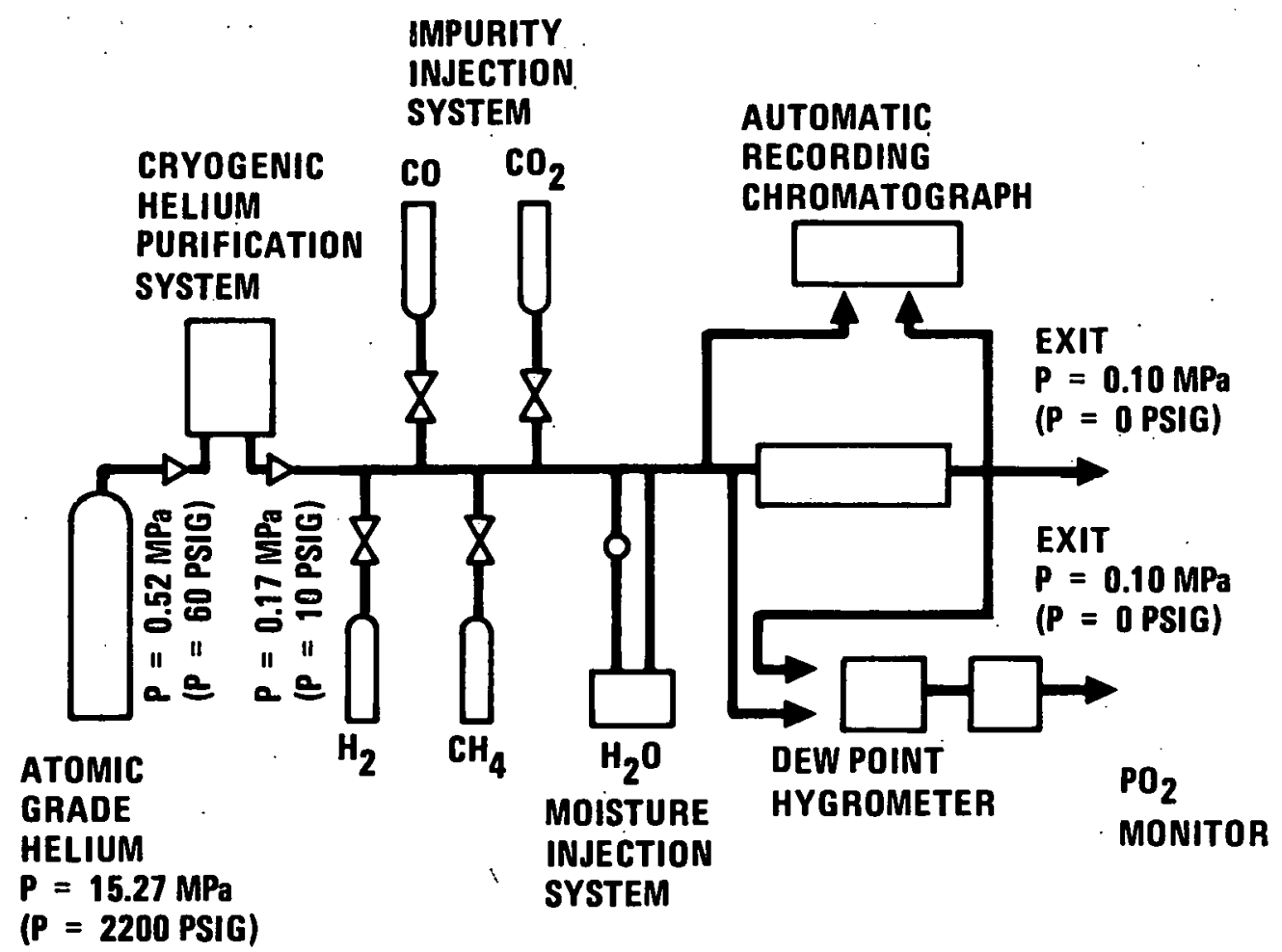

Fig. 17. Schematis diagram of environment cuntrul system for parametric helium impurity corrosion study 
reactive metal surfaces other than the specimens themselves. In addition to these precautions, flow rates through each retort were maintained at $1000 \mathrm{~cm}^{3} / \mathrm{min}$ to further minimize changes in gas composition from inlet to outlet. The impure helium gas mixtures in the retorts were maintained at positive $(1.67 \mathrm{~atm})$ pressure to minimize the possibility of air leaks into the test system. Heating of the retorts was accomplished using three-zone Lindberg horizontal tube furnaces with a 610-mm (24-in.) hot zone. The test zone was $75 \mathrm{~mm}$ ( 3 in.) long and contained three equally spaced monitoring thermocouples along its length. The center thermocouple was used for furnace control. Temperature in the test zone was maintained to within $\pm 5^{\circ} \mathrm{C} \cdot\left( \pm 9^{\circ} \mathrm{F}\right)$.

Test monitoring instrumentation included a Carle Model III $\mathrm{H}$ (S series) automatic gas chromatograph for determination of $\mathrm{H}_{2}, \mathrm{CO}, \mathrm{CO}_{2}$, and $\mathrm{CH}_{4}$ partial pressures; an EG\&G Model 440 extended-range dew point hydrometer for the determination of $\mathrm{H}_{2} \mathrm{O}$ partial pressure; and a modified Thermox zirconia cell oxygen probe for the qualitative determination of $0_{2}$ partial pressure. The helium composition in and out of each retort was measured at least once weekly, and $\mathrm{H}_{2}, \mathrm{CO}$, and $\mathrm{CH}_{4}$ levels were maintained to within $\pm 10 \%$ of nominal.

\subsection{TEST PROCEDURE}

Exposure of the specimens was interrupted at 500, 1000, 2000, and $3000 \mathrm{~h}$ for visual examination and weight change measurements. Specimens were removed after 3000- $h$ exposures for destructive analyses. All corrosion specimens removed from testing were cut perpendicular to their longitudinal axis to obtain sections for metallography, bulk carbon analysis, and surface studies.

Metallography of etched and unetched sections was performed to study surface corrosion scales, internal oxidation, carburization, and thermal aging effects. Mean oxidation and carburization depths were both measured by taking the average of eight metallographic measurements around the specimen cross section. 
Alloy phases and the compositions of surface scales were identified by scanning electron microscope (SEM) microprobe analysis, including selected area energy-dispersive X-ray (EDX) analysis and X-ray analysis. 


\section{EXPERIMENTAL RESULTS}

Interactions occurred between the impurity species in the controlledimpurity helium and the alloys to varying degrees for all test alloys and exposure times. These interactions were manifested by the formation of both surface and internal oxides and carbides, the formation of nearsurface denuded zones where alloying element depletion was observed, and near-surface intergranular and intragranular carbide precipitation (carburization). To the extent that these reactions occurred, the test specimens exhibited variations in surface discoloration, scale formation, changes in weight, and changes in carbon concentration.

\subsection{WEIGHT CHANGE}

Weight change measurements, taken perodically throughout the controlled-impurity helium exposure, serve as a means to monitor the corrosion behavior of the test specimens. In all cases the weight changes were normalized with respect to the individual specimen surface areas. Figures 18 through 24 show the weight change data as a function of exposure time for the present tests.

With the exception of MA 754, all alluys displayed positive weight changes, which tended to increase with increasing exposure time. Occasiona11y an abrupt weight loss was observed, particularly in the case of preoxidized specimens. These weight losses are associated with spallation of the oxide scales upon thermal cycling of the specimens when tests were interrupted to obtain data. Generally speaking, parabolic corrosion rates were observed for those alloys that displayed positive weight changes. In all cases, positive weight changes resulted from either oxidation or a combination of oxidation and carburization. 


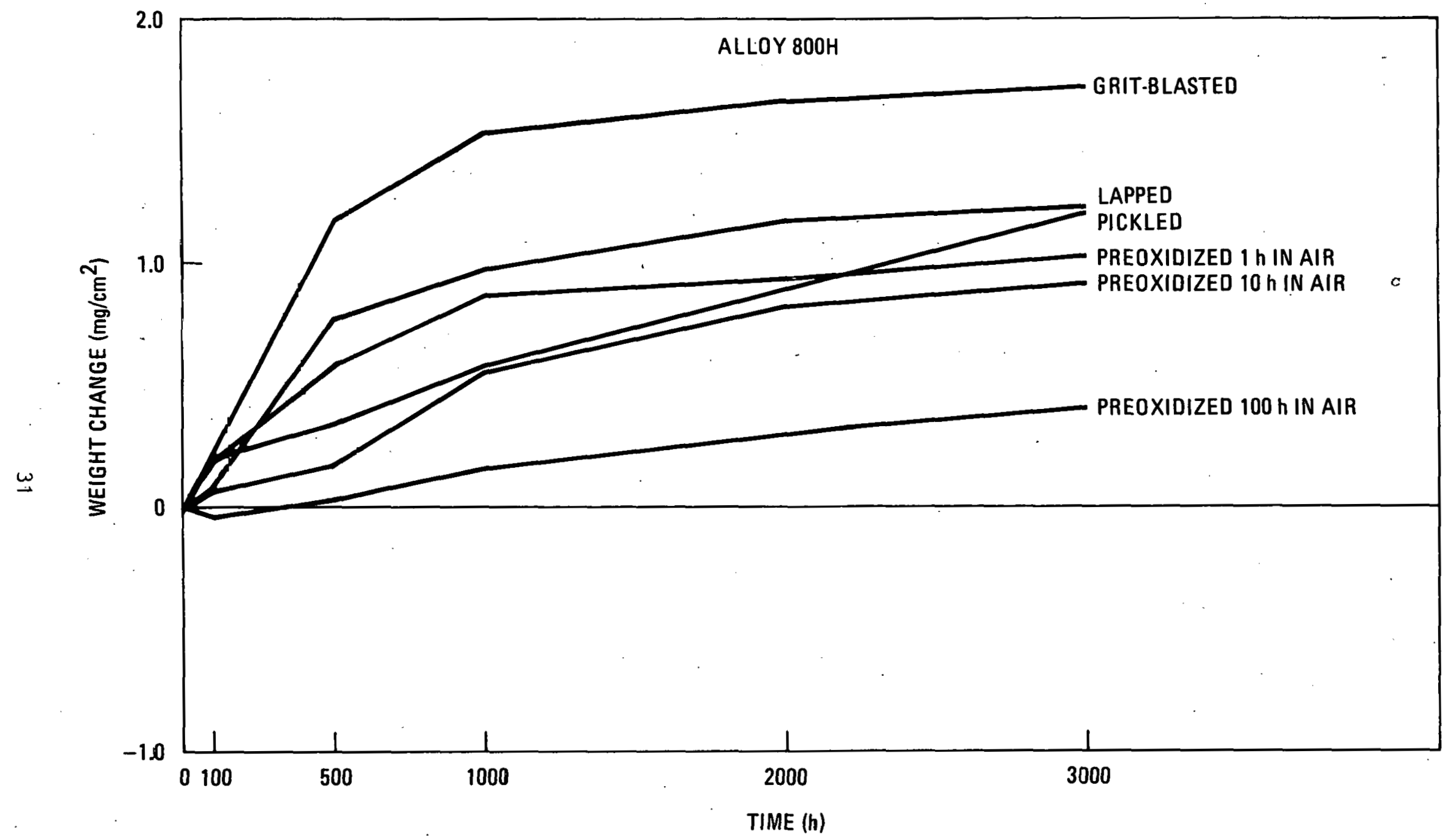

Fig. 18. Weight change as a function of exposure time for Alloy $800 \mathrm{H}$ exposed at $900^{\circ} \mathrm{C}$. in

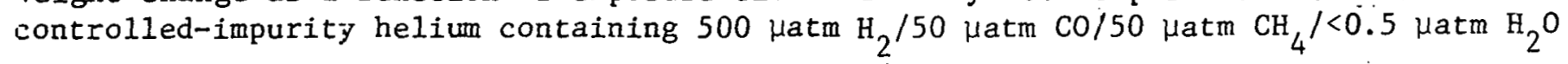




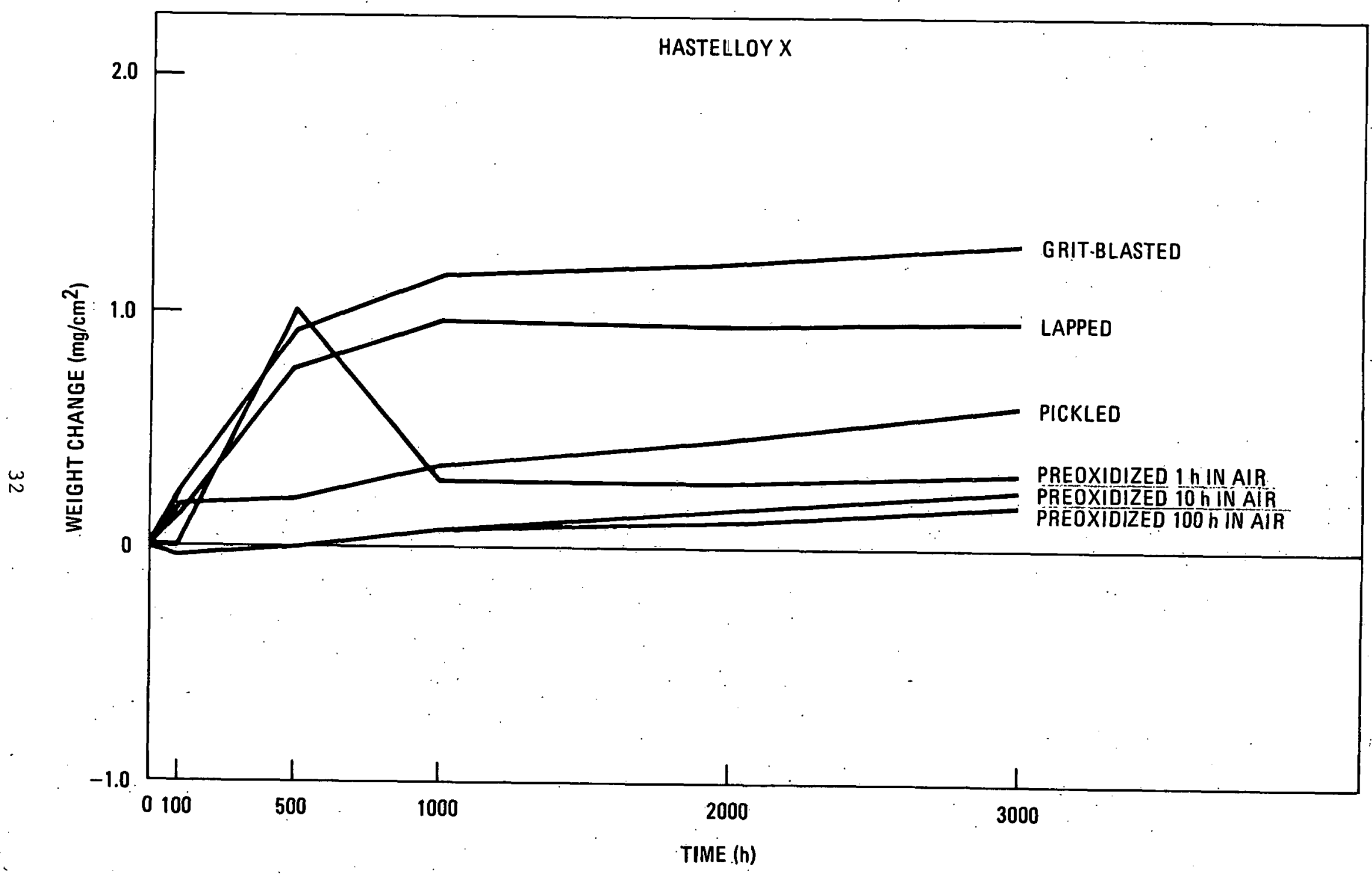

Fig. 19. Weight change as a function of exposure time for Hastelloy $\mathrm{X}$ exposed at $900^{\circ} \mathrm{C}$ in controlled-

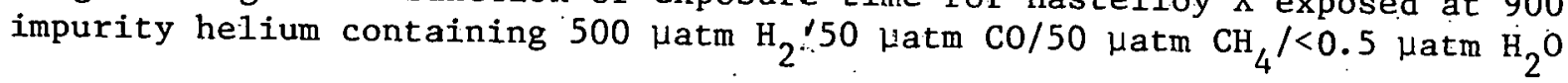




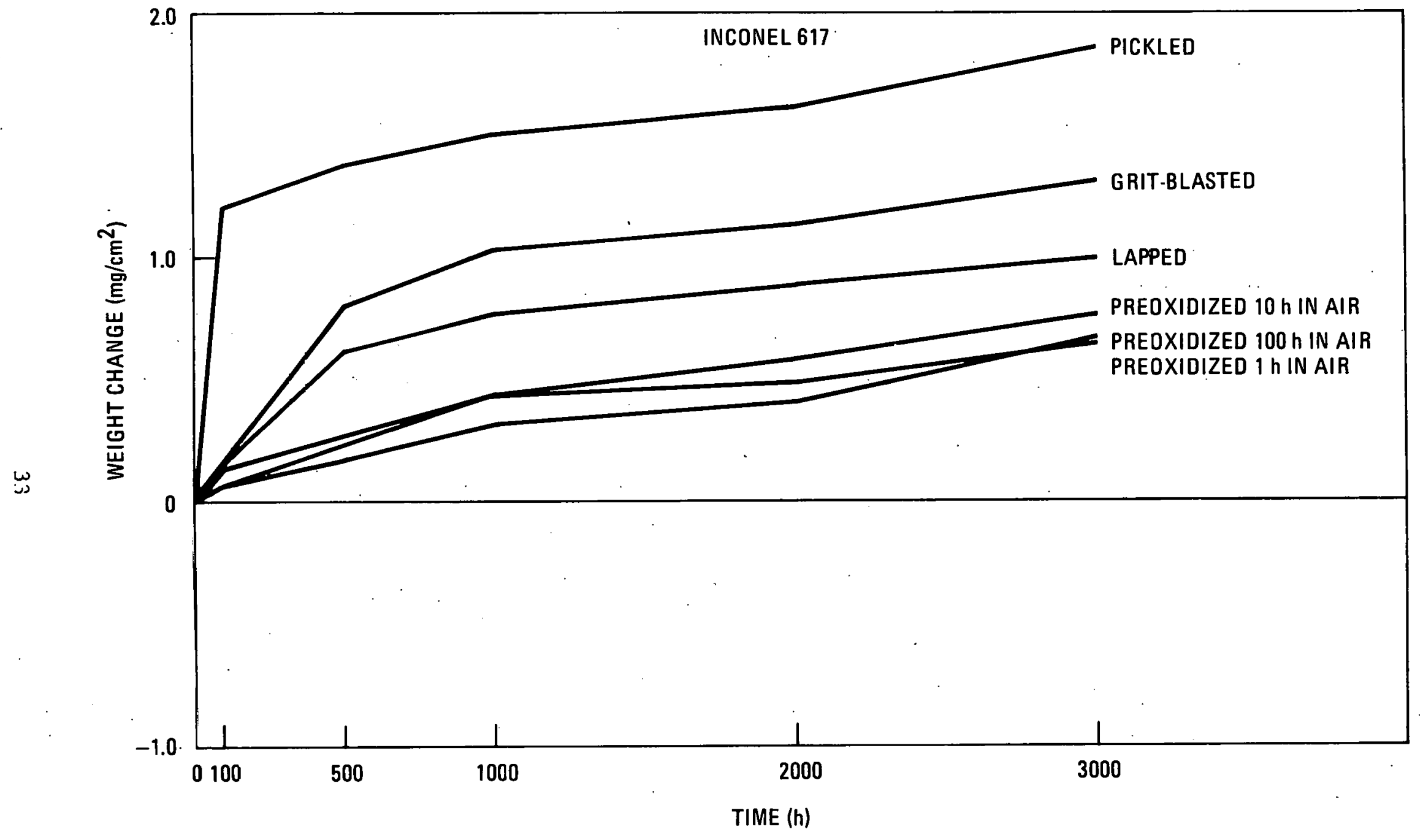

Fig. 20. Weight change as a function of exposure time for Inçonel 617 exposed at $900^{\circ} \mathrm{C}$ in controlled-impurity helium containing $500 \mu \mathrm{atm} \mathrm{H}_{2} / 50 \mu \mathrm{atm} \mathrm{CO} / 50 \mu \mathrm{atm} \mathrm{CH}_{4} /<0.5 \mu \mathrm{atm} \mathrm{H}_{2} \mathrm{O}$ 


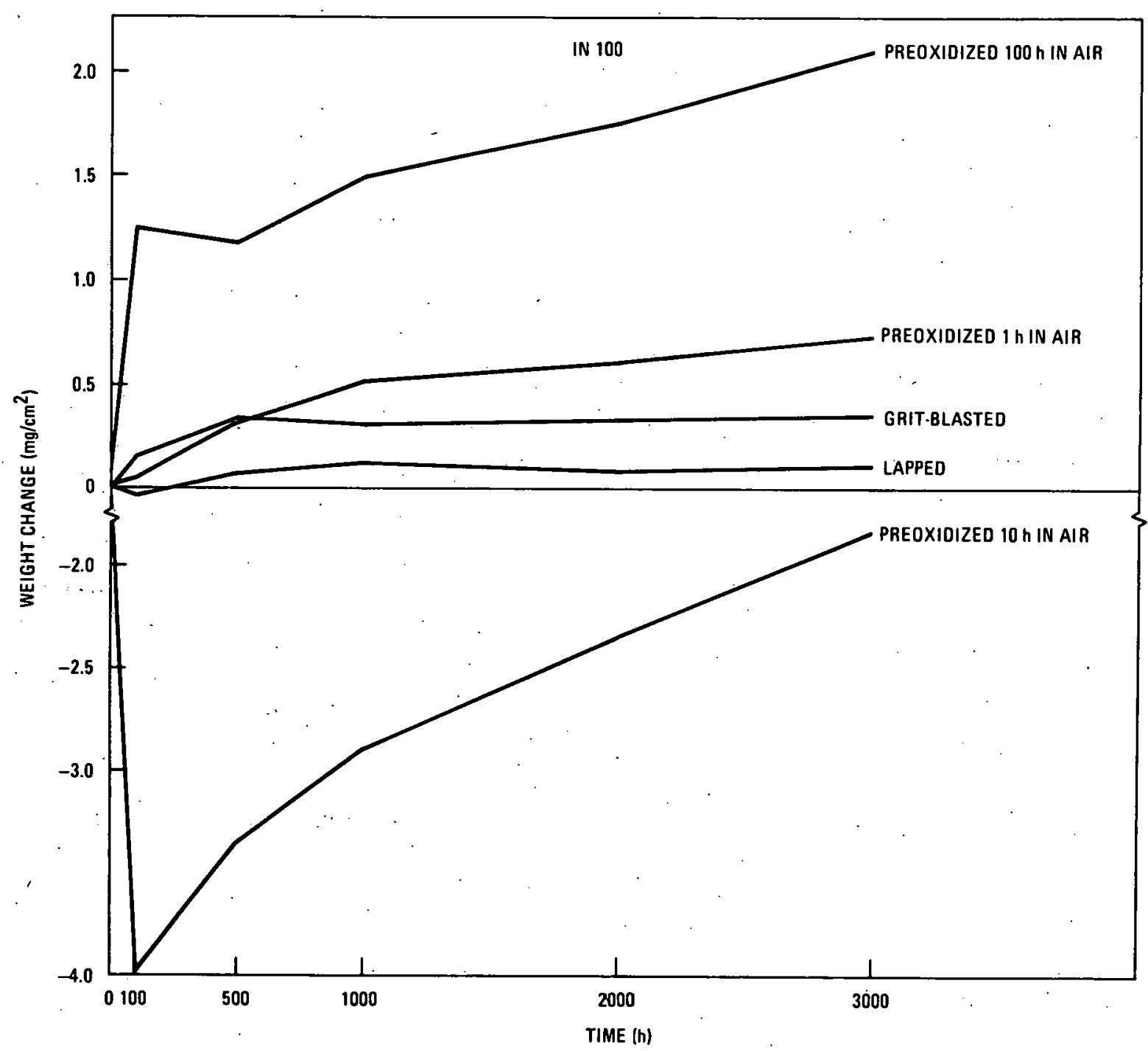

Fig. 21. Weight change as a function of exposure time for. IN 100 exposed at $900^{\circ} \mathrm{C}$ in controlled-

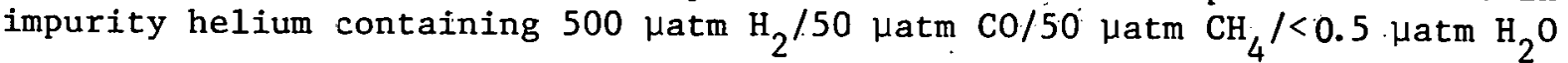




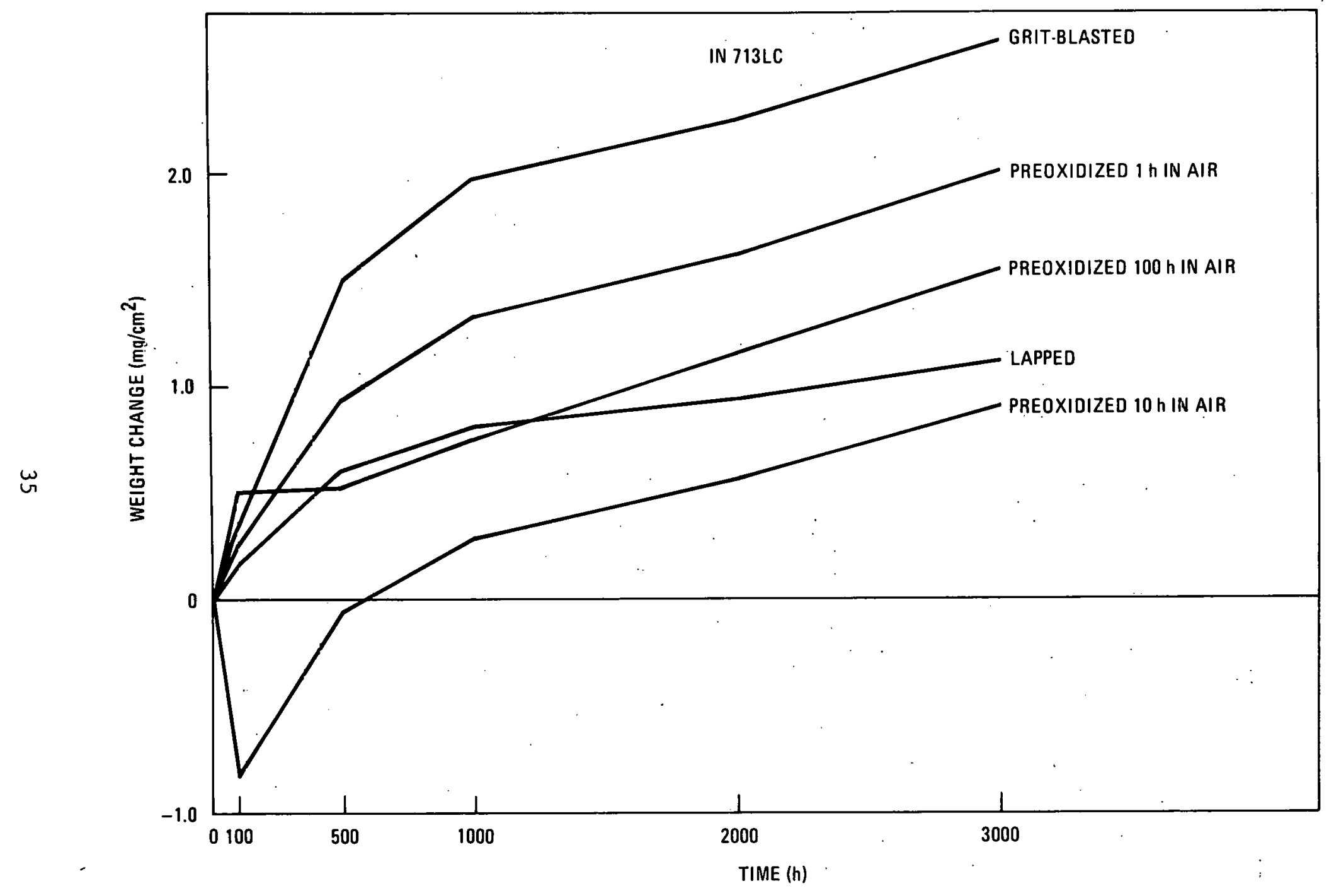

Fig. 22. Weight shange as a function of exposure time for IN $713 \mathrm{LC}$ exposed at $900^{\circ} \mathrm{C}$ in controlled-

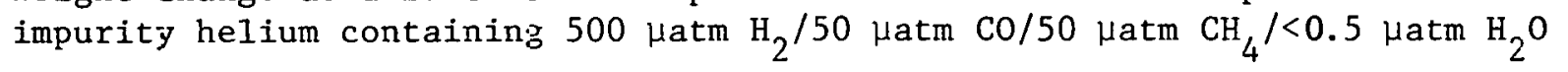




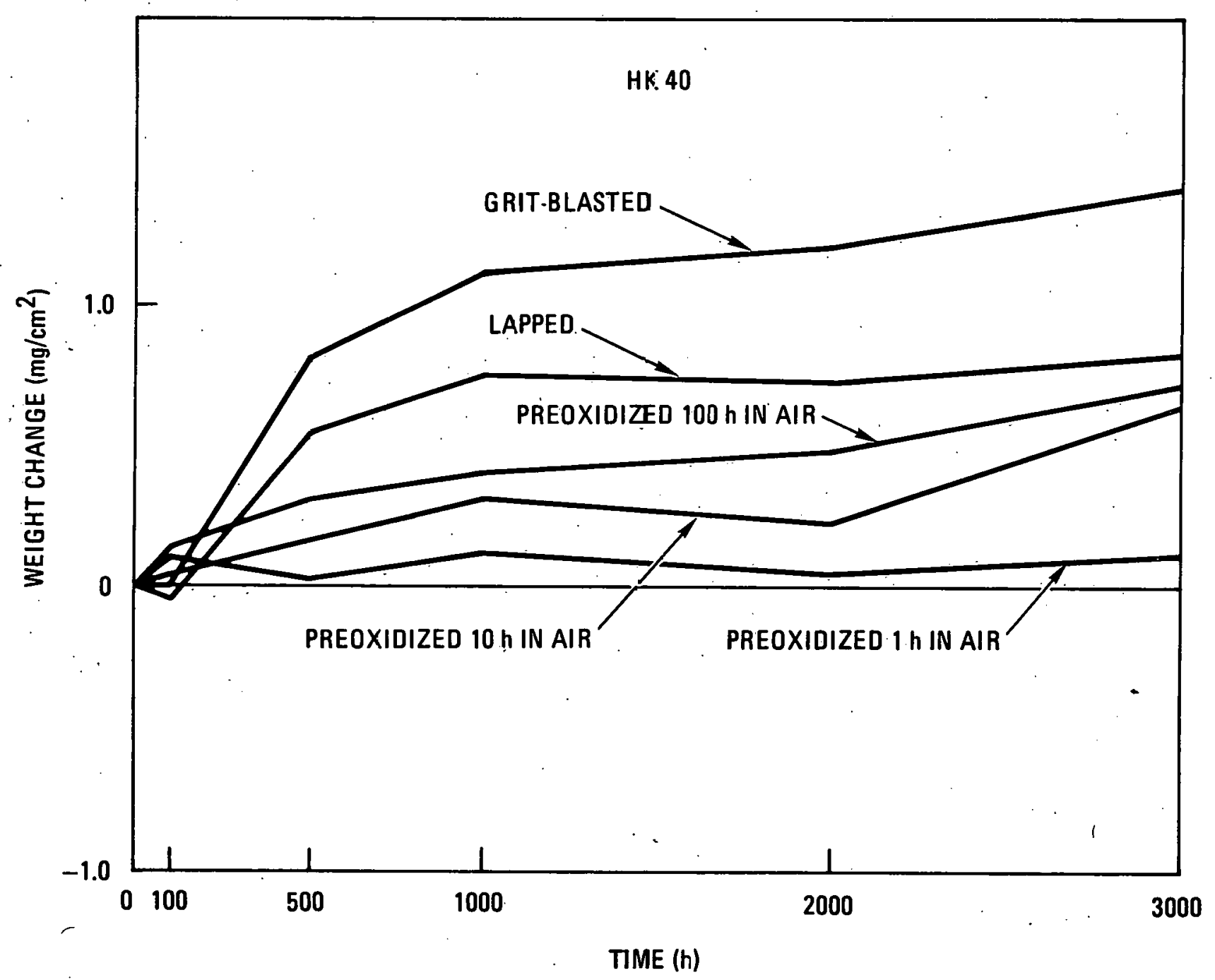

Fig. 23. Weight change as a function of exposure time for HK 40 exposed at $900^{\circ} \mathrm{C}$ in controlledimpurity helium containing $500 \mu \mathrm{atm} \mathrm{H}_{2} / 50 \mu \mathrm{atm} \mathrm{CO} / 50 \mu \mathrm{atm} \mathrm{CH}_{4} /<0.5 \mu \mathrm{atm} \mathrm{H}_{2} \mathrm{O}$ 


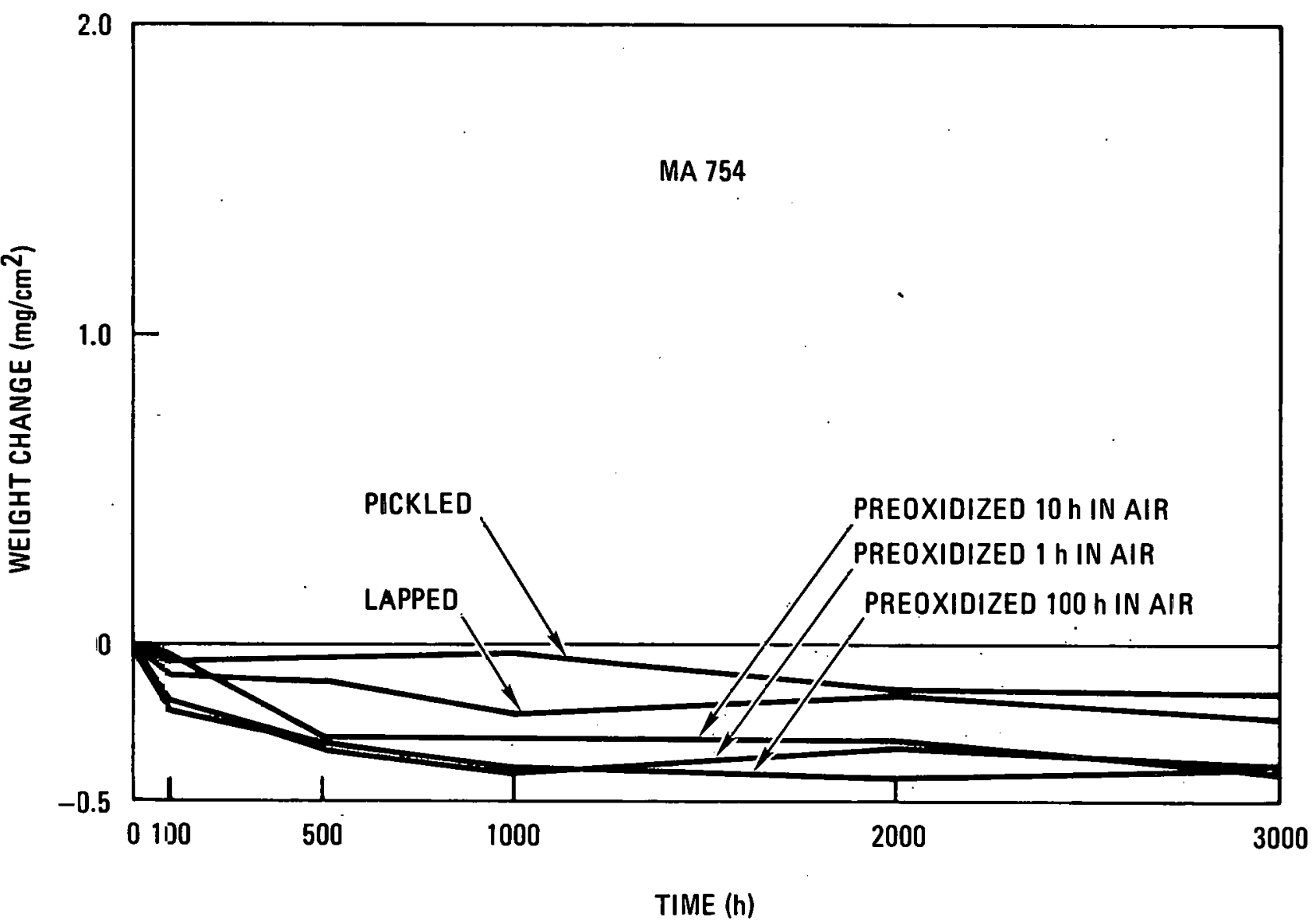

Fig. 24. Weight change as a function of exposure time for MA 754 exposed at $900^{\circ} \mathrm{C}$ in controlled-impurity helium containing $500 \mu \mathrm{atm} \mathrm{H}_{2} / 50 \mu \mathrm{atm} \mathrm{CO} / 50 \mathrm{\mu atm} \mathrm{CH}_{4} /<0.5 \mu \mathrm{atm} \mathrm{H}_{2} \mathrm{O}$ 
In Figs. 18 through 21 it is interesting to note that for the wrought high-temperature alloys the magnitude of the weight gain with increasing exposure time was consistently lowest for those specimens that were given the preoxidation treatments prior to the controlled-impurity helium exposures. This was not the case, however, for the remainder of the alloys tested. Also important is the fact that for the wrought alloys, the weight gains leveled off almost completely after the 3000-h exposure, which is an indication that the interactions had decreased and the scales formed had limited the kinetics of further gas-metal interactions.

MA 754 exhibited negative weight changes as a function of exposure time independent of surface condition (Fig. 24). This particular alloy has been observed to decarburize in previous experiments in controlledimpurity helium exposures (Ref. 5). It can be assumed that the carbon loss overshadowed any weight increase associated with the formation of an oxide film.

\subsection{PREOXIDATION SCALE FORMATION}

The preoxidized surface scales were shown in Figs. 13 through 16. Cross sections of the preoxidized specimens were prepared metallographically and the preoxidized scales were studied to more fully characterize the effects of the preoxidation treatments.

Figures 25 through 31 show the oxide scales formed on the test alloys upon preoxidation at $900^{\circ} \mathrm{C}$ in air. From Figs. 25 and 26, the oxides formed on Alloy $800 \mathrm{H}$ and Hastelloy $\mathrm{X}$ tended to be thin, continuous, and tenacious. Evidence of substantial internal oxidation can be noted for the longer preoxidation times, particularly for Alloy $800 \mathrm{H}$. In Alloy $800 \mathrm{H}$, alumina scales formed along grain boundaries and extended inward from the outer scales. By X-ray analysis, the outer surface scales were determined to be essentially $\mathrm{Cr}_{2} \mathrm{O}_{3}$. Below these scales the oxidation potential decreases dramatically as the distance from the exposed surface increases. Generally, below the surface scale the oxygen activity has decreased to a point where chromium can no longer oxidize. Other more 


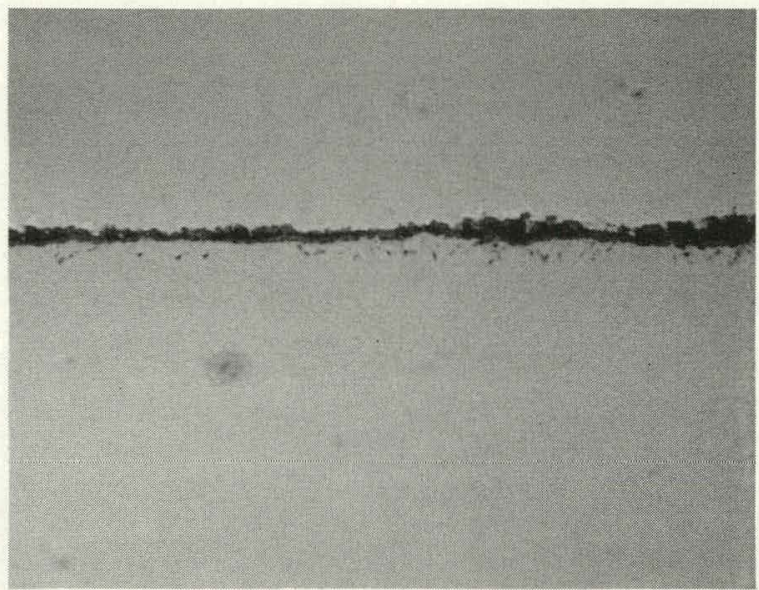

(a)

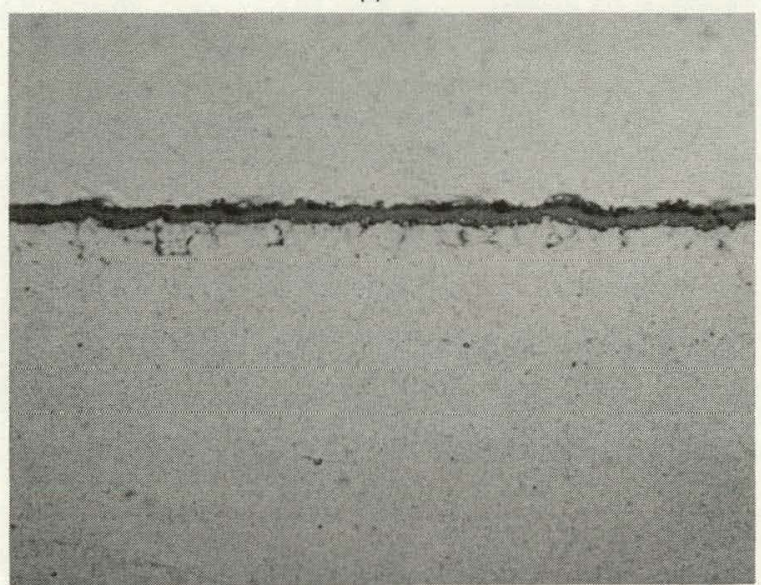

(b)

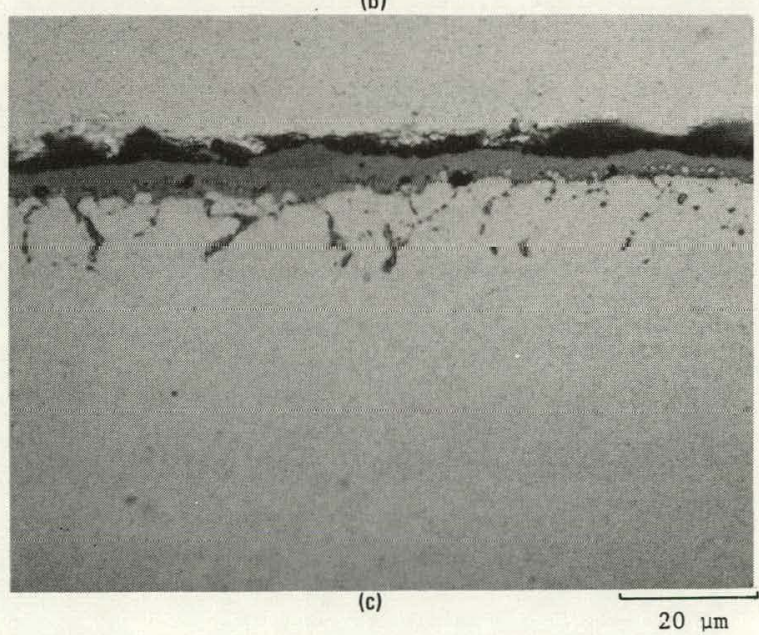

Fig. 25. Surface oxide scales formed on Alloy $800 \mathrm{H}$ specimens during preoxidation treatments at $900{ }^{\circ} \mathrm{C}$ in air for (a) $1 \mathrm{~h}$, (b) $10 \mathrm{~h}$, and (c) $100 \mathrm{~h}$ 

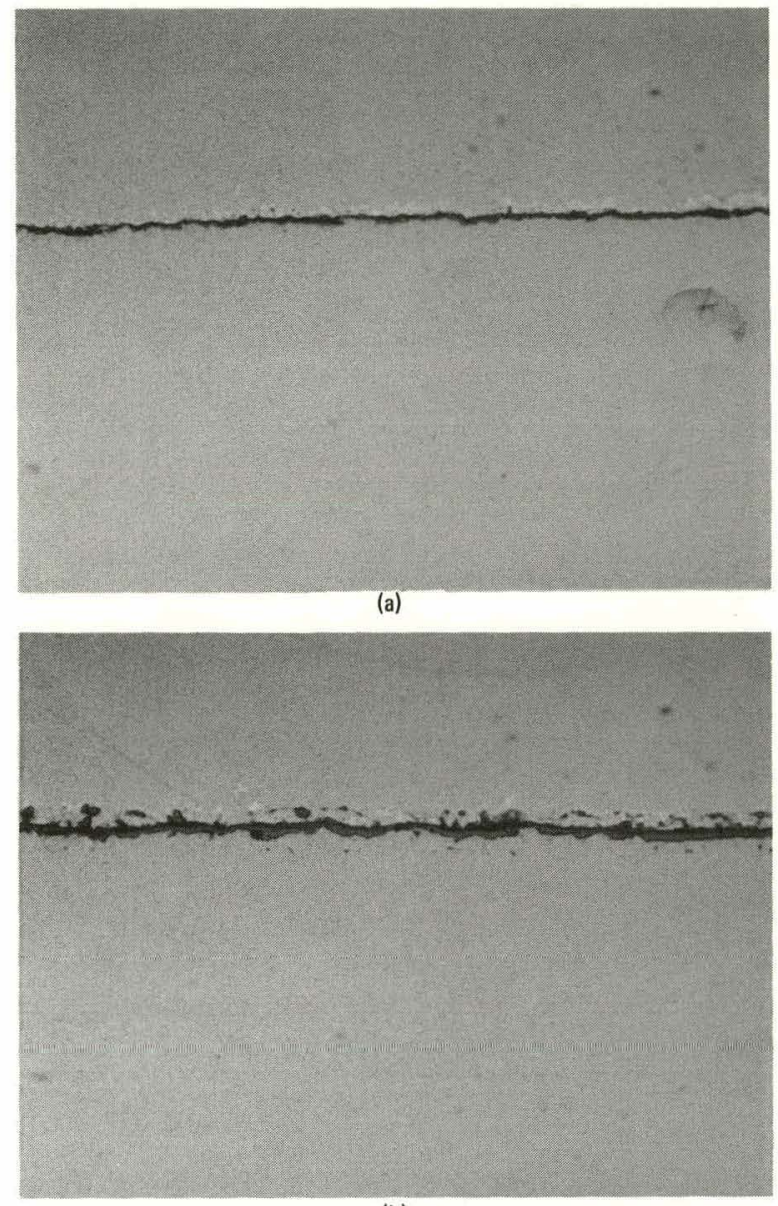

(b)

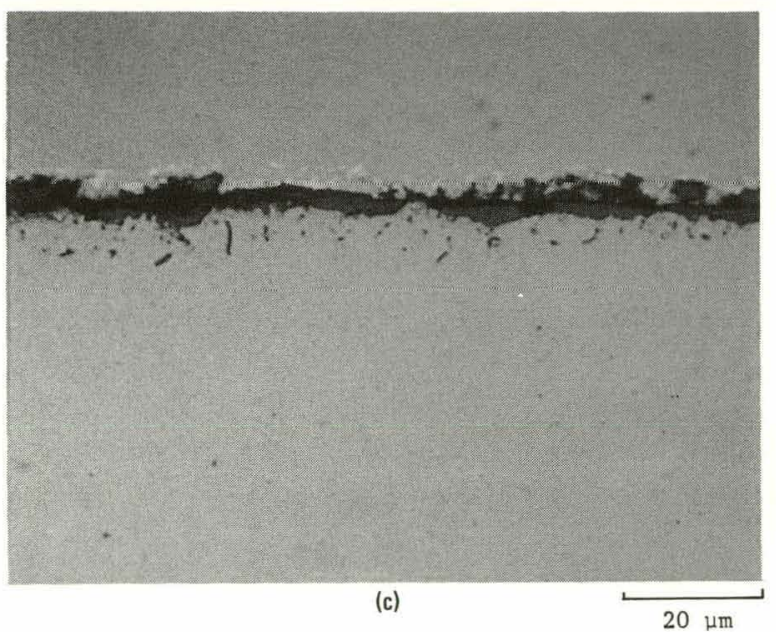

Fig. 26. Surface oxide scales formed on Hastelloy $\mathrm{X}$ specimens during preoxidation treatments at $900^{\circ} \mathrm{C}$ in air for (a) $1 \mathrm{~h}$, (b) $10 \mathrm{~h}$, and $100 \mathrm{~h}$ 


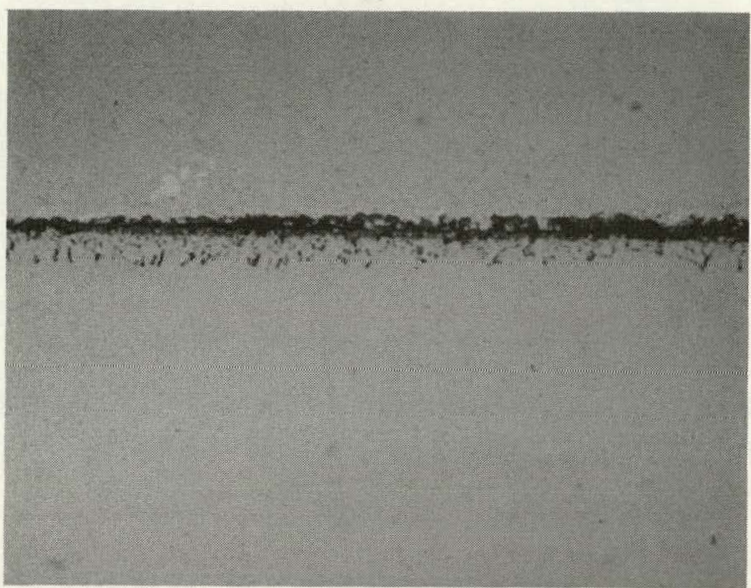

(b)

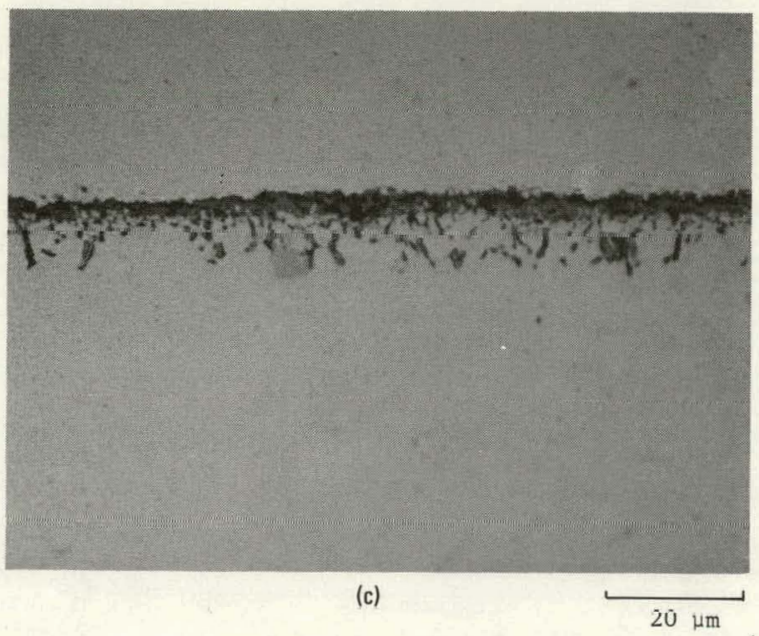

Fig. 27. Surface oxide scales formed on Inconel 617 specimens during preoxidation treatments at $900^{\circ} \mathrm{C}$ in air for (a) $1 \mathrm{~h}$, (b) $10 \mathrm{~h}$, and (c) $100 \mathrm{~h}$ 


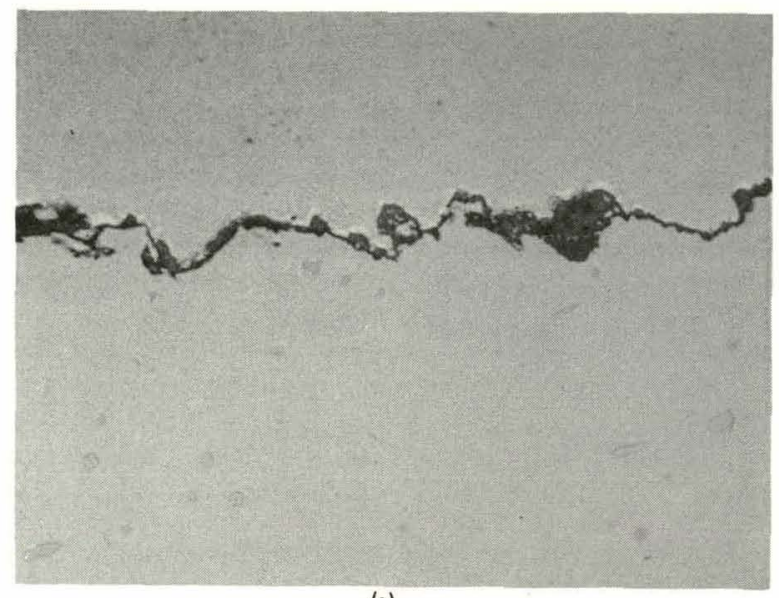

(a)

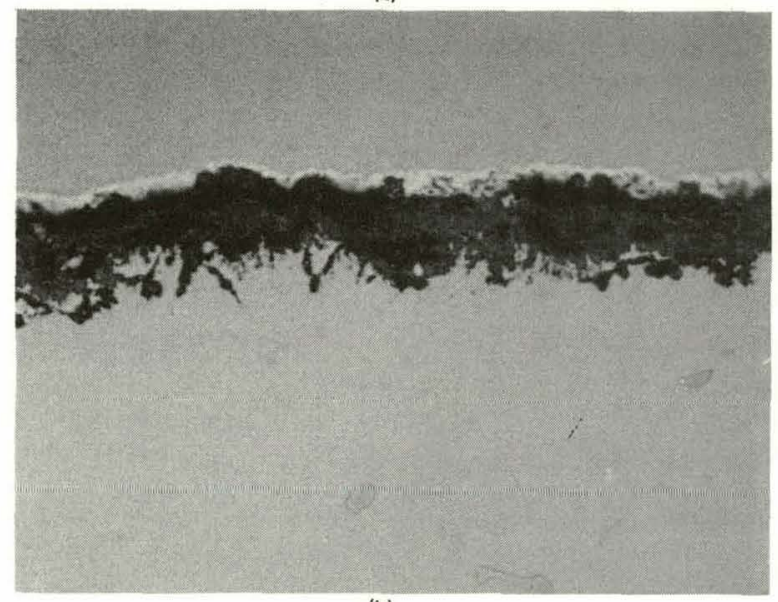

(b)

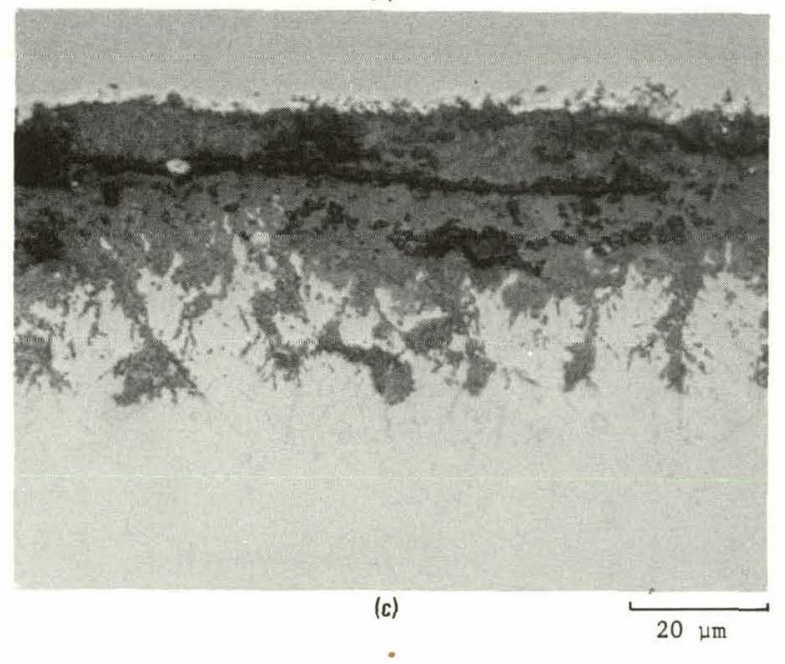

Fig. 28. Surface oxide scales formed on IN 100 specimens during preoxidation treatments at $900^{\circ} \mathrm{C}$ in air for (a) $1 \mathrm{~h}$, (b) $10 \mathrm{~h}$, and (c) $100 \mathrm{~h}$ 


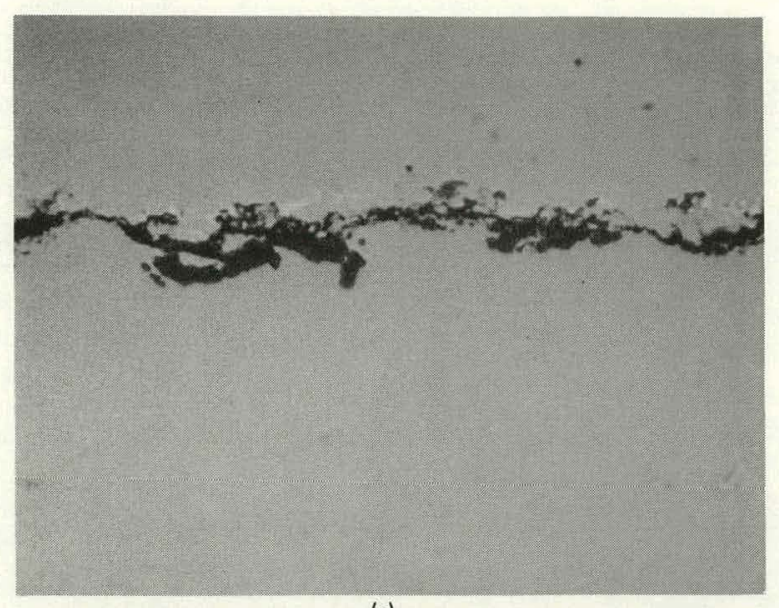

(a)

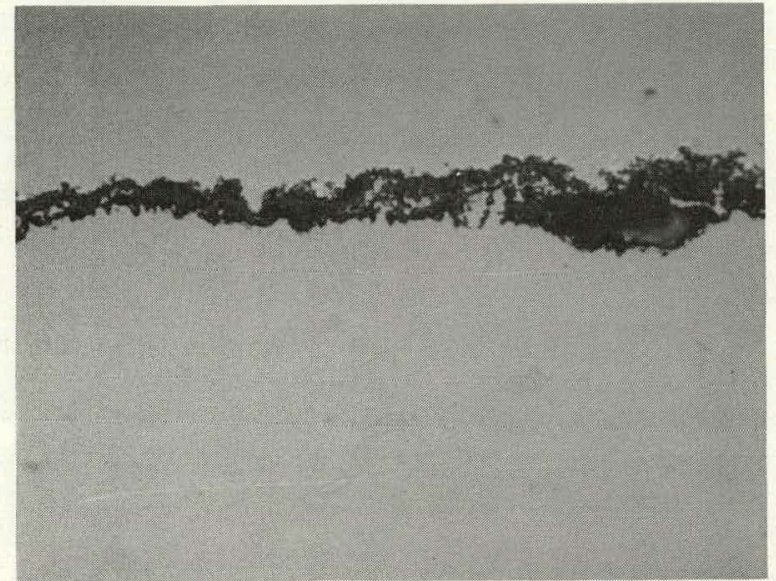

(b)

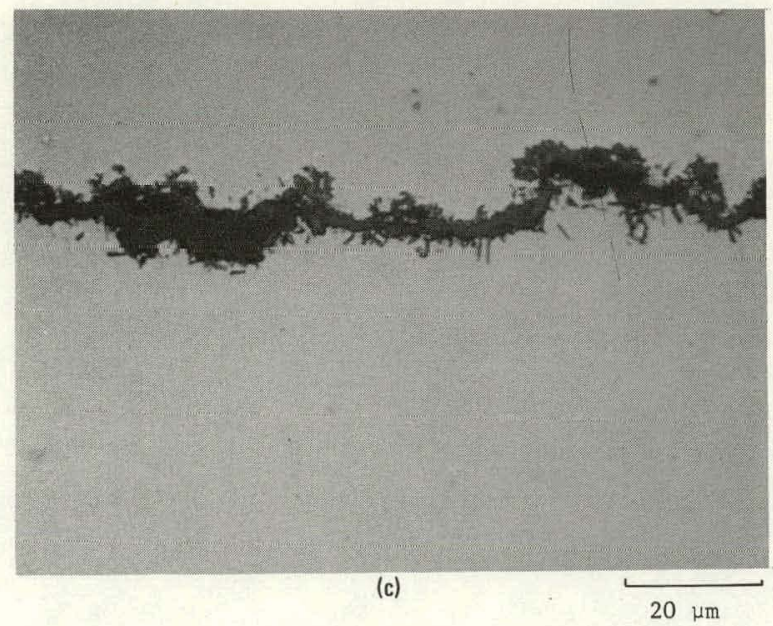

Fig. 29. Surface oxide scales formed on IN 713LC specimens during preoxidation treatments at $900^{\circ} \mathrm{C}$ in air for (a) $1 \mathrm{~h}$, (b) $10 \mathrm{~h}$, and (c) $100 \mathrm{~h}$ 

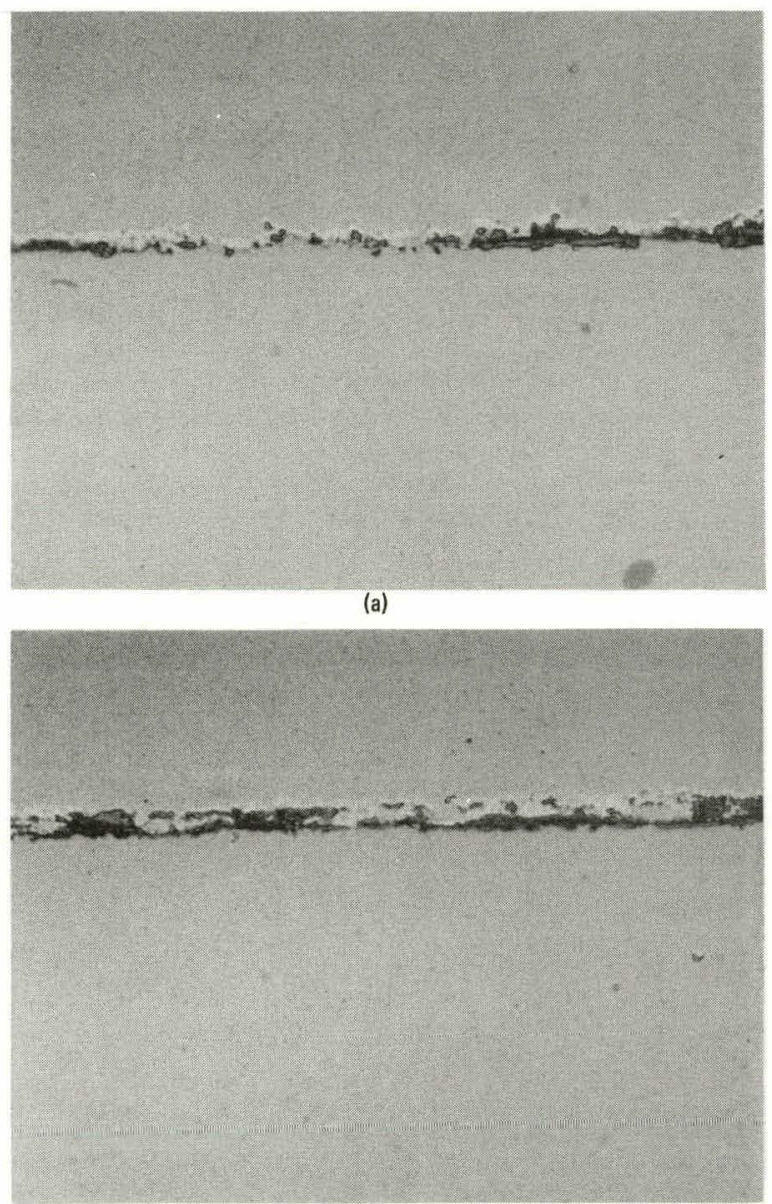

(b)

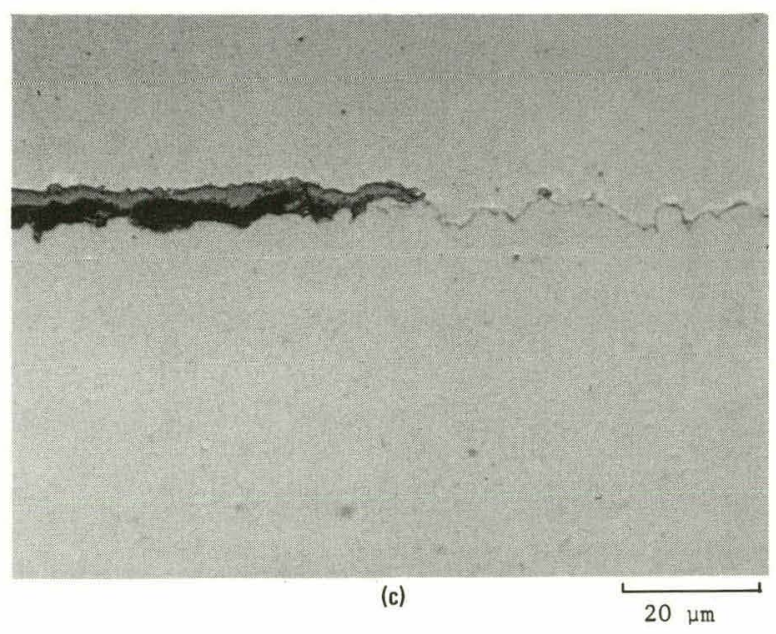

Fig. 30. Surface oxide scales formed on HK 40 specimens during preoxidation treatments at $900^{\circ} \mathrm{C}$ in air for (a) $1 \mathrm{~h}$, (b) $10 \mathrm{~h}$, and (c) $100 \mathrm{~h}$ 

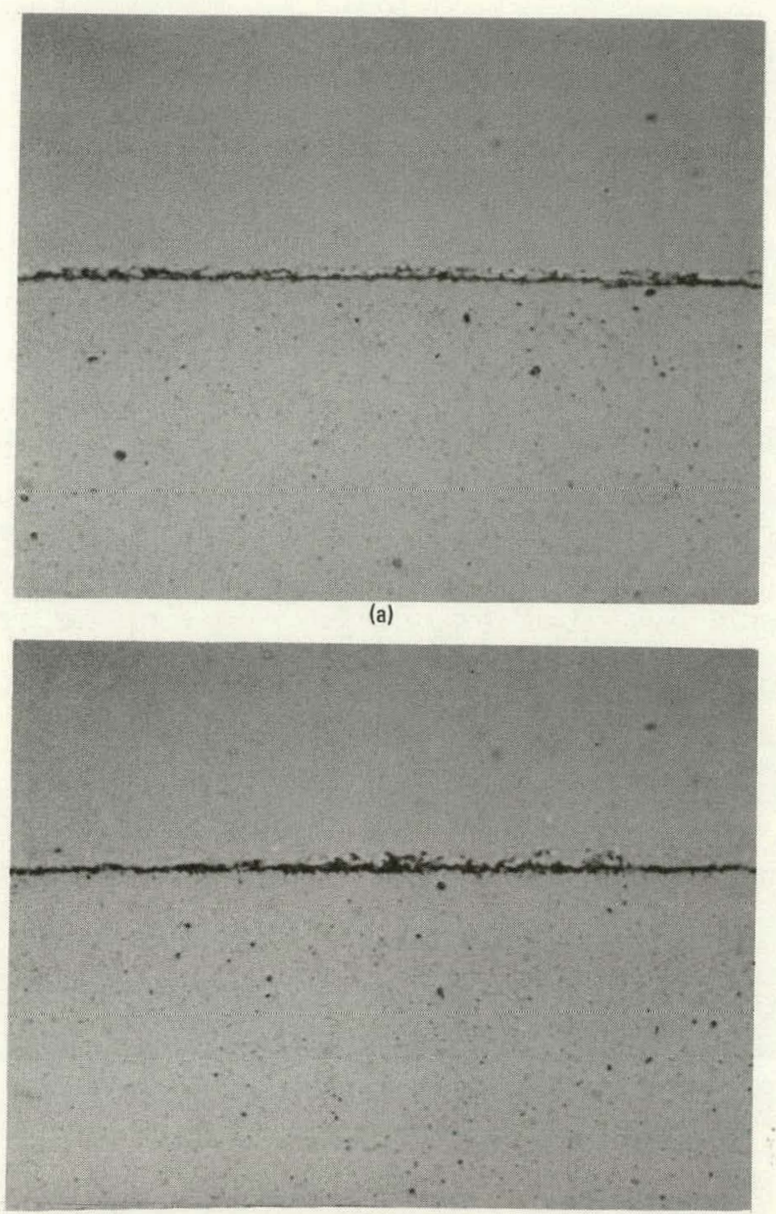

(b)

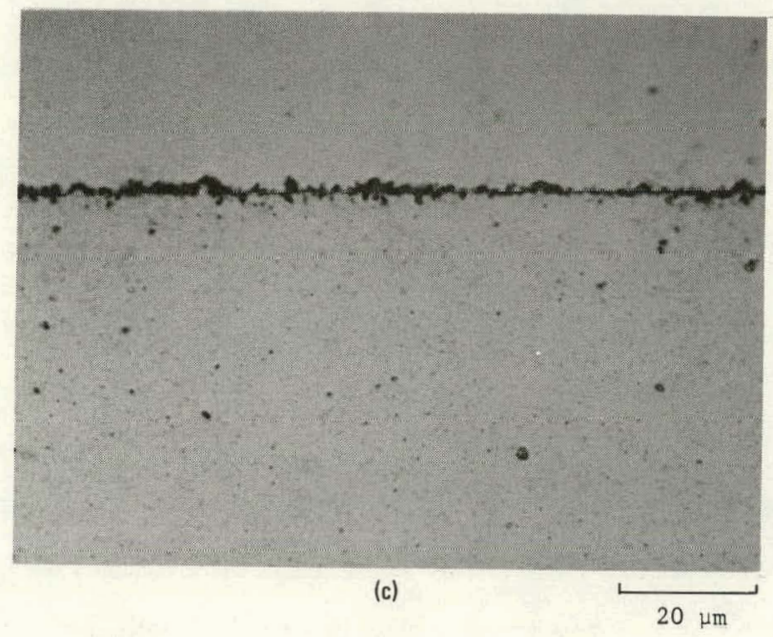

Fig. 31. Surface oxide scales formed on MA 754 specimens during preoxidation treatments at $900^{\circ} \mathrm{C}$ in air for (a) $1 \mathrm{~h}$, (b) $10 \mathrm{~h}$, and (c) $100 \mathrm{~h}$ 
reactive chemical constituents, such as silicon or aluminum, can still form oxides under the conditions of low-oxidation potential, and intruding grainboundary internal oxides resulted.

For the other wrought alloy, Inconel 617, the chromium-rich surface oxide was less continuous, as shown in Fig. 27. Although little evidence of scale spallation was observed (see also Fig. 20), the lack of continuity of the scale would limit its effectiveness as a barrier to carburization in subsequent HTGR-GT environmental exposures. Again, internal oxidation was observed, which increased in severity as the preoxidation time increased.

Figures 28 and 29 show the stages of oxide formation as a function of preoxidation time at $900^{\circ} \mathrm{C}$ for IN 100 and IN 713LC, the two cast supera11oys. Both alloys formed discontinuous oxides during an exposure time of $1 \mathrm{~h}$ (FIgs. 28a and 29a), and the scale characteristics were similar for hoth alloys. With longer exposure times, scale formation characteristics became markedly different. Scale evolution in IN 100 became complex, and thick deeply penetrating internal oxides formed (Figs. 28b and 28c). For the case of IN 713LC, more continuous oxide scales formed with the extent of oxidation, i.e., oxidation rate, apparently leveling off between exposure times of 10 and $100 \mathrm{~h}$. There was no indication that the oxidation rate of IN 100 decreased substantially with increasing exposure time.

As mentioned before, the oxidation of HK 40 proceeded through several stages, which are apparent in Fig. 30. The scales formed were discontinuous and the nature of the oxidation behavior seemed to be strongly linked with the orientation of the surface grains. No internal oxidation was observed. Spallation of the surface oxides occurred readily and, in general, the adherence of the oxides appeared to be poor. Spallation of oxide scales formed on HK 40 during controlled-impurity helium exposures has been noted in previous work (Refs. 1-5); however, the utility of this alloy is associated with its ability to resist carburization in severe environmental 
exposures (Ref. 16). The scales formed during preoxidation treatments would seemingly have 1ittle effect in promoting carburization resistance unless the adherence qualities could be improved.

Finally, from Fig. 31, the oxide scale formed on MA 754 during preoxidation was very thin and contained oxide nodules corresponding to areas of preferential oxidation at yttria particle/alloy matrix interfaces. Similar physical characteristics have been noted in previous oxidation studies (Ref. 18), as well as studies involving corrosion in simulated gas-cooled reactor environments (Ref. 5).

\subsection{OXIDATION AND SCALE FORMATION}

It was not the purpose of these experiments to perform detailed studies of the reaction products. The interactions of the environment studied in these experiments ( $\mathrm{He} / 500 \mu \mathrm{atm} \mathrm{H}_{2} / 50 \mu \mathrm{atm} \mathrm{CO} / 50 \mu \mathrm{atm} \mathrm{CH}_{4} /<0.5$ patm $\mathrm{H}_{2} \mathrm{O}$ ) and of similar simulated advanced HTGR environments with the alloys have been extensively studied and reported in past publications (Refs. 1-5). Nonetheless, it was important to compare the surface scales. internal oxidation, and carburization of the specimens to discern any pronounced effects of surface condition. More detailed scale analyses are given in Refs. 1-5.

Figures 32 through 34 show the surface scales that formed on the wrought high-temperature alloys during the controlled-impurity helium exposure. Morphologically the scales are quite similar, independent of surface treatment. Preoxidation treatments resulted in a greater degree of internal oxidation, as might be expected. The surface scales were generally mixed oxides and carbides, although the preoxidized specimens of Alloy $800 \mathrm{H}$ and Hastelloy X appeared to contain few carbides but more matrix material within the surface oxide(s). The scale evolution for these alloys is similar to that observed in previous studies (Refs. 4,5). 


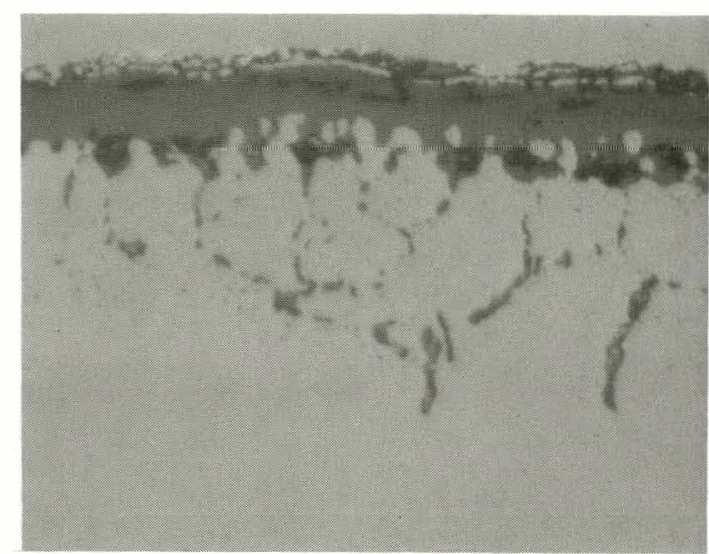

(a)

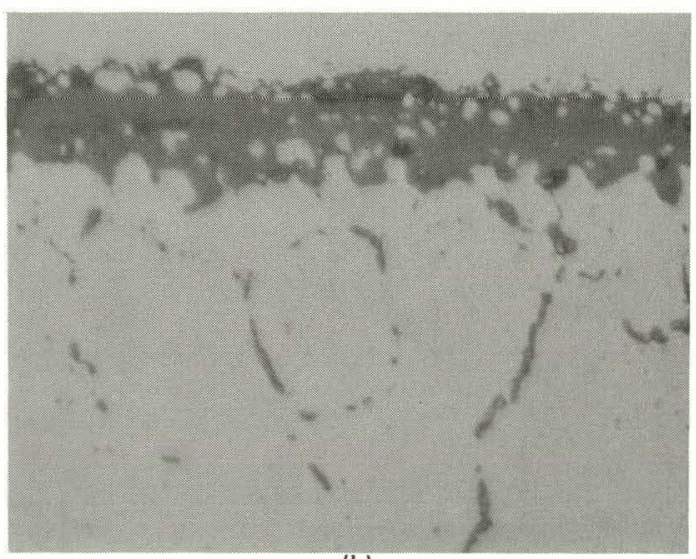

(b)

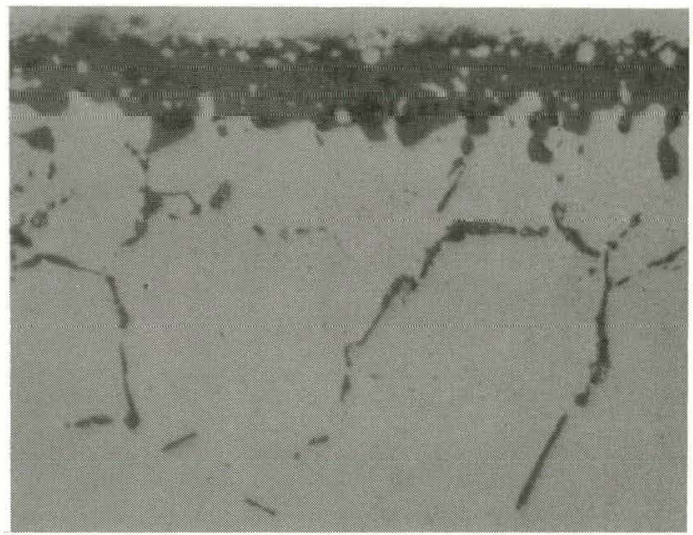

(c)

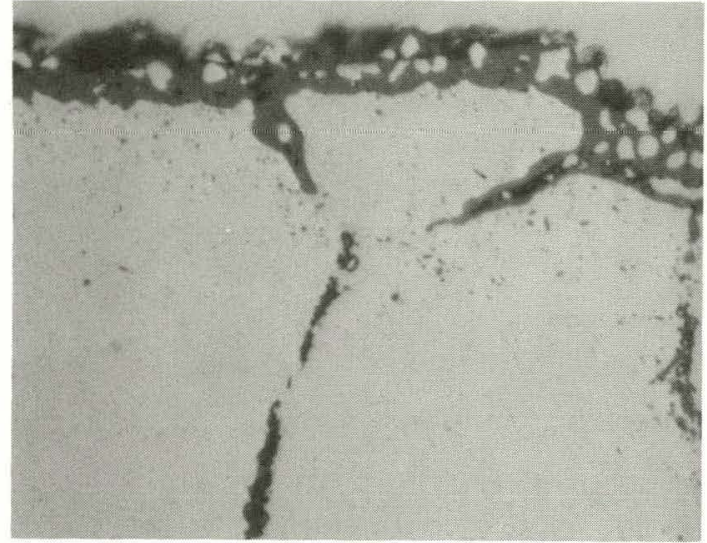

(d)

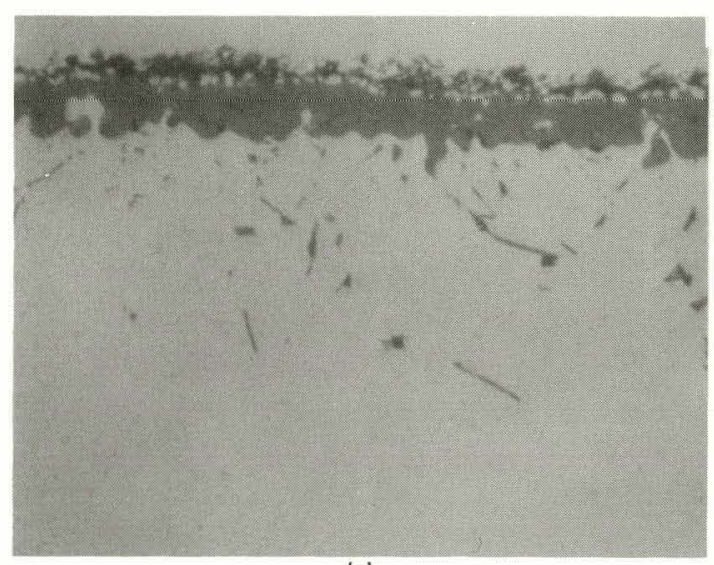

(e)

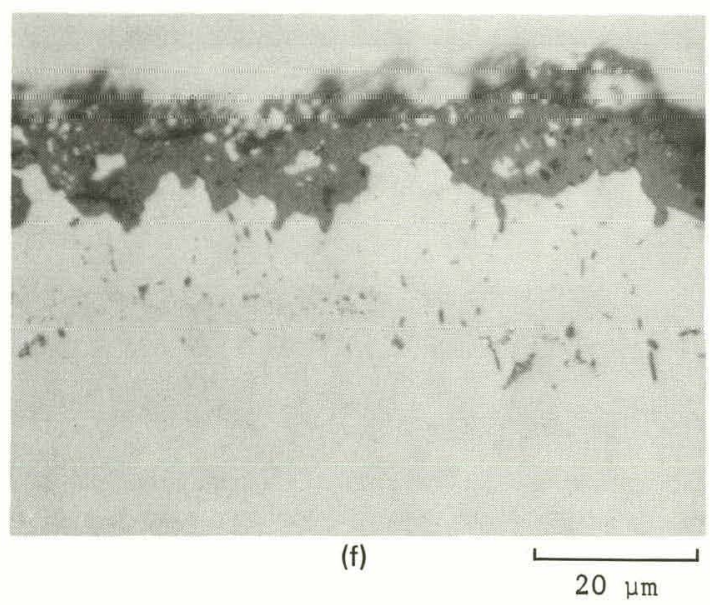

Fig. 32. Surface scales formed on Alloy $800 \mathrm{H}$ specimens exposed $3000 \mathrm{~h}$ at $900^{\circ} \mathrm{C}$ in controlled-impurity helium containing $500 \mu \mathrm{atm}$ $\mathrm{H}_{2} / 50$ uatm $\mathrm{CO} / 50$ atm $\mathrm{CH}_{4} /<0.5 \mu$ atm $\mathrm{H}_{2} \mathrm{O}$. Specimens were in the following conditions prior to exposure: preoxidized in air for (a) $1 \mathrm{~h}$, (b) $10 \mathrm{~h}$, and (c) $100 \mathrm{~h}$; (d) grit-blasted; (e) lapped; and (f) pickled. 


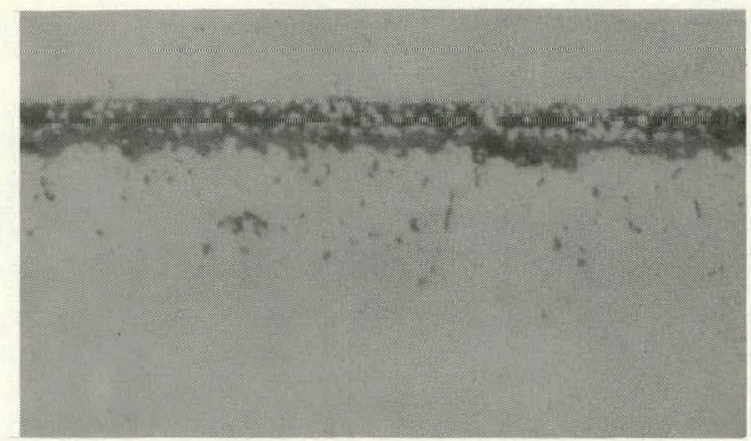

(a)

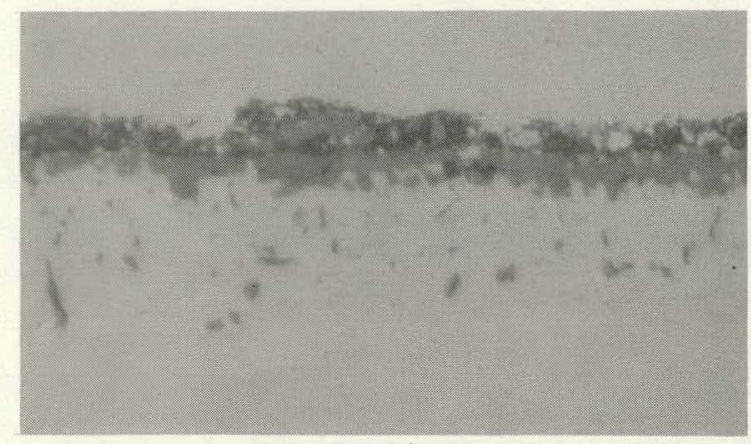

(b)

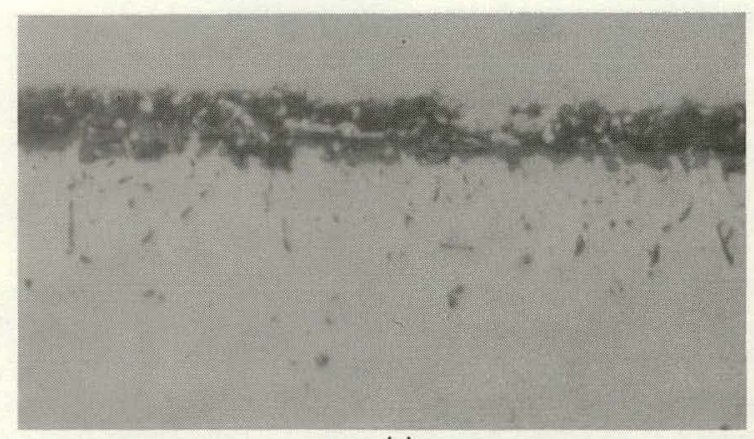

(c)

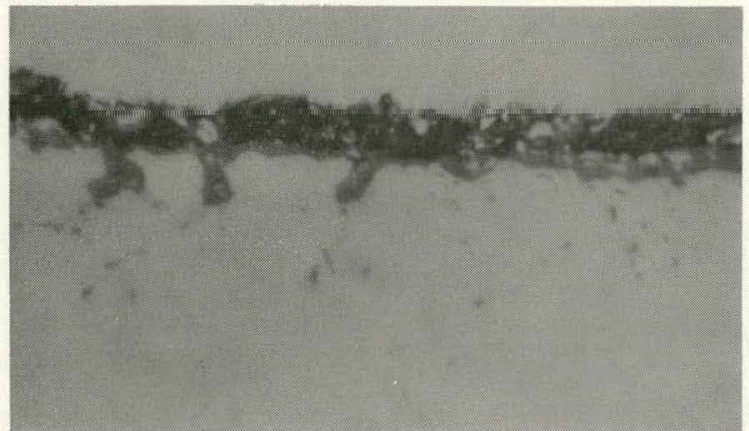

(d)

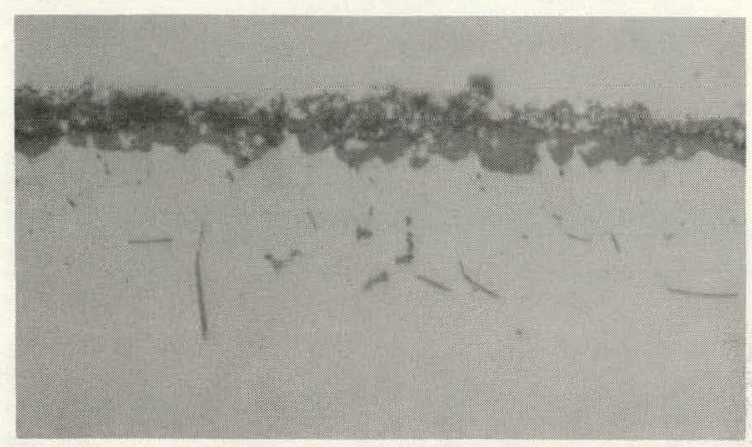

(e)

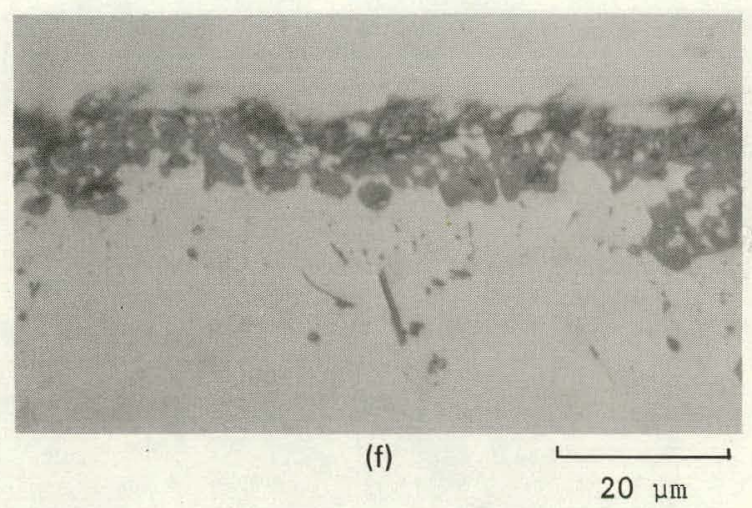

Fig. 33. Surface scales formed on Hastelloy X specimens exposed $3000 \mathrm{~h}$ at $900^{\circ} \mathrm{C}$ in controlled-impurity helium containing $500 \mu \mathrm{atm}$ $\mathrm{H}_{2} / 50 \mu \mathrm{atm} \mathrm{CO} / 50$ atm $\mathrm{CH}_{4} /<0.5 \mu \mathrm{atm} \mathrm{H}_{2} \mathrm{O}$. Specimens were in the following conditions prior to exposure: preoxidized in air for (a) $1 \mathrm{~h}$, (b) $10 \mathrm{~h}$, and (c) $100 \mathrm{~h}$; (d) grit-blasted; (e) lapped; and (f) pickled. 


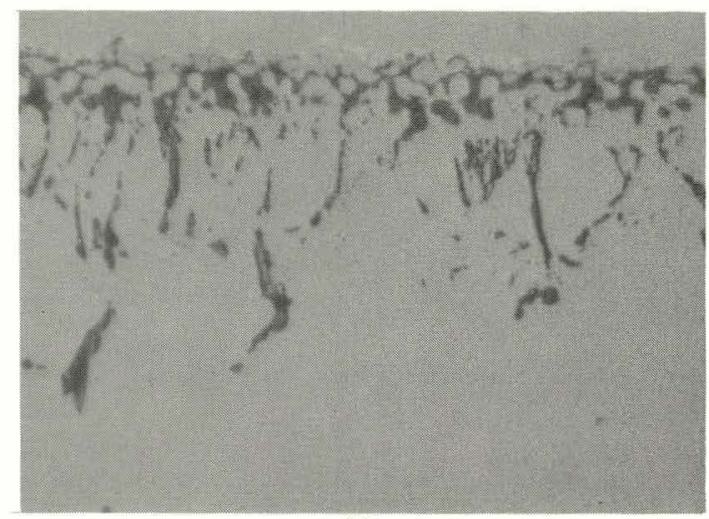

(a)

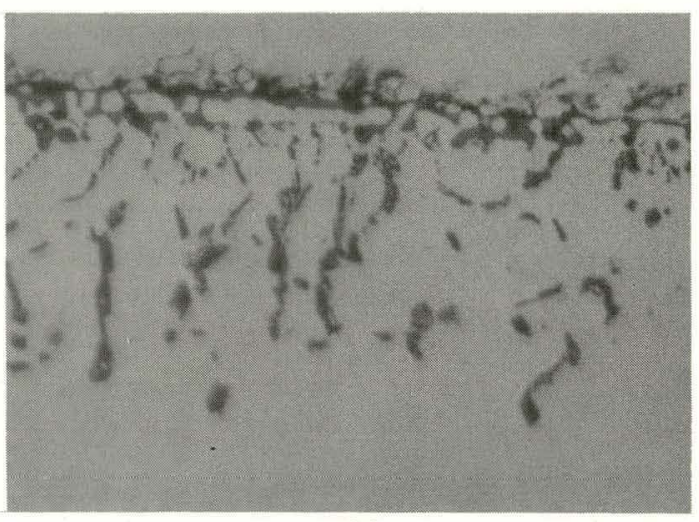

(b)

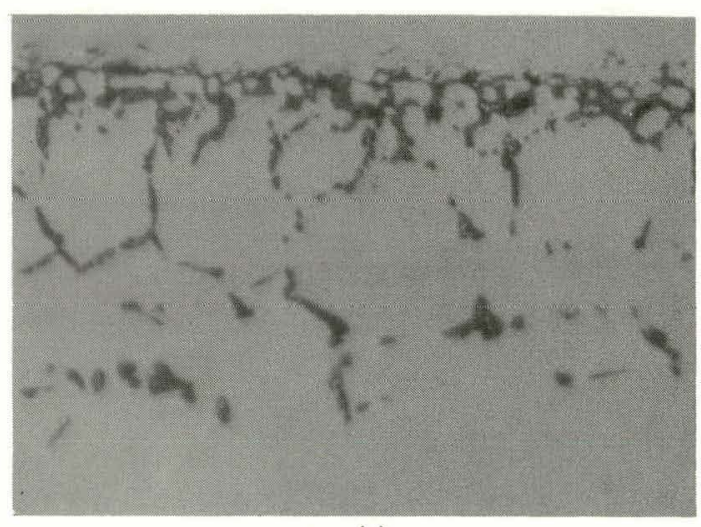

(c)

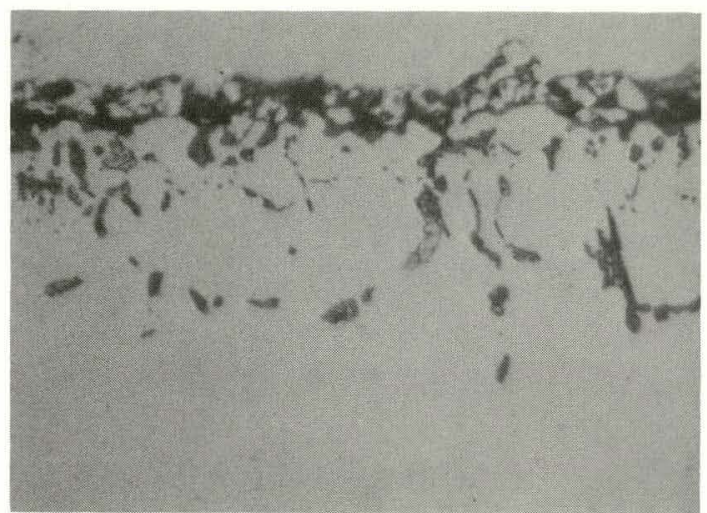

(d)

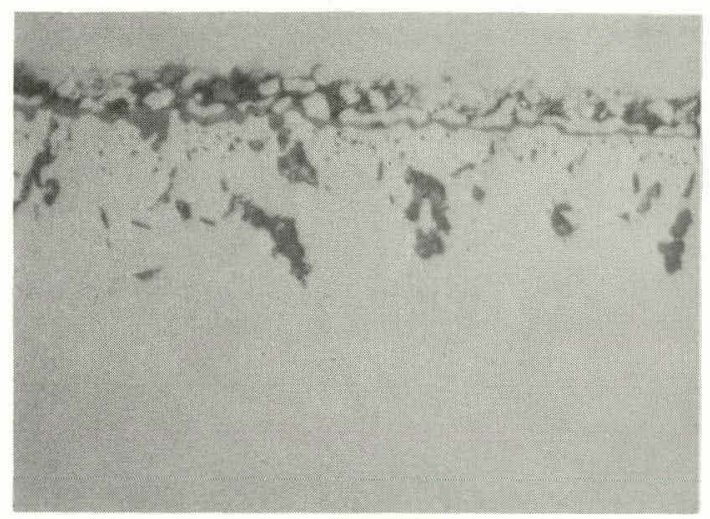

(e)

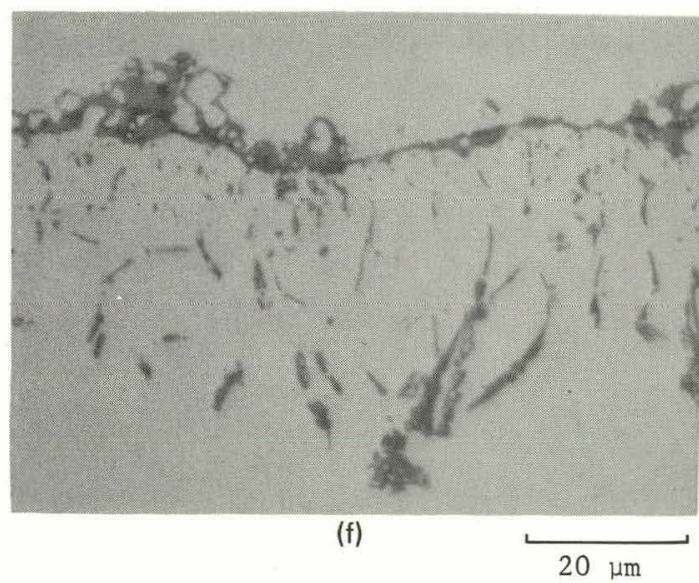

Fig. 34. Surface scales formed on Inconel 617 specimens exposed $3000 \mathrm{~h}$ at $900^{\circ} \mathrm{C}$ in controlled-impurity helium containing 500 klatm $\mathrm{H}_{2} / 50$ atm $\mathrm{CO} / 50$ atm $\mathrm{CH}_{4} /<0.5 \mu \mathrm{atm} \mathrm{H}_{2} \mathrm{O}$. Specimens were in the following conditions prior to exposure; preoxidized in air for (a) $1 \mathrm{~h}$, (b) $10 \mathrm{~h}$, and (c) $100 \mathrm{~h}$; (d) grit-blasted; (e) lapped; and (f) pickled. 
Figures 35 and 36 show the surface scales formed on IN 100 and IN 713LC. From Fig. 35, preoxidation promoted the internal oxidation of IN 100 during the controlled-impurity helium exposure. The grit-blasted and lapped specimens of IN 100 formed thin protective oxide scales in agreement with grit-blasted specimens studied in other simulated reactor exposure experiments (Refs. 1-5). Comparison of Figs. 29 and 36 shows that internal oxidation of the preoxidized IN 713LC specimens occurred during the controlled-impurity helium exposure. The final evolution of surface corrosion products on IN 713LC was similar for all cases of surface treatment.

Figure 37 shows that for HK 40 preoxidation treatments enhanced the internal oxidation susceptibility. Figure 31 shows little if any evidence of internal oxidation following the preoxidation treatments; therefore, all internal oxidation occurred during the controlled-impurity helium exposure. Again, scale formation was complex in all cases and consisted of duplex and triplex scales composed of oxides and carbides, independent of surface finish.

Very thin scales formed on MA 754, as shown in Fig. 38. Preoxidation treatments resulted in the formation of a slightly thicker oxide surface layer, but in general, scale characteristics were similar in a11 rases.

\subsection{CARBURIZATION}

Differential interference contrast techniques were employed to study the microstructural aspects of carburization during the controlled-impurity helium exposures. The ingress of carbon results in the intergranular and intragranular precipitation of carbides in a zone near the surface and extending into the specimen to a depth that is a function of exposure time, temperature, environment, alloy chemistry, and surface finish (Refs. 1-5, 11), 


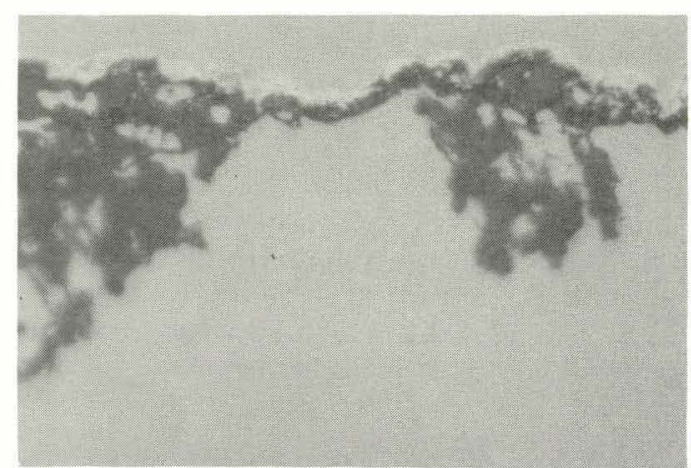

(a)

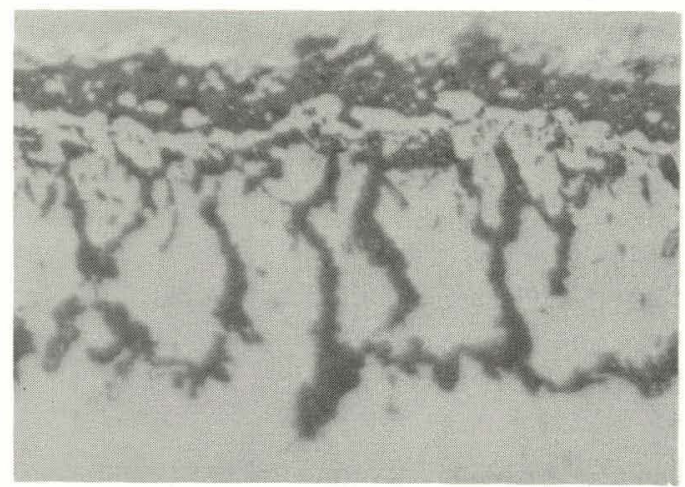

(b)

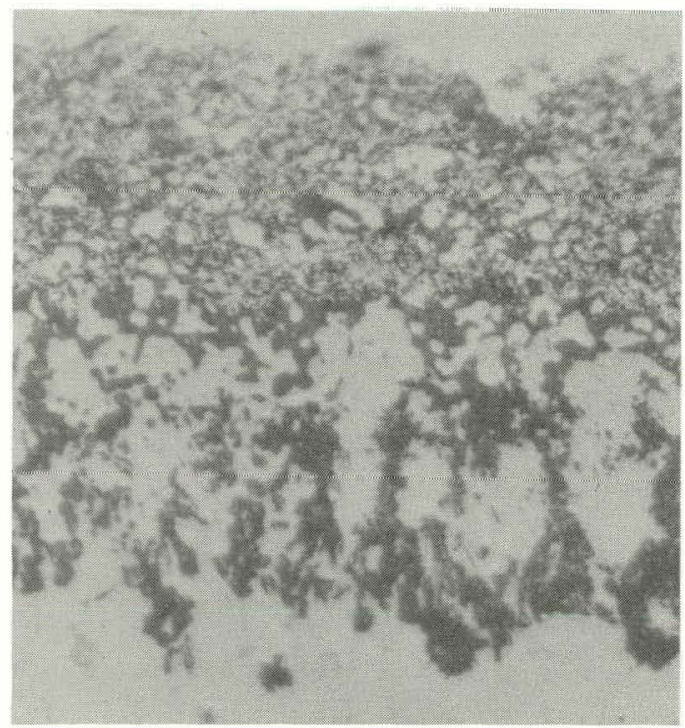

(c)

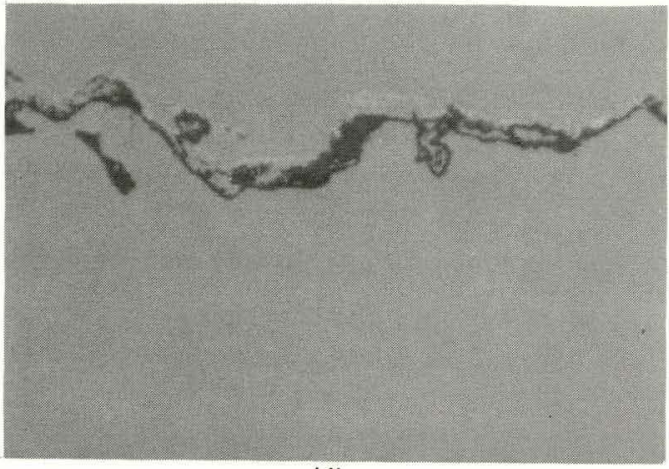

(d)

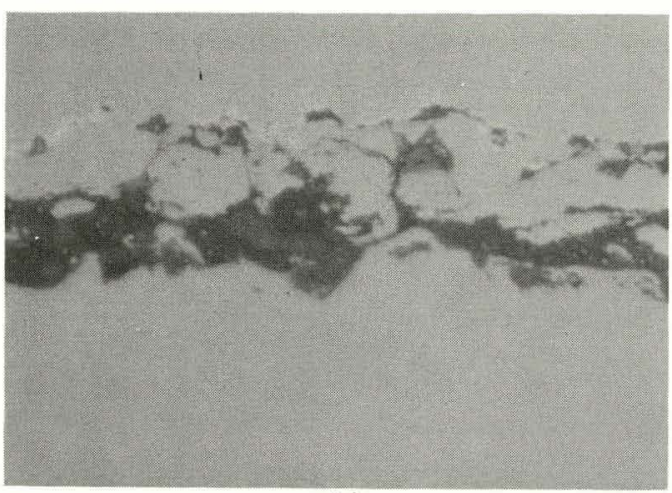

(e)

Fig. 35. Surface scales formed on IN 100 specimens exposed $3000 \mathrm{~h}$ at $900^{\circ} \mathrm{C}$ in controlled-impurity helium containing $500 \mu \mathrm{atm} \mathrm{H}_{2} / 50 \mu \mathrm{atm}$ $\mathrm{CO} / 50 \mu \mathrm{atm} \mathrm{CH}_{4} /<0.5 \mu \mathrm{atm} \mathrm{H}_{2} \mathrm{O}$. Specimens were in the following conditions prior to exposure: preoxidized in air for (a) $1 \mathrm{~h}$, (b) $10 \mathrm{~h}$, and (c) $100 \mathrm{~h}$; (d) grit-blasted; and (e) pickled. 


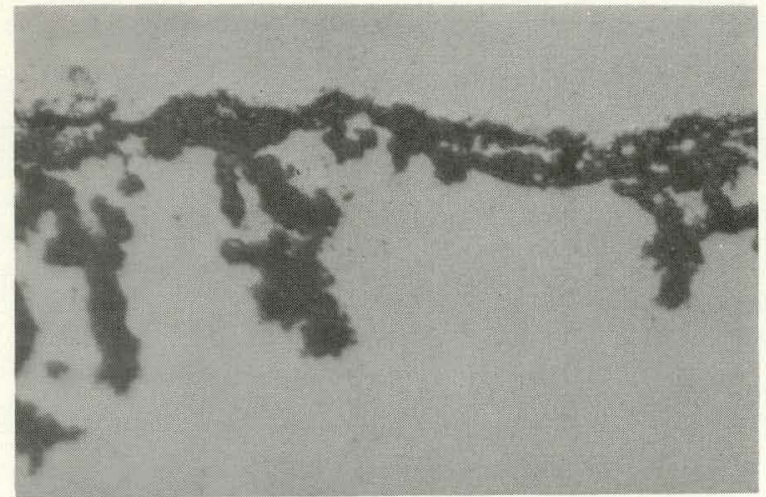

(a)

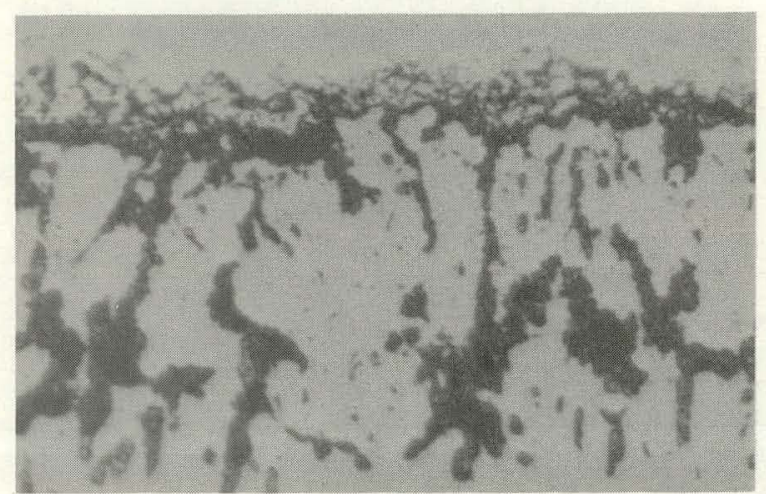

(b)

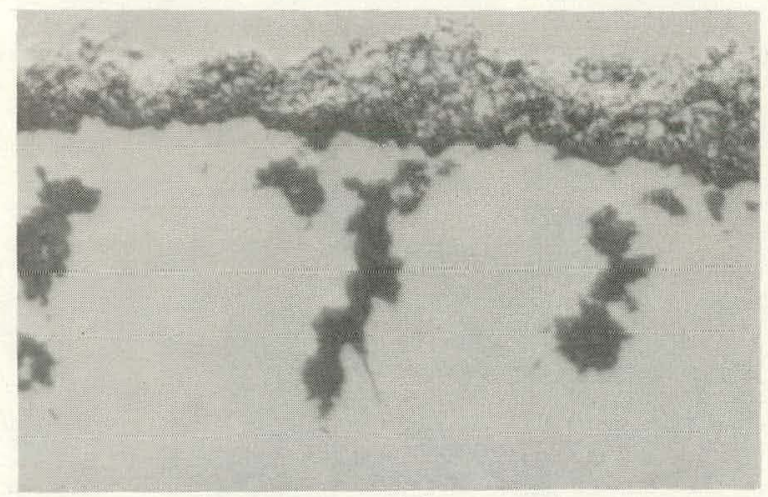

(c)

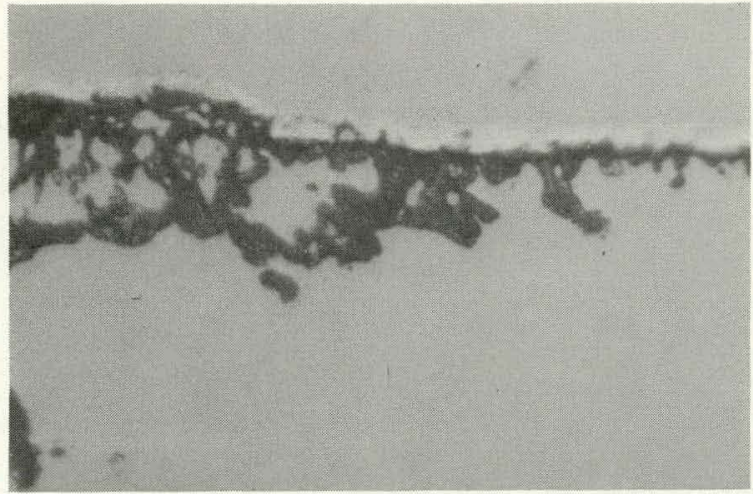

(d)

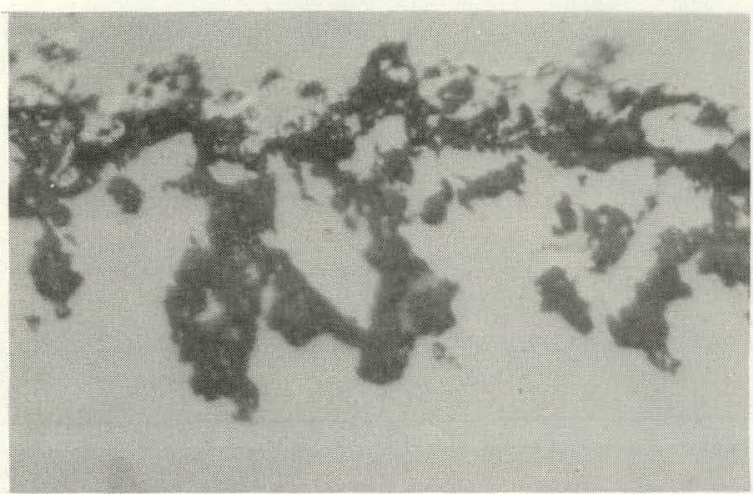

(e)

$$
20 \mu \mathrm{m}
$$

Fig. 36. Surface scales formed on IN 713LC specimens exposed $3000 \mathrm{~h}$ at $900^{\circ} \mathrm{C}$ in controlled-impurity helium containing $500 \mu \mathrm{atm} \mathrm{H}_{2} /$. $50 \mu \mathrm{atm} \mathrm{CO} / 50 \mu \mathrm{atm} \mathrm{CH}_{4} /<0.5 \mu \mathrm{atm} \mathrm{H}_{2} \mathrm{O}$. Specimens were in the following conditions prior to exposure: preoxidized in air for (d) $1 \mathrm{~h}$, (b) $10 \mathrm{~h}$, and (c) $100 \mathrm{~h}$; (d) grit-blasted; and (e) lapped. 


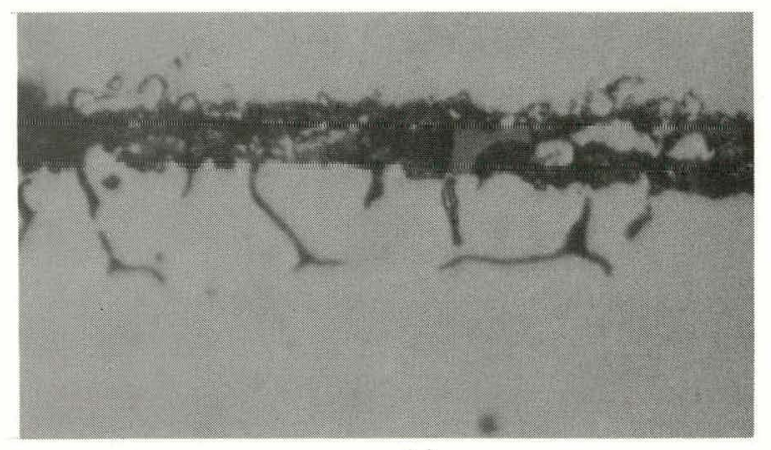

(a)

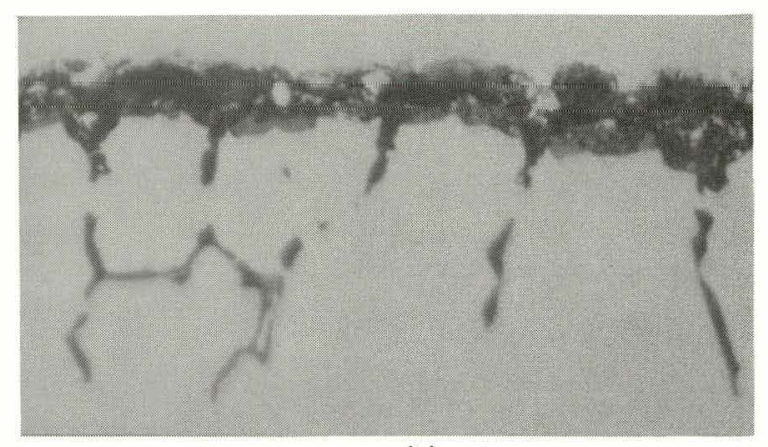

(b)

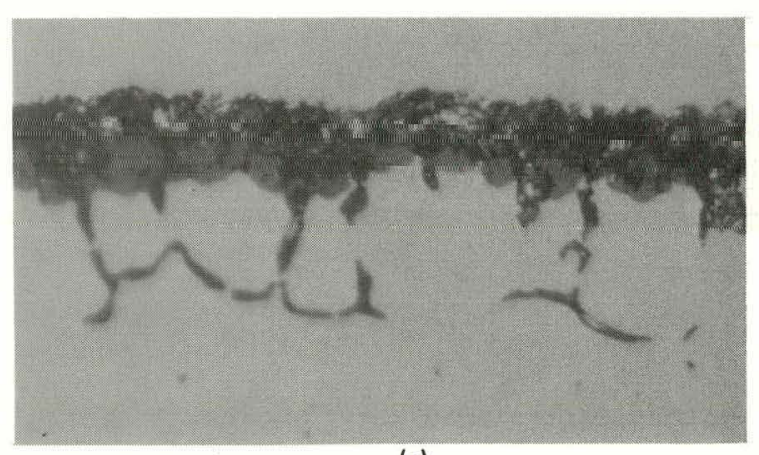

(c)

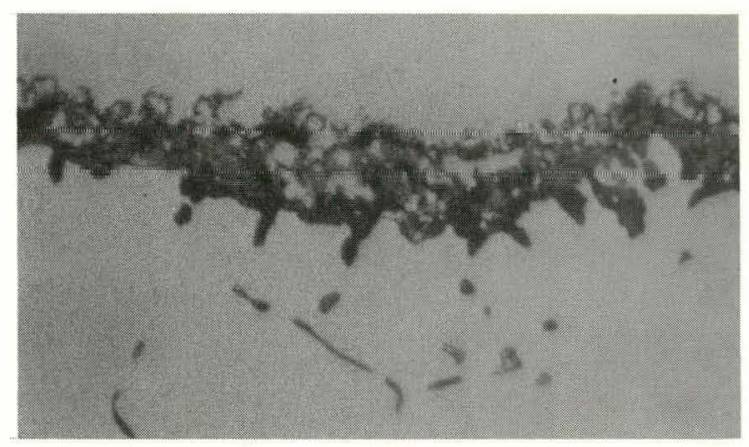

(d)

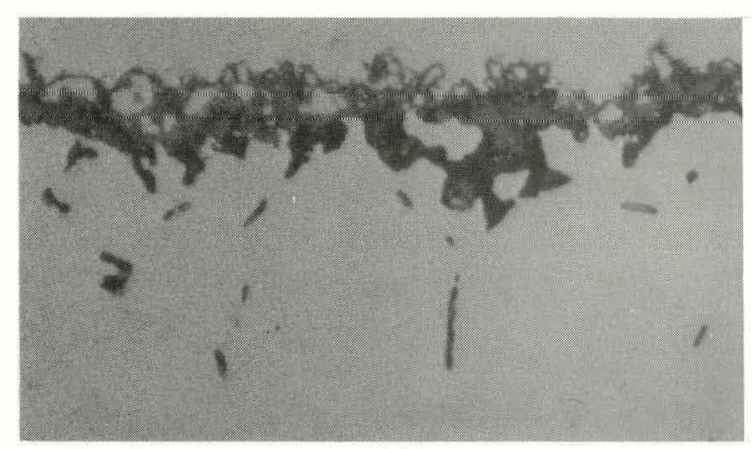

(e)

$20 \mu \mathrm{m}$

Fig. 37. Surface scales formed on $\mathrm{HK} 40$ specimens exposed $3000 \mathrm{~h}$ at $900^{\circ} \mathrm{C}$ in controlled-impurity helium containing $500 \mu \mathrm{atm} \mathrm{H}_{2} / 50 \mu \mathrm{atm}$ $\mathrm{CO} / 50$ matm $\mathrm{CH}_{4} /<0.5 \mu \mathrm{atm} \mathrm{H}_{2} \mathrm{O}$. Specimens were in the following conditions prior to exposure: preoxidized in air for (a) $1 \mathrm{~h}$, (b) $10 \mathrm{~h}$, and (c) $100 \mathrm{~h}$; (d) grit-blasted; and (e) lapped. 


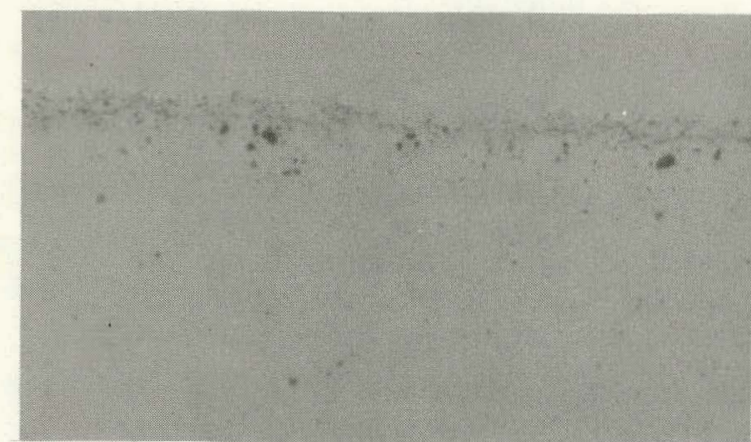

(a)

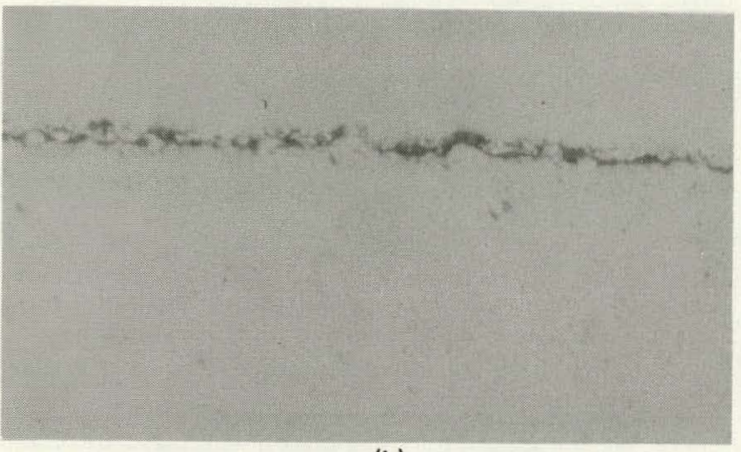

(b)

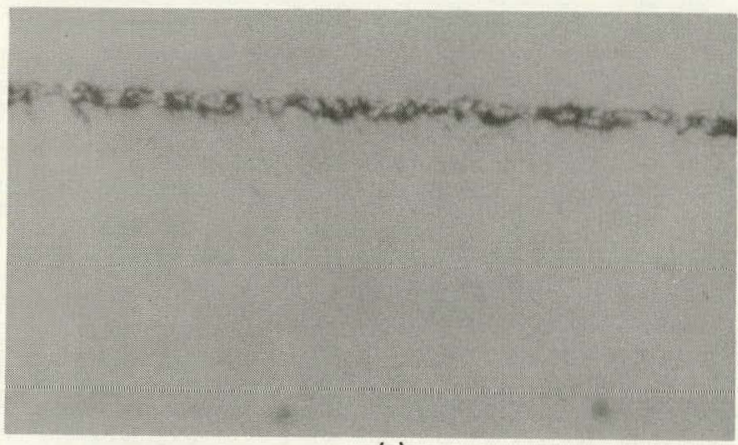

(c)

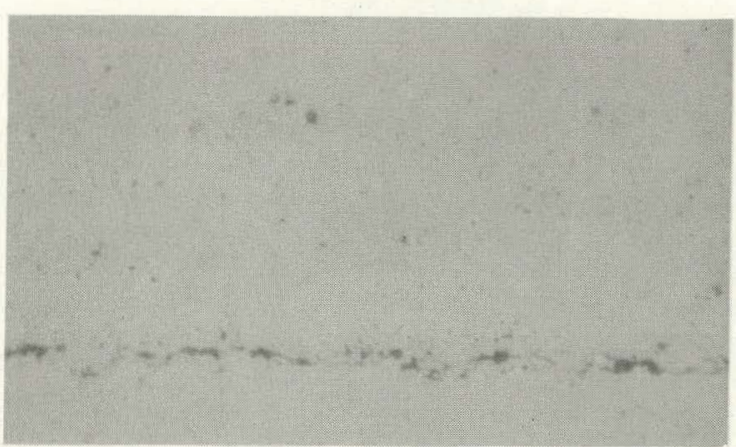

(d)

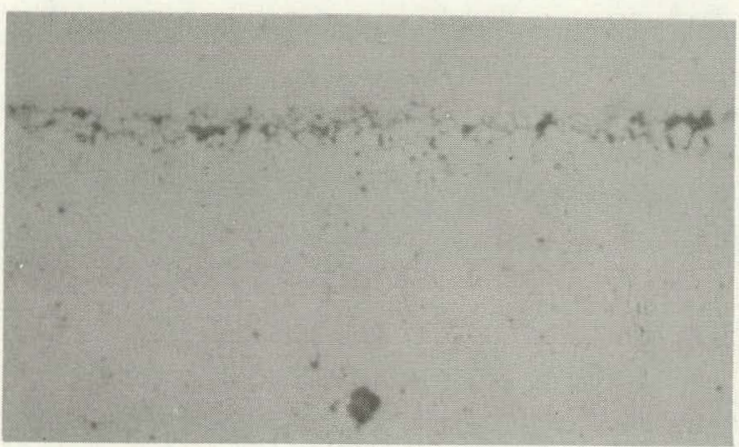

(e)

Fig. 38. Surface scales formed on MA 754 specimens exposed $3000 \mathrm{~h}$ at $900^{\circ} \mathrm{C}$ in controlled-impurity helium containing $500 \mu \mathrm{atm} \mathrm{H}_{2} / 50 \mu \mathrm{atm}$ $\mathrm{CO} / 50$ Hatm $\mathrm{CH}_{4} /<0.5$ Hatm $\mathrm{H}_{2} \mathrm{O}$. Specimens were in the following conditions prior to exposure: preoxidized in air for (a) $1 \mathrm{~h}$, (b) $10 \mathrm{~h}$, and (c) $100 \mathrm{~h}$; (d) lapped; and (e) pickled. 
In Fig. 39 a comparison is made between Alloy $800 \mathrm{H}$ specimens given a preoxidation treatment and those given a pickling treatment. Figure 39a is typical of the microstructures observed for the preoxidized specimens. Thermal aging, which has occurred, resulted in the formation of generally discontinuous grain-boundary networks of $\mathrm{M}_{23} \mathrm{C}_{6}$ (Ref. 12). The pickled specimen, shown in Fig. 39a, contained grain-boundary carbide networks, which appeared to be more continuous than in the preoxidized specimen, and also showed an increase in the density of intragranular carbides. These intragranular carbides sometimes appeared as Widmänstatten precipitates with very clearly defined habit planes. In the case of the pickled, grit-blasted, or lapped specimens, twin boundaries were decorated with carbides to a greater extent than in those specimens given preoxidation treatments. Metallographically, it is more difficult to establish carburization depths in Alloy $800 \mathrm{H}$ since carburization results primarily in the intergranular precipitation of $\mathrm{M}_{23} \mathrm{C}_{6}$ carbides, as does thermal aging reactions at $900^{\circ} \mathrm{C}$ (Refs. 1-5, 12). It is therefore more difficult to distinguish between thermal aging effects and enhanced precipitation as a result of carburization.

In the case of Hastelloy $x$, the thermal aging reactions result in the precipitation of $\mathrm{M}_{6} \mathrm{C}$ carbides, whereas carburization results in the precipitation of $\mathrm{M}_{23} \mathrm{C}_{6}$-type carbides. The inherent hardness differences, leading to differences in "relief" for polished specimens, make a technique such as differential interference contrast invaluable in interpreting and distinguishing carburization effects. Figure $40 \mathrm{~b}$ shows an example of carburization in Hastelloy X. In Fig. 40a no carburization was observed in the specimen preoxidized $10 \mathrm{~h}$. This was typical of the specimens preoxidized 1 and $100 \mathrm{~h}$ as well. Carburization, morphologically similar to that observed in Fig. 40b, occurred in the lapped and gritblasted specimens also.

Figure 41 shows examples of carburization observed for Incone1 617. Although the specimen in Fig. 41a was preoxidized, little apparent benefit was gained with respect to inhibiting carbon ingress. A slightly lower 

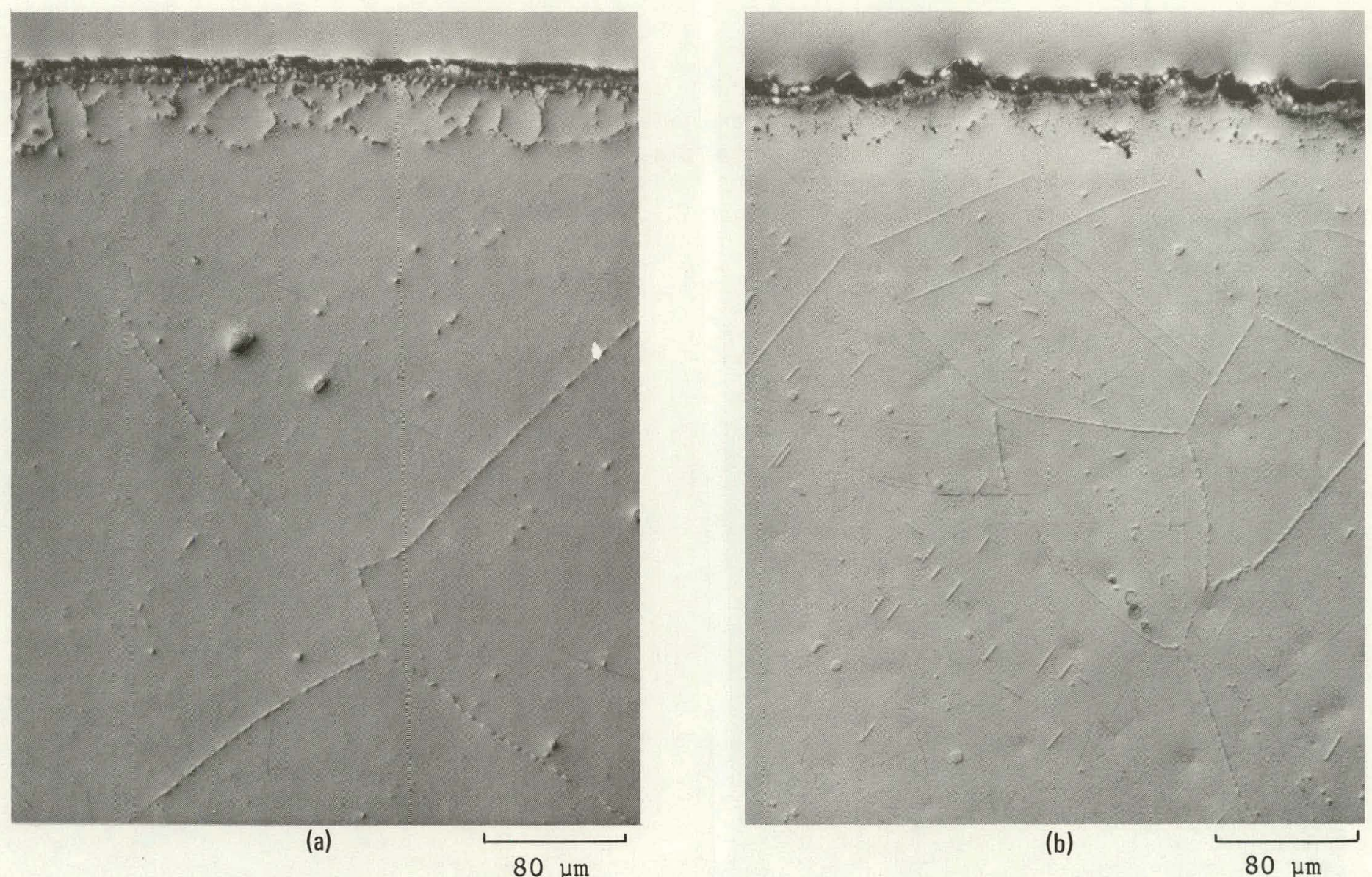

Fig. 39. Differential interference contrast photomicrographs showing Alloy $800 \mathrm{H}$ specimens exposed $3000 \mathrm{~h}$ Delium containing $500 \mu \mathrm{atm} \mathrm{H} / 50 \mu \mathrm{atm} \mathrm{CO} / 50 \mu \mathrm{atm} \mathrm{CH}_{4} /<0.5 \mu \mathrm{atm}$ $\mathrm{H}_{2} \mathrm{O}$. Prior to exposure surface condition was (a) preoxidized $10 \mathrm{~h}$ and (b) pickled. 

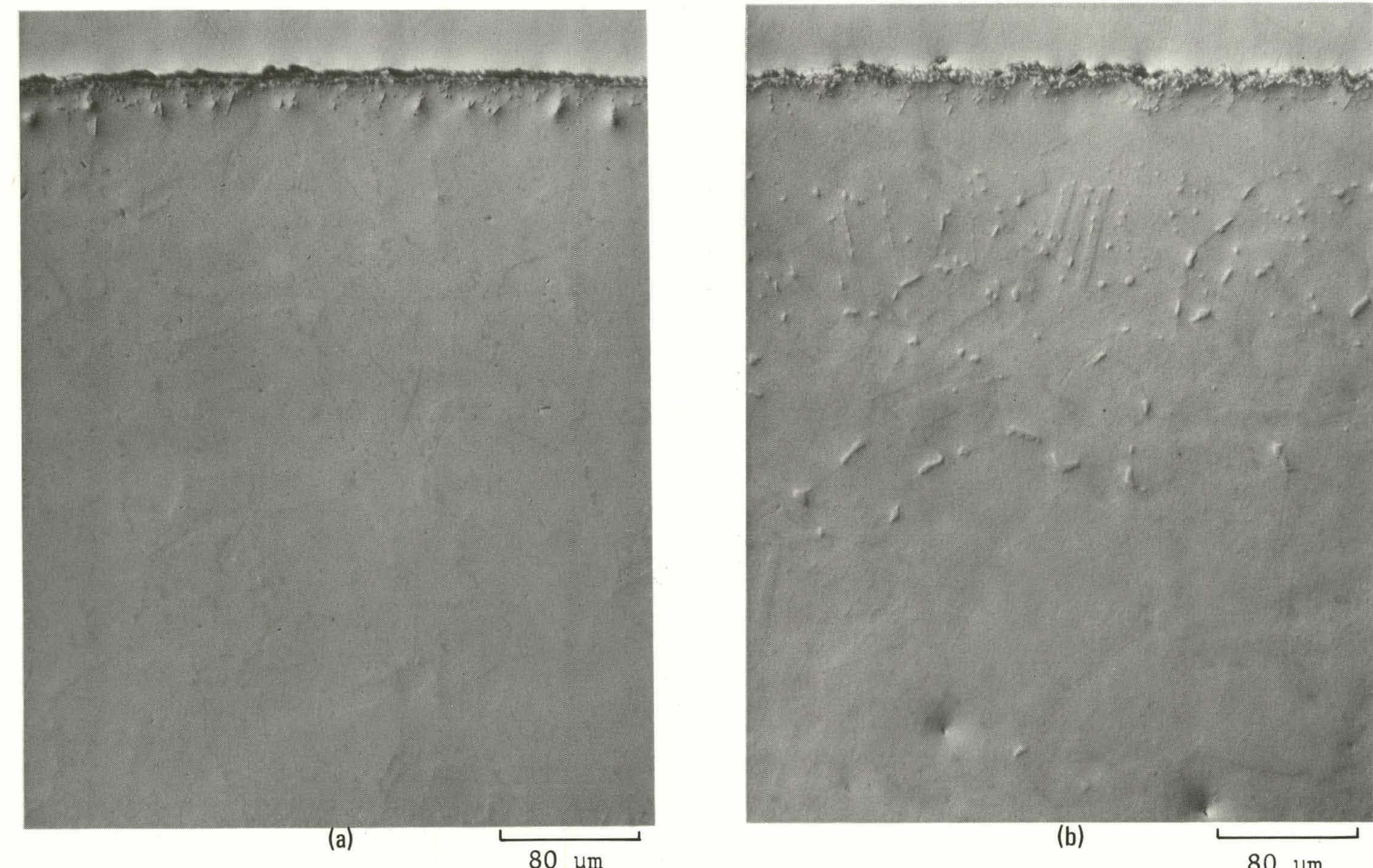

(b)

$80 \mu \mathrm{m}$

Fig. 40. Differential interference contrast photomicrographs showing Hastelloy X specimens exposed $3000 \mathrm{~h}$ at $900^{\circ} \mathrm{C}$ in controlled-impurity helium containing $500 \mu \mathrm{atm} \mathrm{H}_{2} / 50 \mu \mathrm{atm} \mathrm{CO} / 50 \mu \mathrm{atm}$ $\mathrm{CH}_{4} /<0.5$ Matm $\mathrm{H}_{2} \mathrm{O}$. Prior to exposure specimen surface condition was (a) preoxidized $10 \mathrm{~h}$ and (b) pickled. 

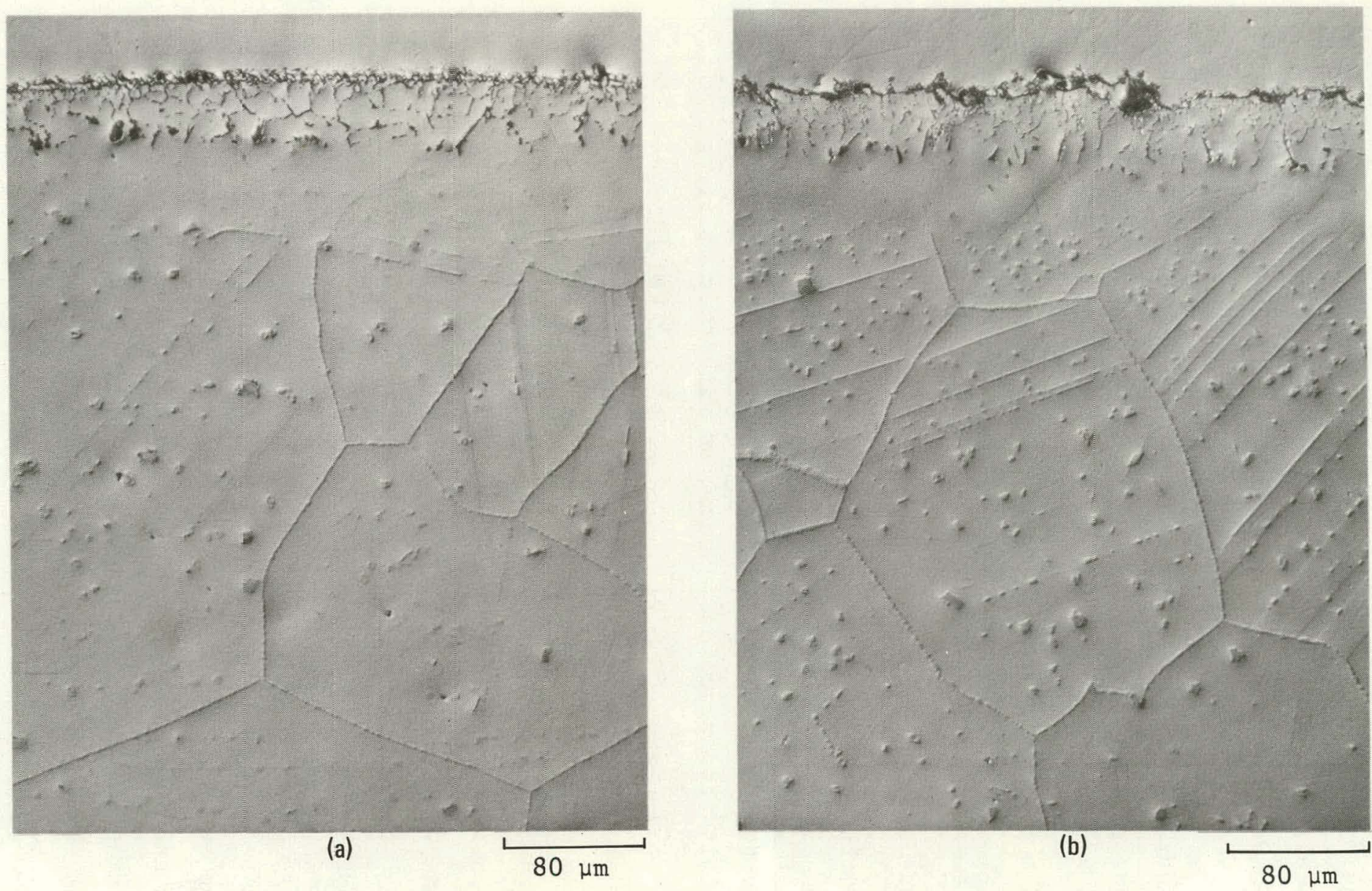

Fig. 41. Differential interference contrast photomicrographs showing Incone1 617 specimens exposed $3000 \mathrm{~h}$ at $900^{\circ} \mathrm{C}$ in controlled-impurity helium containing $500 \mu \mathrm{atm} \mathrm{H}_{2} / 50 \mu \mathrm{atm} \mathrm{CO} / 50 \mu \mathrm{atm}$ $\mathrm{CH}_{4} /<0.5 \mu \mathrm{atm} \mathrm{H}_{2} \mathrm{O}$. Prior to exposure surface condition was (a) preoxidized $100 \mathrm{~h}$ and (b) pickled. 
intragranular carbide density was observed in the carburized zone for the preoxidized specimens as compared to the lapped, grit-blasted, or pickled specimens. This behavior can probably be attributed to the preoxidized scales being somewhat effective barriers, but the discontinuity of the scales still permitted some carbon ingress.

Interestingly enough, preoxidation treatments seemed to increase the severity of carburization for the cast superalloys. The preoxidized specimens of IN 100 and IN 713LC (Figs. 42 and 43) showed increased carbide densities and more continuous intergranular carbide networks than those observed for either lapped or grit-blasted specimens (1apped specimens are shown).

Figure 44 shows differential interference contrast photographs typical of those observed for HK 40 and MA 754, independent of surface condition. The high carbon concentration of $\mathrm{HK} 40(\sim 0.4 \%)$ leads to difficulty in distinguishing carbide precipitation reactions associated with thermal aging from those associated with carburization. It is apparent from Fig. $44 a$ that the carburized zone in $\mathrm{HK} 40$ had a heavier density of intragranular carbides, although this effect was not consistently observable. In the case of MA 754, decarburization has been observed upon exposure to simulated reactor helium environments (Refs. 4,5); therefore, no morphological effects are associated with carburization.

\subsection{BULK CARBON CONTENT ANALYSES}

As a means of comparison and to provide insight as to the severity of the carburization phenomenon, bulk carbon concentrations were determined for the post-exposure specimens and for specimens prior to testing. For all the alloys, the change of carbon concentration varied with the particular surface condition. The carbon concentrations as a function of surface condition are shown in Figs. 45 through 51. 


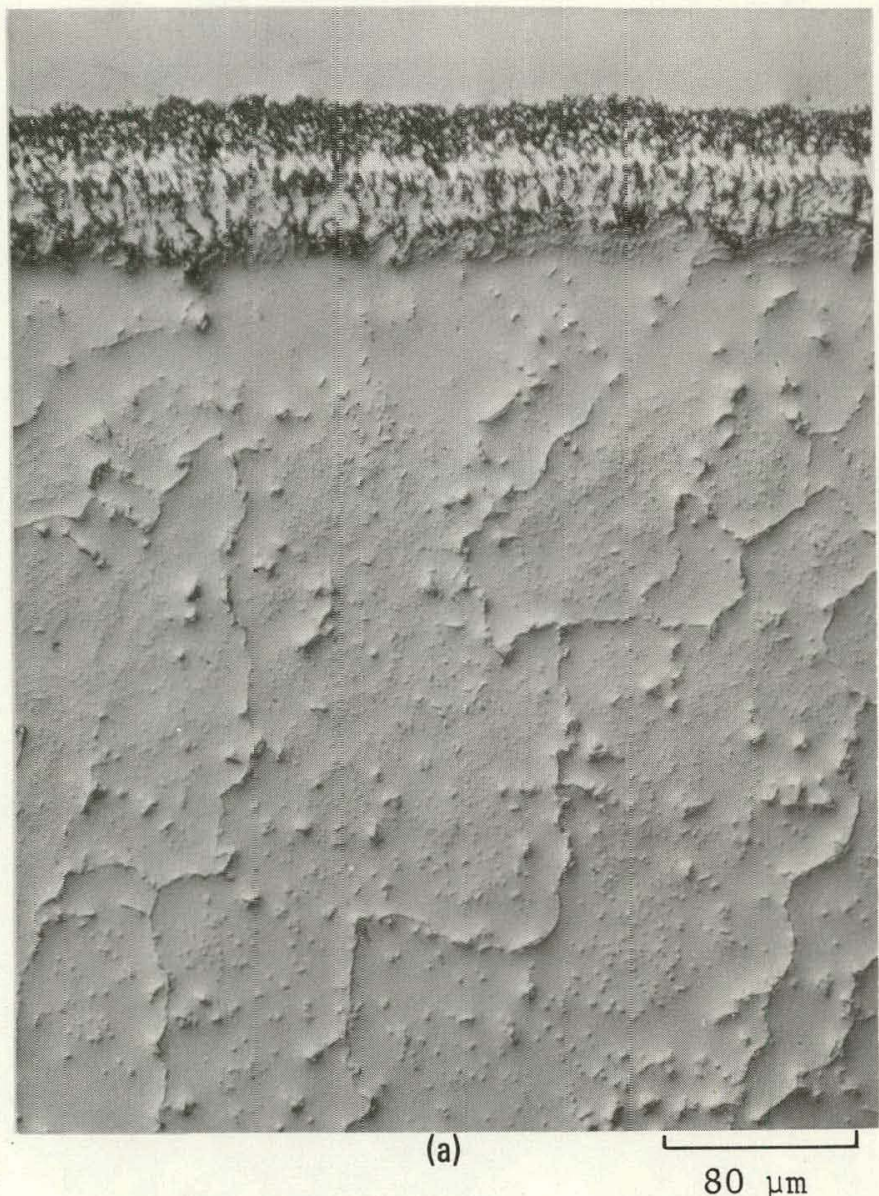

$80 \mu \mathrm{m}$

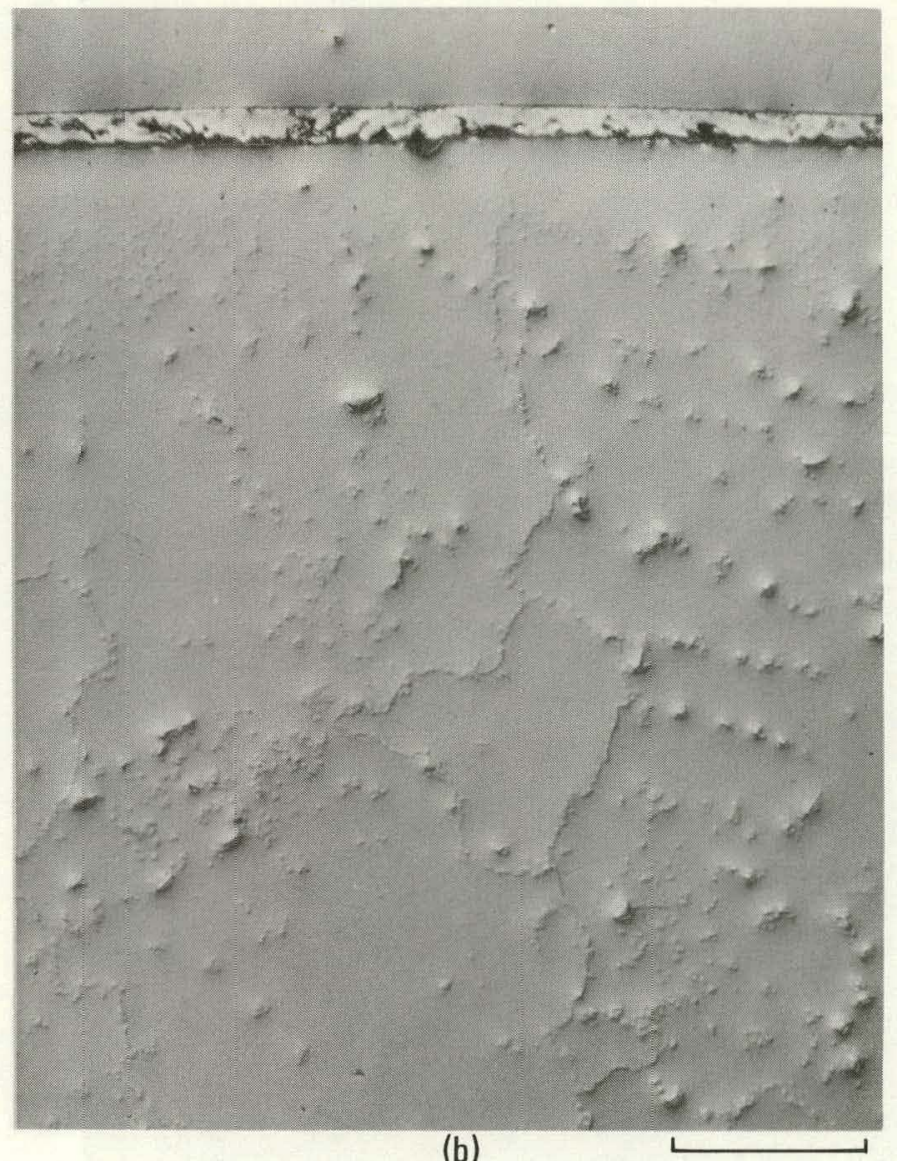

$80 \mu \mathrm{m}$

Fig. 42. Differential interference contrast photomicrographs showing IN 100 specimens exposed $3000 \mathrm{~h}$

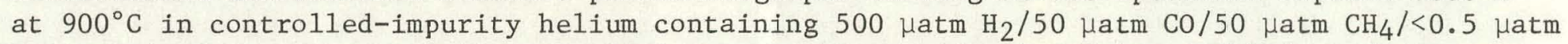
$\mathrm{H}_{2} \mathrm{O}$. Prior to exposure specimen condition was (a) preoxidized $100 \mathrm{~h}$ and (b) lapped. 


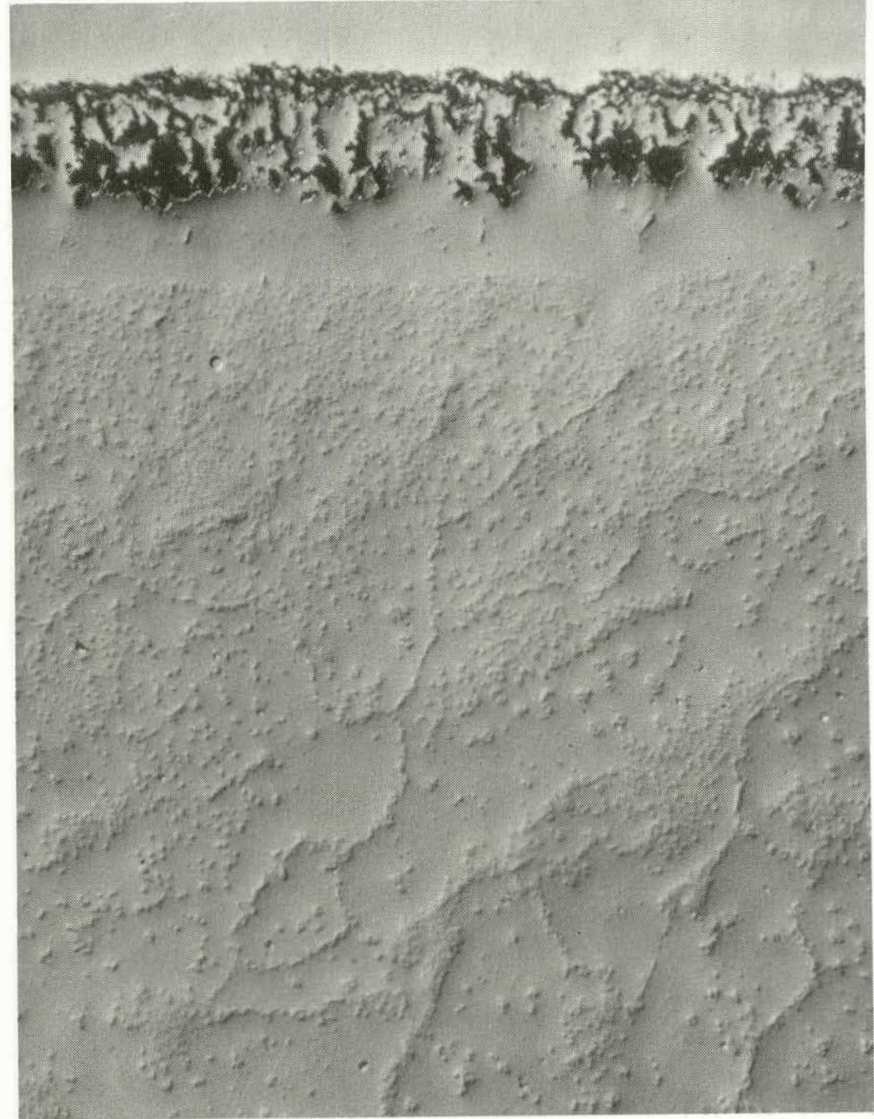

(a)

$80 \mu \mathrm{m}$

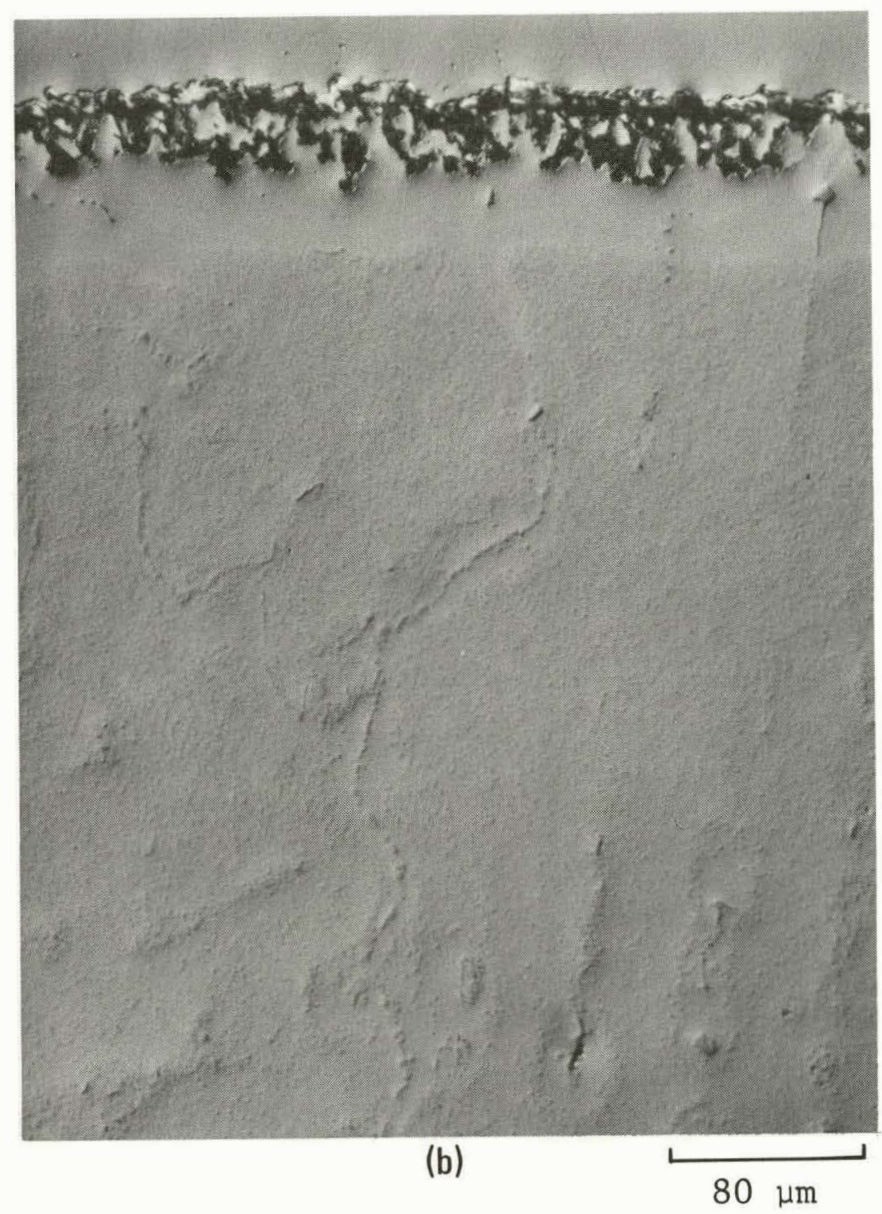

Fig. 43. Differential interference contrast photomicrographs showing IN 713LC specimens exposed $3000 \mathrm{~h}$ at $900^{\circ} \mathrm{C}$ in controlled-impurity helium containing $500 \mu \mathrm{atm} \mathrm{H}_{2} / 50 \mu \mathrm{atm} \mathrm{CO} / 50 \mu \mathrm{atm} \mathrm{CH}_{4} /<0.5 \mu \mathrm{atm}$ $\mathrm{H}_{2} \mathrm{O}$. Prior to exposure specimen condition was (a) preoxidized $10 \mathrm{~h}$ and (b) lapped. 


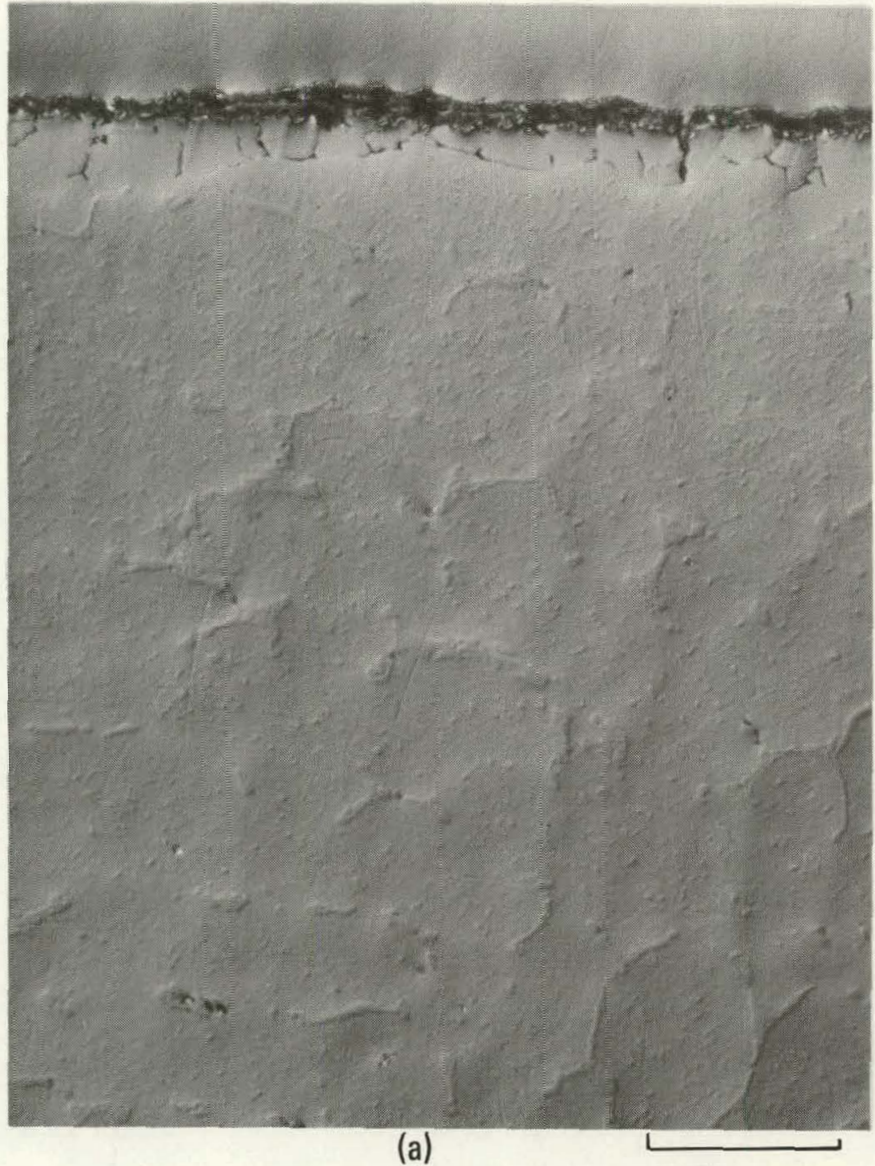

$80 \mu \mathrm{m}$

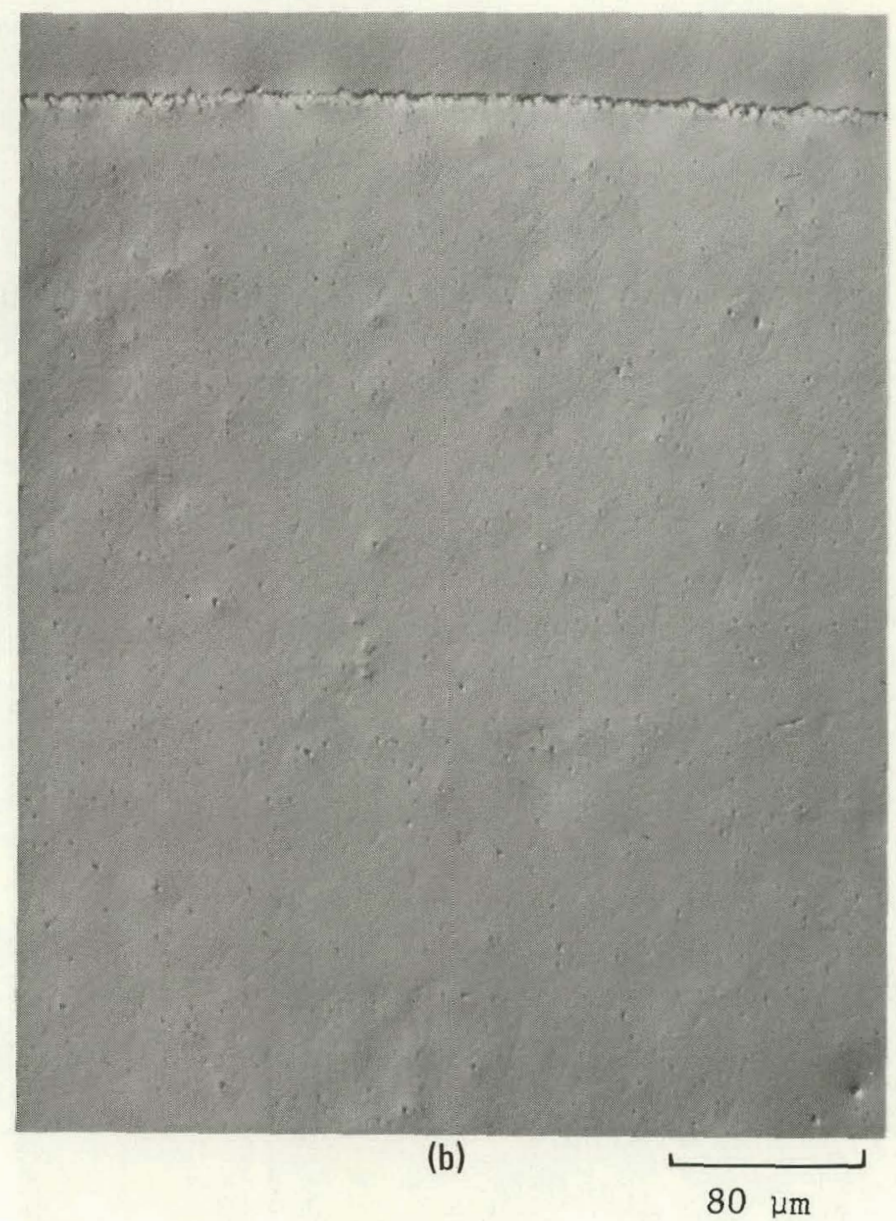

$80 \mu \mathrm{m}$

Fig. 44. Differential interference contrast photomicrographs showing (a) HK 40 and (b) MA 754 specimens exposed $3000 \mathrm{~h}$ at $900^{\circ} \mathrm{C}$ in controlled-impurity helium containing $500 \mu \mathrm{atm} \mathrm{H}_{2} / 50 \mu \mathrm{rtm}$ $\mathrm{CO} / 50$ Hatm $\mathrm{CH}_{4} /<0.5 \mu \mathrm{atm} \mathrm{H}_{2} \mathrm{O}$. Prior to exposure both specimens were preoxidized ${ }^{2} 10 \mathrm{~h}$. 


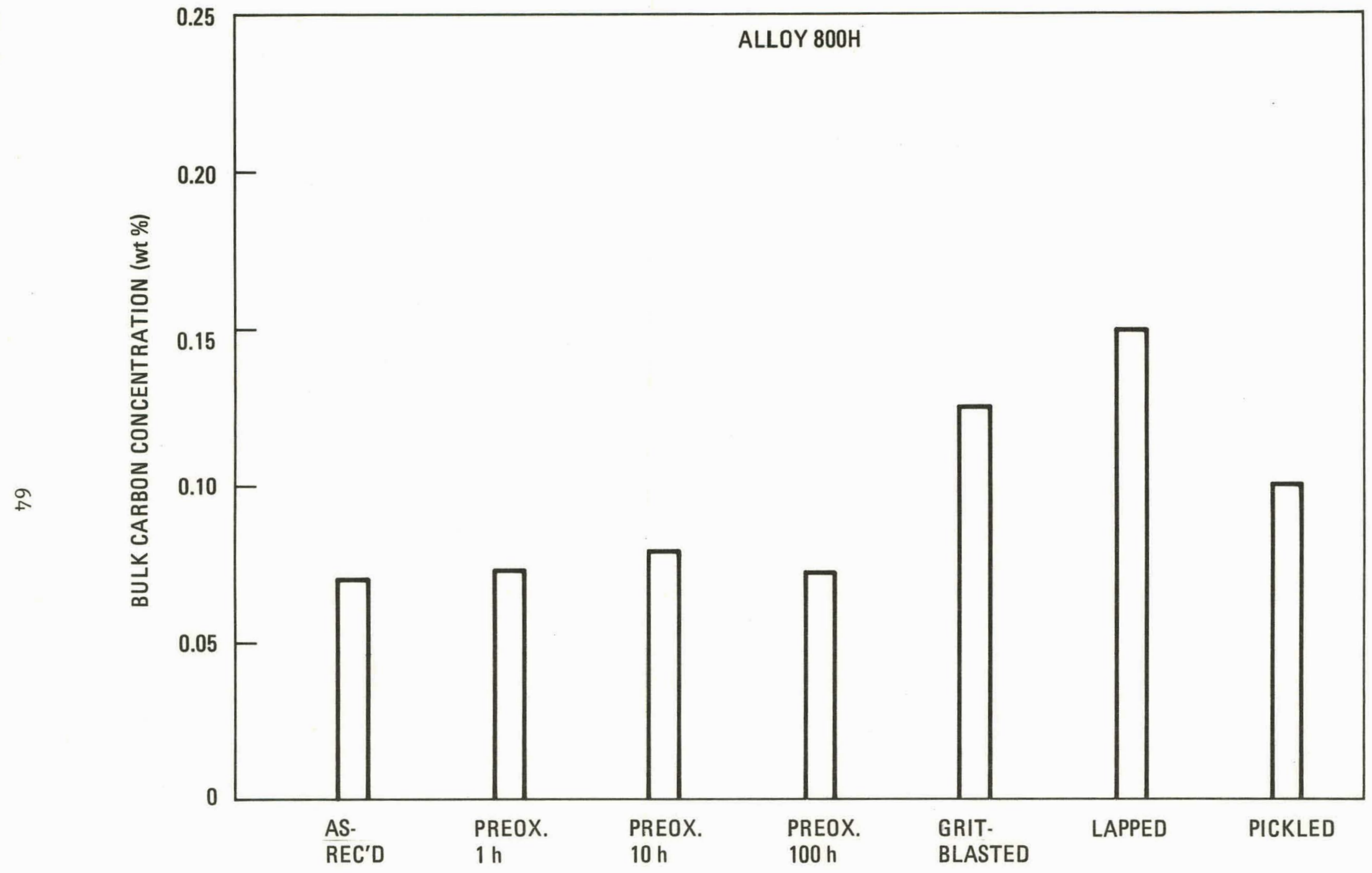

Fig. 45. Bulk carbon concentrations for Alloy $800 \mathrm{H}$ specimens following exposure for $3000 \mathrm{~h}$ at $900^{\circ} \mathrm{C}$ to controlled-impurity helium containing $500 \mu \mathrm{atm} \mathrm{H}_{2} / 50 \mu \mathrm{atm} \mathrm{CO} / 50 \mu \mathrm{atm}$ $\mathrm{CH}_{4} /<0.5$ Hatm $\mathrm{H}_{2} \mathrm{O}$ 


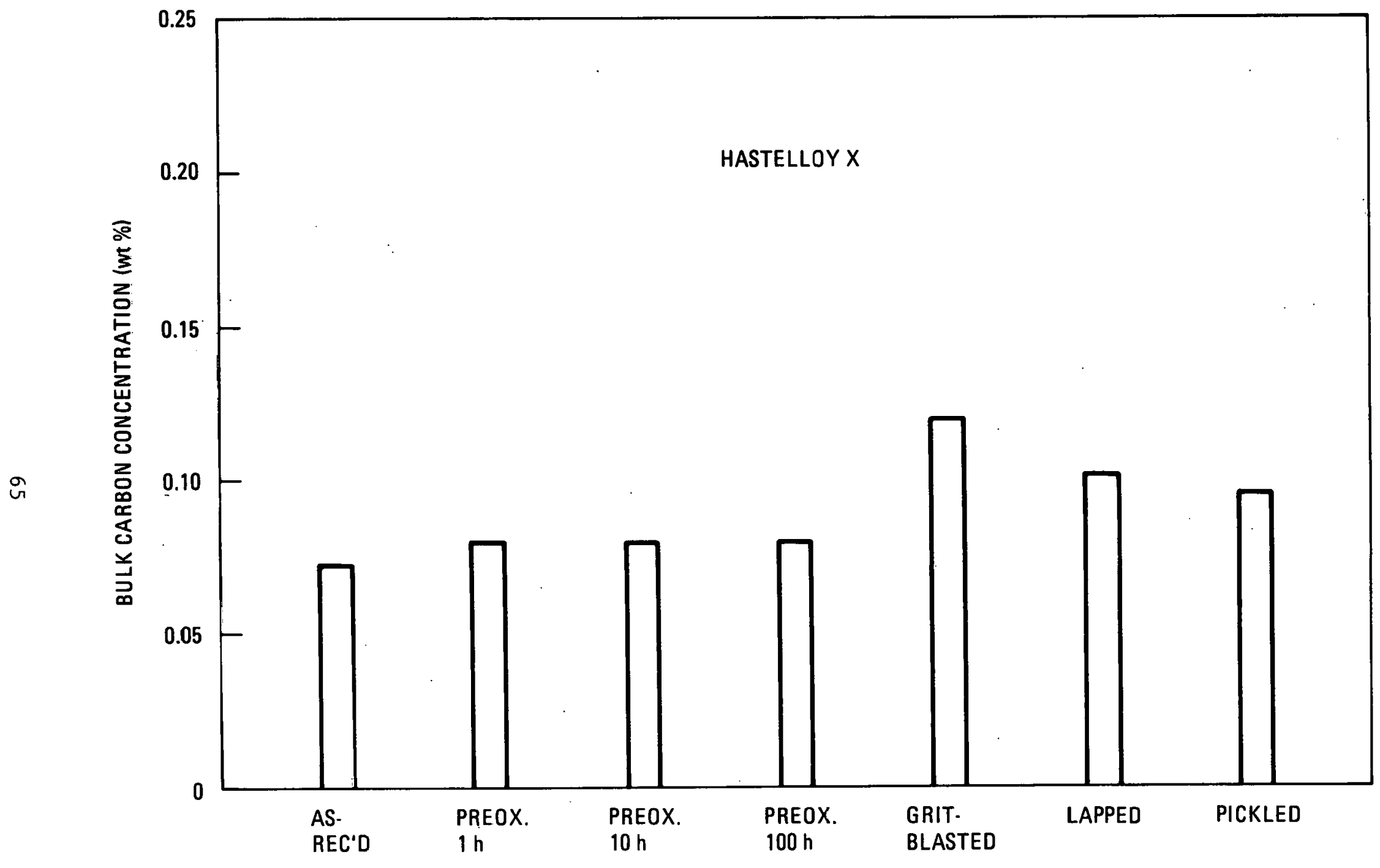

Fig. 46. Bulk carbon concentrations for Hastelloy X specimens following exposure for $3000 \mathrm{~h}$ at $900^{\circ} \mathrm{C}$ to controlled-impurity helium containing $500 \mu \mathrm{atm} \mathrm{H}_{2} / 50 \mu \mathrm{atm} \mathrm{CO} / 50 \mu \mathrm{atm} \mathrm{CH}_{4} /<0.5 \mu \mathrm{atm} \mathrm{H}_{2} \mathrm{O}$ 


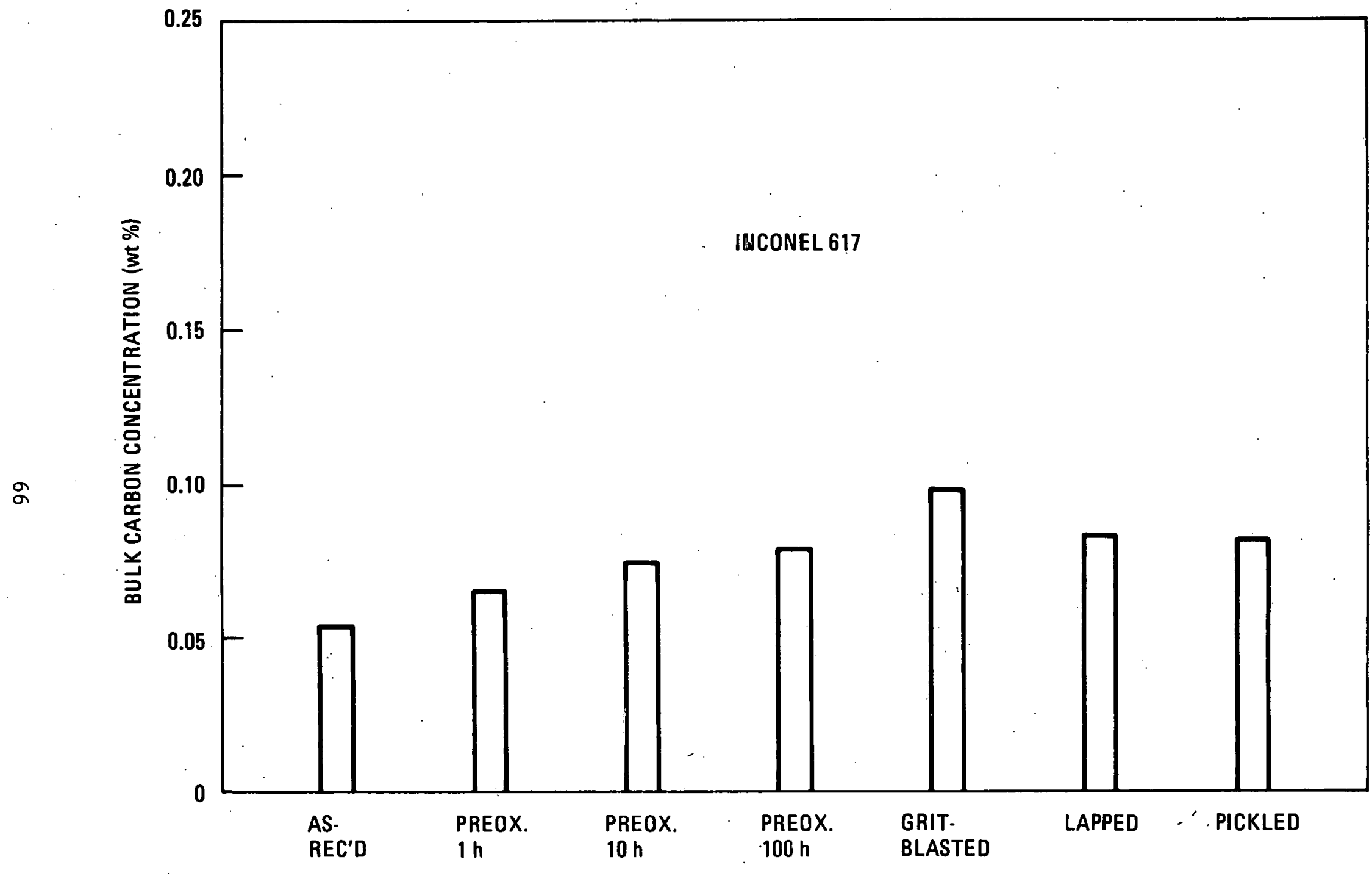

Fig. 47. Bulk carbon concentrations for Inconel 617 specimens following exposure for $3000 \mathrm{~h}$ at $900^{\circ} \mathrm{C}$ to controlled-impurity helium containing $500 \mu \mathrm{atm} \mathrm{H}_{2} / 50 \mu \mathrm{atm} \mathrm{CO} / 50 \mu \mathrm{atm} \mathrm{CH}_{4} /<0.5$ Hatm $\mathrm{H}_{2} \mathrm{O}$ 


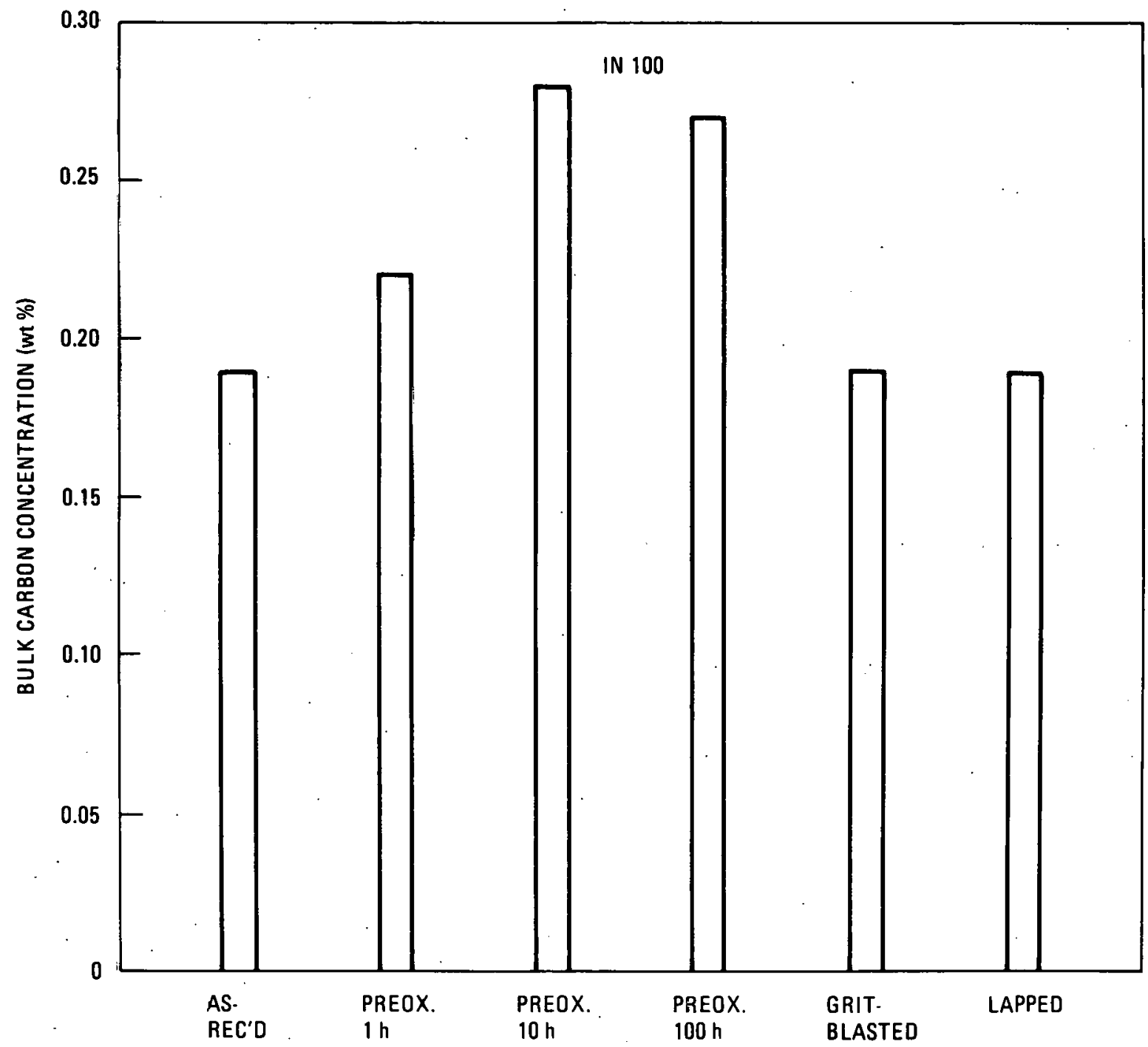

Fig. 48. Bulk carbon concentrations for IN 100 specimens following exposure for $3000 \mathrm{~h}$ at $900^{\circ} \mathrm{C}$ to controlled-impurity helium containing $500 \mu \mathrm{atm} \mathrm{H}_{2} / 50$ uatm $\mathrm{CO} / 50 \mu$ atm $\mathrm{CH}_{4} /<0 . \dot{5}$ Hatm $\mathrm{H}_{2} \mathrm{O}$ 


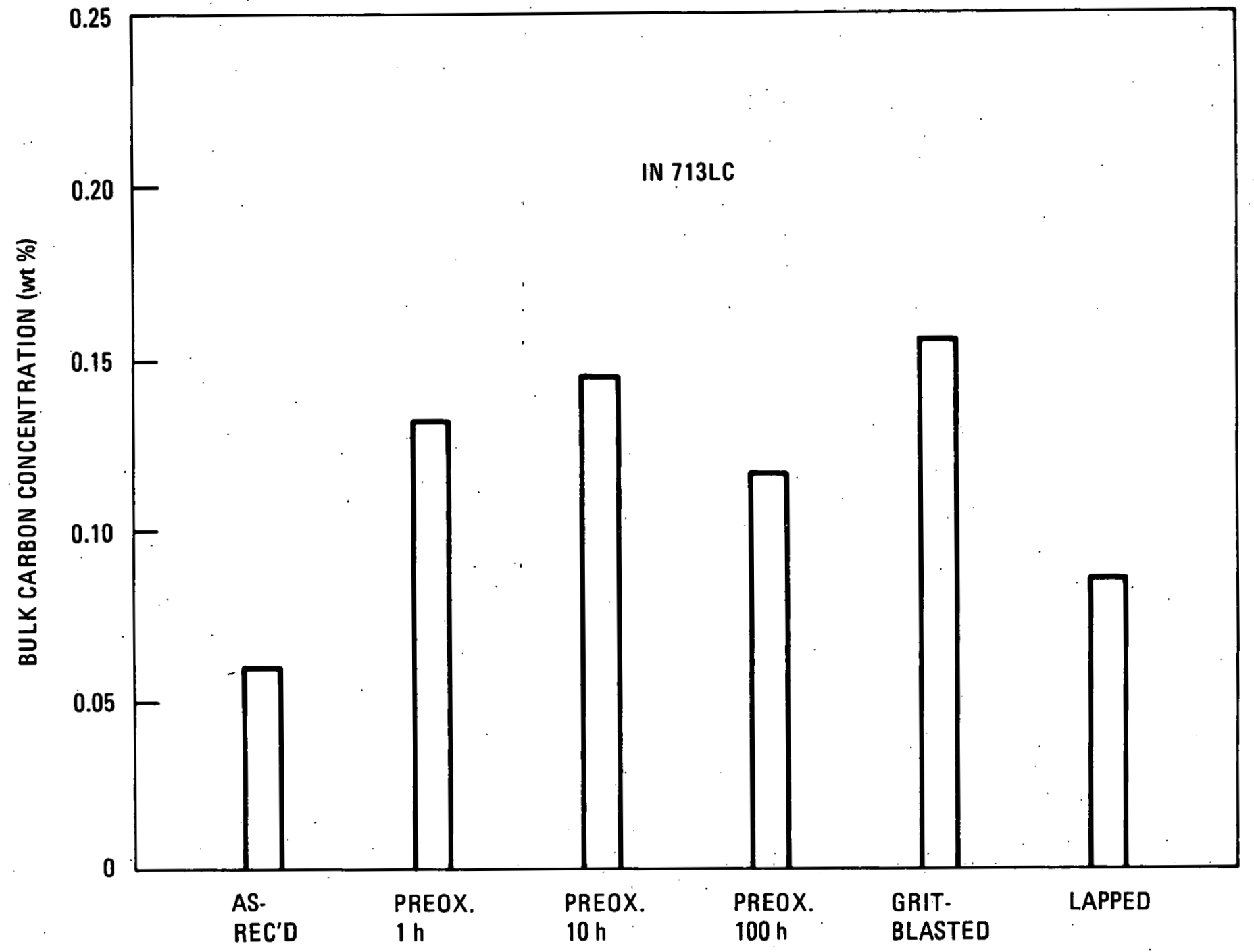

Fig. 49. Bulk carbon concentrations for IN 713L.C specimens following exposure for $3000 \mathrm{~h}$ at $900^{\circ} \mathrm{C}$ to controlled-impurity helium containing $500 \mu \mathrm{atm} \mathrm{H}_{2} / 50 \mu \mathrm{atm} . \mathrm{Co} / 50 \mu \mathrm{atm} \mathrm{CH}_{4} /<0.5$ Hatm $\mathrm{H}_{2} \mathrm{O}$ 


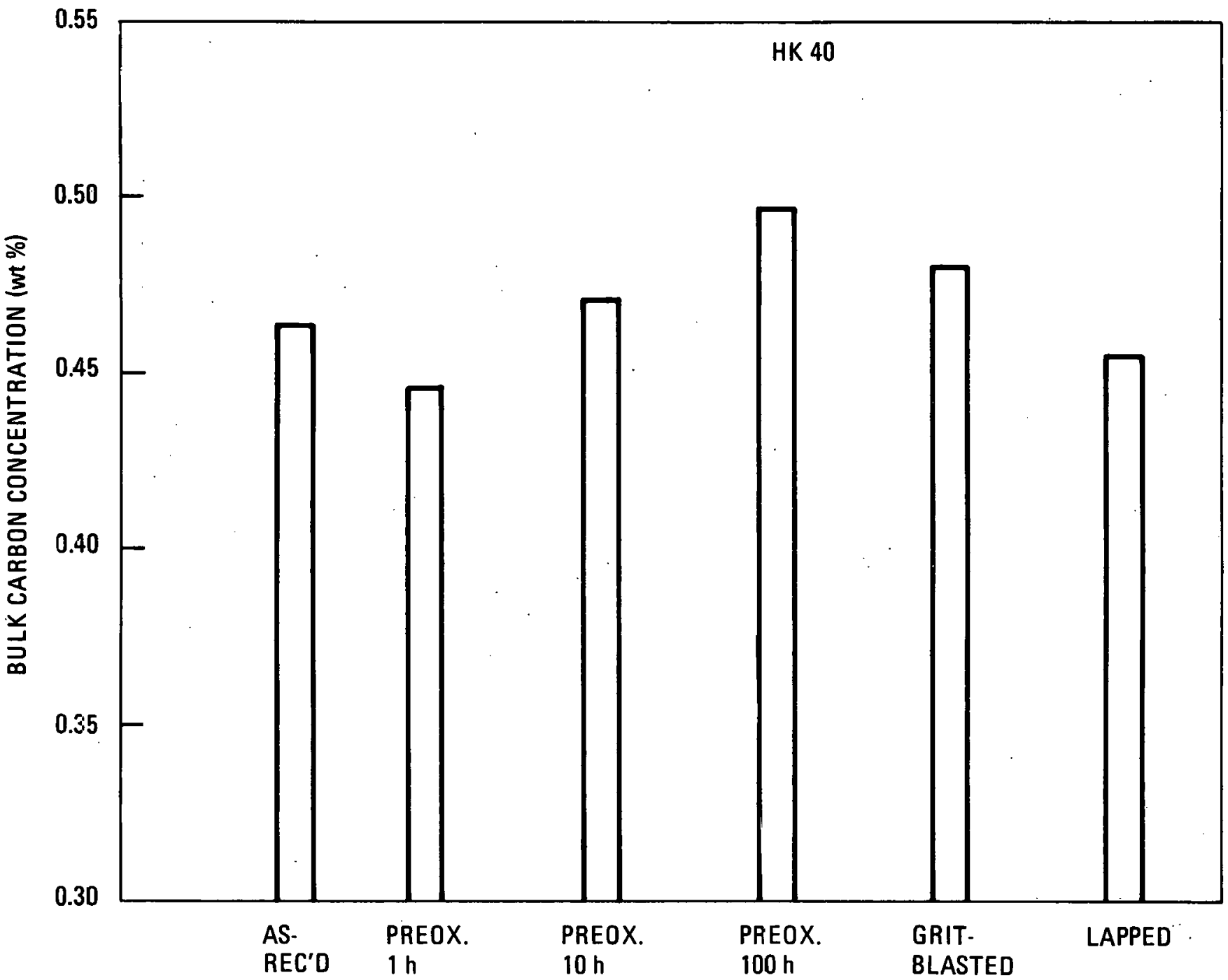

Fig. 50. Bulk carbon concentrations for HK 40 specimens following exposure for $3000 \mathrm{~h}$ at $900^{\circ} \mathrm{C}$ to controlled-impurity helium containing $500 \mu \mathrm{atm} \mathrm{H}_{2} / 50 \mu \mathrm{atm} \mathrm{CO} / 50 \mu \mathrm{atm} \mathrm{CH}_{4} /<0.5$ Hatm $\mathrm{H}_{2} \mathrm{O}$ 


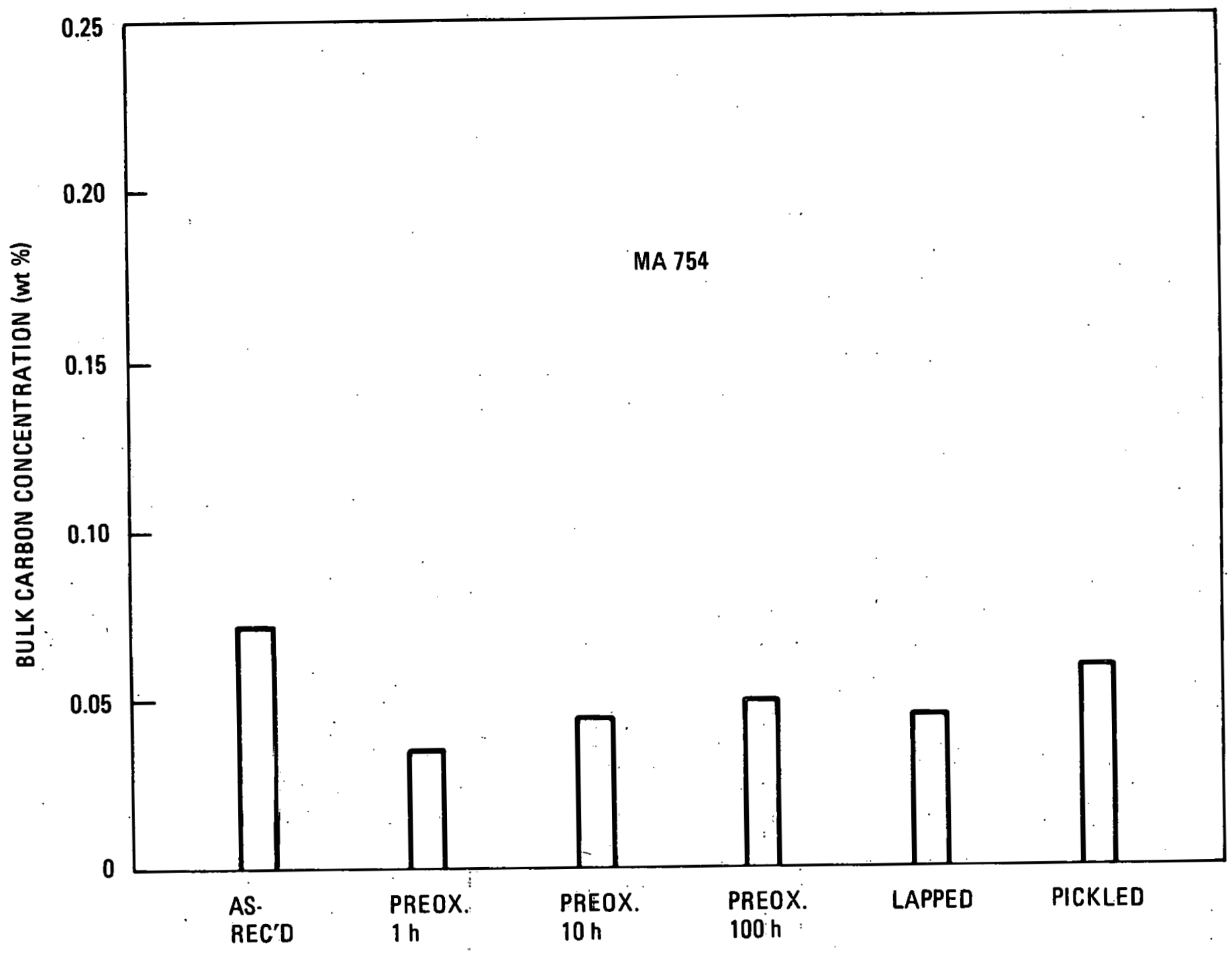

Fig. 51. Bulk carbon concentrations for MA 754 specimens. following exposure for $3000 \mathrm{~h}$ at $900^{\circ} \mathrm{C}$ to controlled-impurity helium containing $500 \mu \mathrm{atm} \mathrm{H}_{2} / 50 \mu \mathrm{atm} \mathrm{CO} / 50 \mu \mathrm{atm} \mathrm{CH}_{4} /<0.5 \mu \mathrm{atm} \mathrm{H}_{2} \mathrm{O}$ 
It is clear from Figs. 45 through 47 that preoxidation treatments were effective in controlling carburization for Alloy $800 \mathrm{H}$ and Hastelloy $X$ and partially effective in the case of Inconel 617. For the latter alloy, longer-term preoxidation treatments were less effective than the short-term 1-h treatment. No consistent observations along these lines could be made for the other wrought alloys, which exhibited only modest increases in carbon concentrations (if any) for all preoxidized specimens. Aside from preoxidation, the other surface treatments had little effect on the subsequent carburization of the wrought high-temperature alloys in controlled-impurity helium.

Figure 48 shows the carbon concentrations measured for IN 100 . In sharp contrast to the wrought alloys, carburization was more pronounced in specimens given prior preoxidation treatments. The lapped and gritblasted specimens showed virtually no change in carbon content following the controlled-impurity helium exposure. The resistance of IN 100 to carburization in simulated reactor helium environments has been noted in previous studies (Refs. 1-5).

In Fig. 49, the results indicate that surface finish has little effect on the carburization behavior of IN 713LC. As with IN 100, preoxidation treatments did not inhibit carburization. It has been previously reported that IN $713 \mathrm{LC}$ is not as effective as IN 100 in resisting carburization (Refs. 4, 5); Figs. 48 and 49 would appear to confirm the earlier observations.

Figure 50 shows the bulk carbon data for HK 40. The driving force for carburization (relative to the initial carbon concentration) to occur is drastically reduced by the large initial carbon concentration of HK 40 . These data would indicate that surface finish plays only a minor role, of secondary importance, in the susceptibility of this alloy to carburization in controlled-impurity helium environments.

The unique situation of MA 754 is clearly shown in Fig. 51. In contrast to the other alloys tested, the phenomenon of decarburization 
occurred upon exposure to a simulated reactor helium environment. Decarburization of MA 754 has been associated with the yttria dispersoids and the possibility that the yttria/matrix interface acts as a favorable surface for the oxidation of matrix carbon (Ref. 5). Again, these experiments did not indicate that surface finish had an important effect on the corrosion behavior of MA 754 . 


\section{DISCUSSION}

The effects of surface finish on the controlled-impurity helium corrosion behavior of seven candidate alloys are summarized in Table 3 . The important surface corrosion product morphological characteristics observed for the vartous surface conditions studied are also given in Table 3. The behavior of three alloys, MA 754, HK 40, and IN 713LC, was essentially independent of the initial surface finish. Carburization of alloys $\mathrm{HK} 40$ and IN 713LC was not inhibited by any particular surface condition including preoxidation. The decarburization behavior of MA 754 was also not strongly affected by altering surface condition.

IN 100 and the wrought high-temperature alloys, Alloy 800H, Hastelloy $X$, and Inconel 617, showed a stronger effect of surface condition on simulated reactor environment performance. Preoxidation treatments were ineffective in controlling the carburization of IN 100 and actually increased carburization susceptibility. Most probably this was related to the oxide that formed in the preoxidation exposure. IN 100 has been shown to be resistant to carburization in previous simulated reactor heliuin cursustun studies (Refs. 1-5) and this behavior was related to the formation of a thin, continuous, adherent, aluminum-rich oxide scale (Refs. 4,5). Carburization resistance was enhanced when this alumina scale contained small but measureable amounts of titanium.

When exposed to air, the oxidation behavior is likely to be much different, and the evolution of chromium-aluminum-based oxides was observed. Mixed oxides and chromium-based oxides, formed during controlled-impurity helium exposures, have been shown to be generally ineffective in controlling carburization in most alloys (Refs. 1-5). Previous studies have shown that oxidation of IN 100 at $760^{\circ}$ to $1100^{\circ} \mathrm{C}$ in air does not produce 
TABLE 3

CORROSION BEHAVIOR AFTER 3000-HOUR EXPOSURES TO A CONTROLLED-IMPURITY HELIUM ENVIRONMENT

\begin{tabular}{|c|c|c|c|c|c|}
\hline Alloy & Surface Condition & $\begin{array}{c}\text { Surface Scale } \\
\text { Thickness } \\
(\mu \mathrm{m})\end{array}$ & $\begin{array}{c}\text { Depth of Internal } \\
\text { Oxidation } \\
(\mu \mathrm{m})\end{array}$ & $\begin{array}{c}\text { Depth of Alloying Element } \\
\text { Depleted Zone } \\
(\mu \mathrm{m})\end{array}$ & \begin{tabular}{|c} 
Carburized \\
$\begin{array}{l}\text { Zone Perietration } \\
\text { Depth } \\
(\mu \mathrm{m})\end{array}$ \\
\end{tabular} \\
\hline Alloy $800 \mathrm{H}$ & $\begin{array}{l}\text { Preoxidized } 1 \mathrm{~h} \\
\text { Preoxidized } 10 \mathrm{~h} \\
\text { Preoxidized } 100 \mathrm{~h} \\
\text { Grit-blasted } \\
\text { Lapped } \\
\text { Pickled } \\
\end{array}$ & $\begin{array}{l}13 \\
14 \\
13 \\
10 \\
10 \\
11 \\
\end{array}$ & $\begin{array}{r}41 \\
44 \\
44 \\
76 \\
29 \\
32 \\
\end{array}$ & $\begin{array}{l}70 \\
89 \\
89 \\
76 \\
51 \\
38\end{array}$ & $\begin{array}{r}-- \\
-- \\
680 \\
735 \\
815 \\
\end{array}$ \\
\hline Hastelloy $\mathrm{X}$ & $\begin{array}{l}\text { Preoxidized } 1 \mathrm{~h} \\
\text { Preoxidized } 10 \mathrm{~h} \\
\text { Preoxidized } 100 \cdot \mathrm{h} \\
\text { Grit-blasted } \\
\text { Lapped } \\
\text { Pickled } \\
\end{array}$ & $\begin{array}{r}10 \\
8 \\
8 \\
8 \\
8 \\
11 \\
11\end{array}$ & $\begin{array}{l}29 \\
25 \\
25 \\
25 \\
25 \\
25\end{array}$ & $\begin{array}{l}29 \\
25 \\
25 \\
51 \\
51 \\
51\end{array}$ & $\begin{array}{r}-- \\
-- \\
-- \\
222 \\
222 \\
191\end{array}$ \\
\hline Inconel 617 & $\begin{array}{l}\text { Preoxidized } 1 \mathrm{~h} \\
\text { Preoxidized } 10 \mathrm{~h} \\
\text { Preoxidized } 100 \mathrm{~h} \\
\text { Grit-blasted } \\
\text { Lapped } \\
\text { Pickled } \\
\end{array}$ & $\begin{array}{l}8 \\
8 \\
8 \\
8 \\
6 \\
8 \\
\end{array}$ & $\begin{array}{l}32 \\
32 \\
38 \\
38 \\
25 \\
44 \\
\end{array}$ & $\begin{array}{l}70 \\
70 \\
70 \\
64 \\
51 \\
67 \\
\end{array}$ & $\begin{array}{l}308 \\
381 \\
254 \\
572 \\
381 \\
635 \\
\end{array}$ \\
\hline IN 100 & $\begin{array}{l}\text { Preoxidized } 1 \mathrm{~h} \\
\text { Preoxidized } 10 \mathrm{~h} \\
\text { Preoxidized } 100 \mathrm{~h} \\
\text { Grit-blasted } \\
\text { Lapped }\end{array}$ & $\begin{array}{r}4 \\
13 \\
60 \\
6 \\
10 \\
\end{array}$ & $\begin{array}{r}32 \\
41 \\
70 \\
6 \\
10\end{array}$ & $\begin{array}{r}44 \\
70 \\
108 \\
38 \\
38 \\
\end{array}$ & $\begin{array}{r}-- \\
191 \\
445 \\
76 \\
89\end{array}$ \\
\hline IN $713 \mathrm{LC}$ & $\begin{array}{l}\text { Preoxidized } 1 \mathrm{~h}, \\
\text { Preoxidized } 10 \mathrm{~h} \\
\text { Preoxidized } 100 \mathrm{~h} \\
\text { Grit-blasted } \\
\text { Lapped }\end{array}$ & $\begin{array}{r}4 \\
6 \\
10 \\
6 \\
10 \\
10\end{array}$ & $\begin{array}{l}41 \\
51 \\
38 \\
32 \\
38\end{array}$ & $\begin{array}{l}57 \\
70 \\
64 \\
51 \\
57\end{array}$ & $\begin{array}{l}572 \\
572 \\
572 \\
318 \\
635 \\
\end{array}$ \\
\hline $\mathrm{HK} 40$ & $\begin{array}{l}\text { Preoxidized } 1 \mathrm{~h} \\
\text { Preoxidized } 10 \mathrm{~h} \\
\text { Preoxidized } 100 \mathrm{~h} \\
\text { Grit-blasted } \\
\text { Lapped }\end{array}$ & $\begin{array}{r}10 \\
11 \\
10 \\
11 \\
8 \\
\end{array}$ & $\begin{array}{l}19 \\
29 \\
25 \\
29 \\
22 \\
\end{array}$ & $\begin{array}{l}25 \\
32 \\
25 \\
32 \\
22 \\
\end{array}$ & $\begin{array}{l}403 \\
410 \\
590 \\
508 \\
572 \\
\end{array}$ \\
\hline MA 754 & $\begin{array}{l}\text { Preoxidized } 1 \mathrm{~h} \\
\text { Preoxidized } 10 \mathrm{~h} \\
\text { Preoxidized } 100 \mathrm{~h} \\
\text { Lapped } \\
\text { Pickled }\end{array}$ & $\begin{array}{l}4 \\
3 \\
3 \\
4 \\
4\end{array}$ & $\begin{array}{l}-- \\
-- \\
-- \\
--\end{array}$ & $\begin{array}{l}-- \\
-- \\
-- \\
--\end{array}$ & $\begin{array}{l}-- \\
-- \\
--\end{array}$ \\
\hline
\end{tabular}


$\mathrm{Al}_{2} \mathrm{O}_{3}$ as the steady-state scale (Ref. 19). The establishment of a (Ni,Co)O surface oxide layer containing large proportions of $\mathrm{TiO}_{2}$ as an initial scale is caused by surface chemical inhomogeneities. The low, but still adequate, oxygen potential beneath this scale causes aluminum to be internally oxidized, as was observed in Fig. 35. Rapid oxidation continues and the surface scale that eventually evolves [(Ni,Co)o containing $\mathrm{NiTiO}_{3}$ ] has a defect structure such that carbon ingress can continue unabated while a scale more stable in HTGR helium forms. In the cases of the grit-blasted and lapped IN 100 specimens, alumina scales containing titanium, which naturally formed during the controlled-impurity helium exposure, significantly inhibited carburization. This behavior contrasts well with that of IN 713LC, where alumina scales could still form (except in the preoxidized specimens), but the low titanium concentration of IN 713LC limited the ability to incorporate titanium into the alumina scale; the scale thus formed was not as effective as a carburization barrier. These observations are consistent with previous studies that outlined the importance of aluminum-based oxides in carburization control (Refs. 4, 5).

The effectiveness of preoxidized surface scales in inhibiting the carburization of the wrought high-temperature alloys revealed many important features of the corrosion behavior of wrought alloys in simulated reactor helium. The formation of preoxidized surface scales virtually eliminated carburization for the two wrought alloys, Alloy $800 \mathrm{H}$ and Hastelloy $\mathrm{X}$, while decreasing the severity of carburization for Incone1 617 .

Attention was focused on the scale characteristics pertaining to Alloy $800 \mathrm{H}$ and Hastelloy $\mathrm{X}$. Figures 52 through 54 show the surface scales of preoxidized Alloy $800 \mathrm{H}$ in the preoxidized condition and following the controlled-impurity helium exposures. As preoxidation time increased, the thickness of the oxide scale formed during preoxidation increased, as would be expected. The same can be slated for the prooxidation behavior of Hastelloy $\mathrm{X}$, shown in Figs. 55 through 57 . Interestingly envugh, the thickncsscs of the surface nxide scales following the 

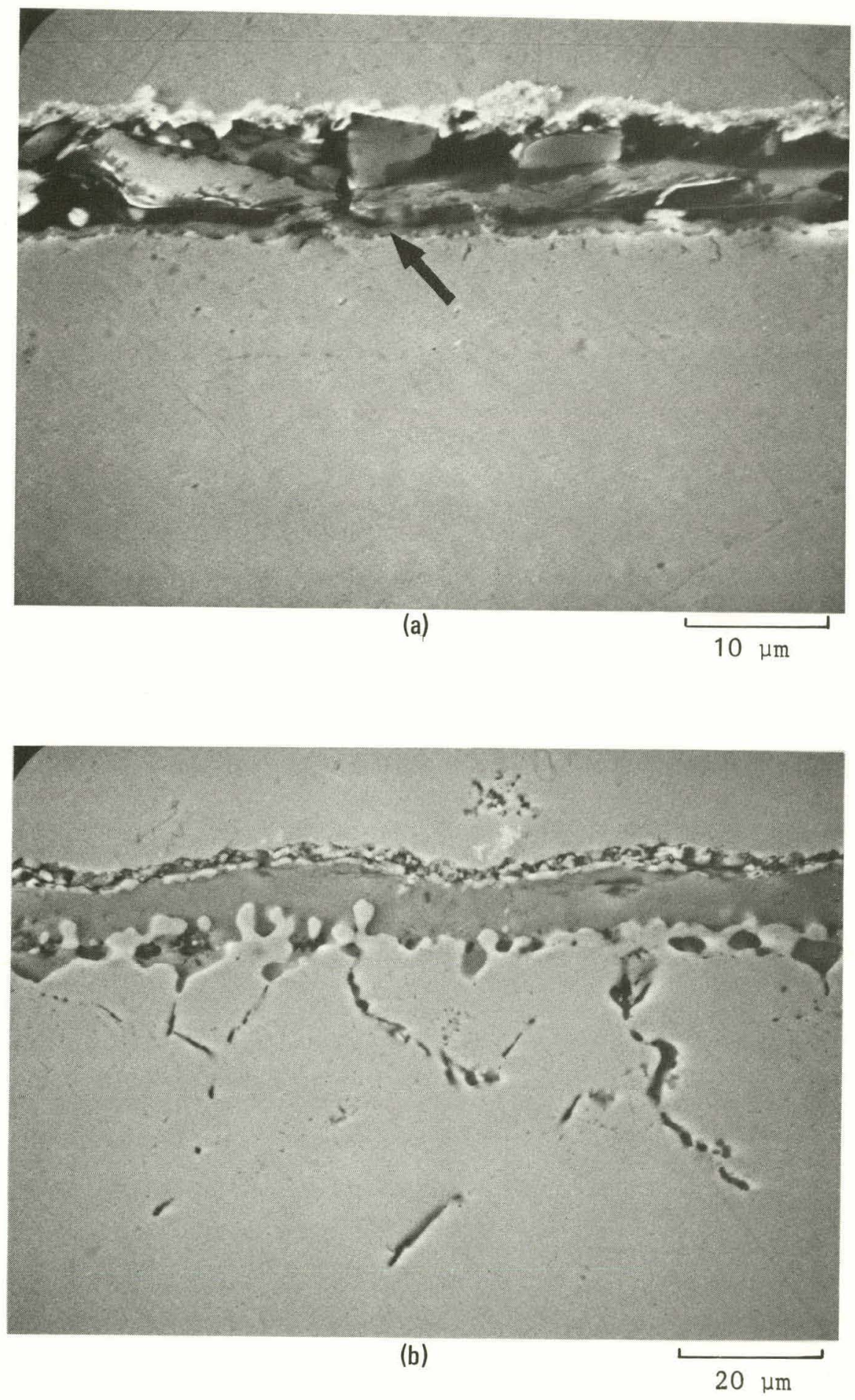

Fig. 52. Scanning electron micrographs showing surface scales formed on Alloy $800 \mathrm{H}$ : (a) preoxidized at $900^{\circ} \mathrm{C}$ in air for $1 \mathrm{~h}$ and (b) preoxidized in air for $1 \mathrm{~h}$ and exposed for $3000 \mathrm{~h}$ in He/500 $\mu \mathrm{atm}$ $\mathrm{H}_{2} / 50$ matm $\mathrm{CO} / 50$ atm $\mathrm{CH}_{4} /<0.5 \mu \mathrm{atm} \mathrm{H}_{2} \mathrm{O}$ at $900^{\circ} \mathrm{C}$. Arrow in (a) indicates oxide scale. 


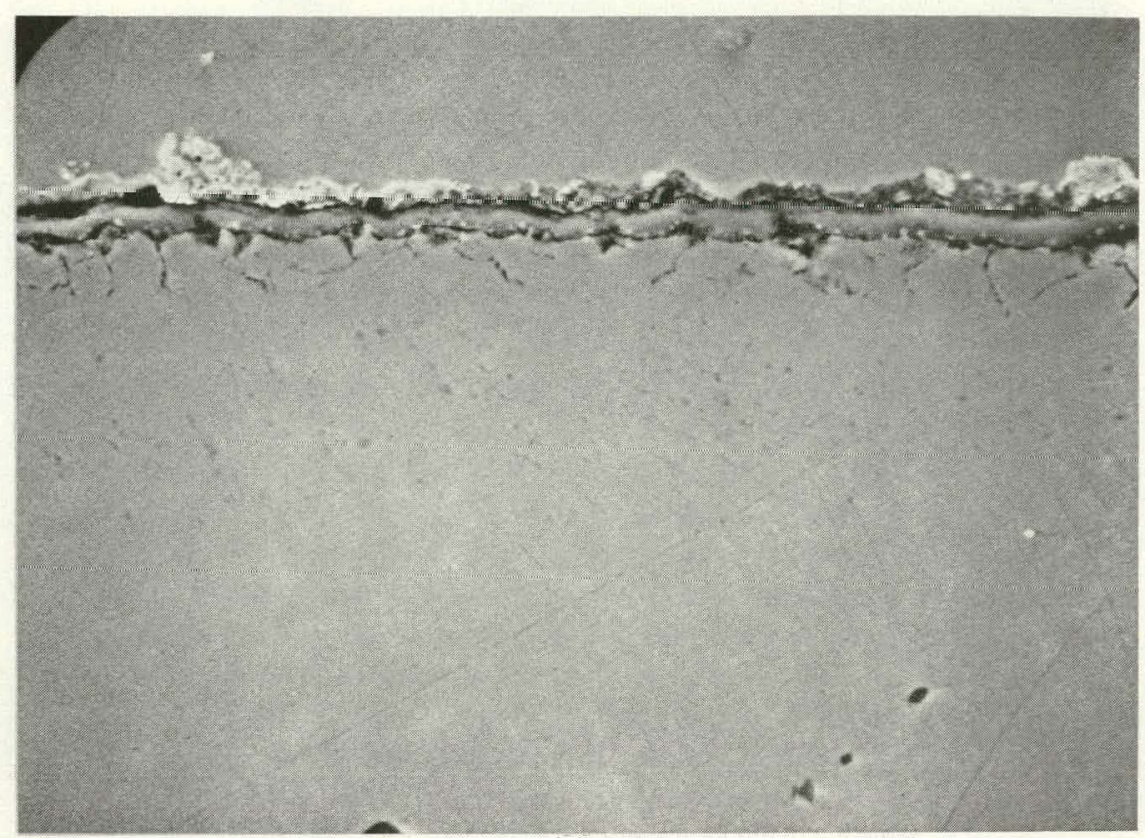

(a)

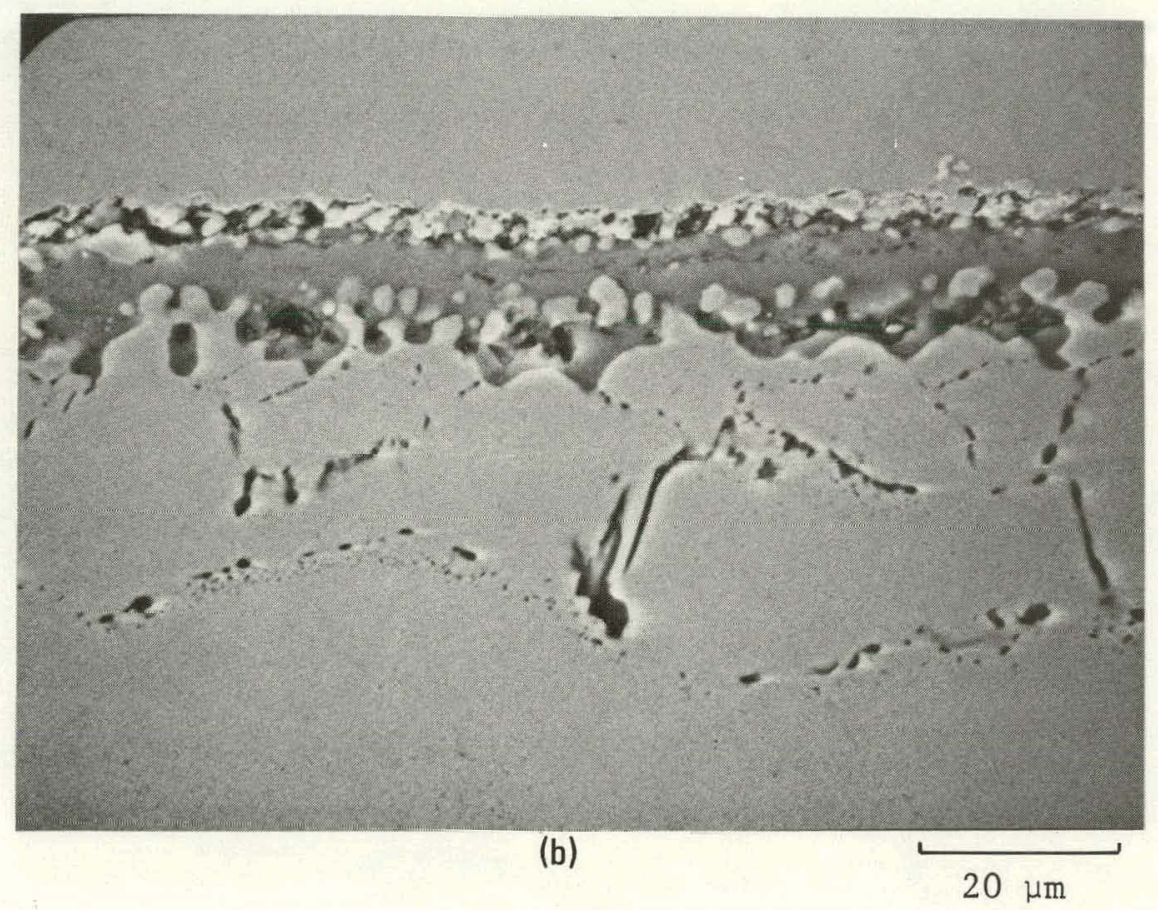

Fig. 53. Scanning electron micrographs showing surface scales formed on Alloy $800 \mathrm{H}$ : (a) preoxidized at $900^{\circ} \mathrm{C}$ in air for $10 \mathrm{~h}$ and (b) preoxidized in air for $10 \mathrm{~h}$ and exposed for $3000 \mathrm{~h}$ in $\mathrm{He} / 500$

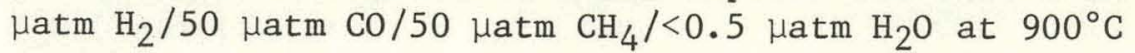




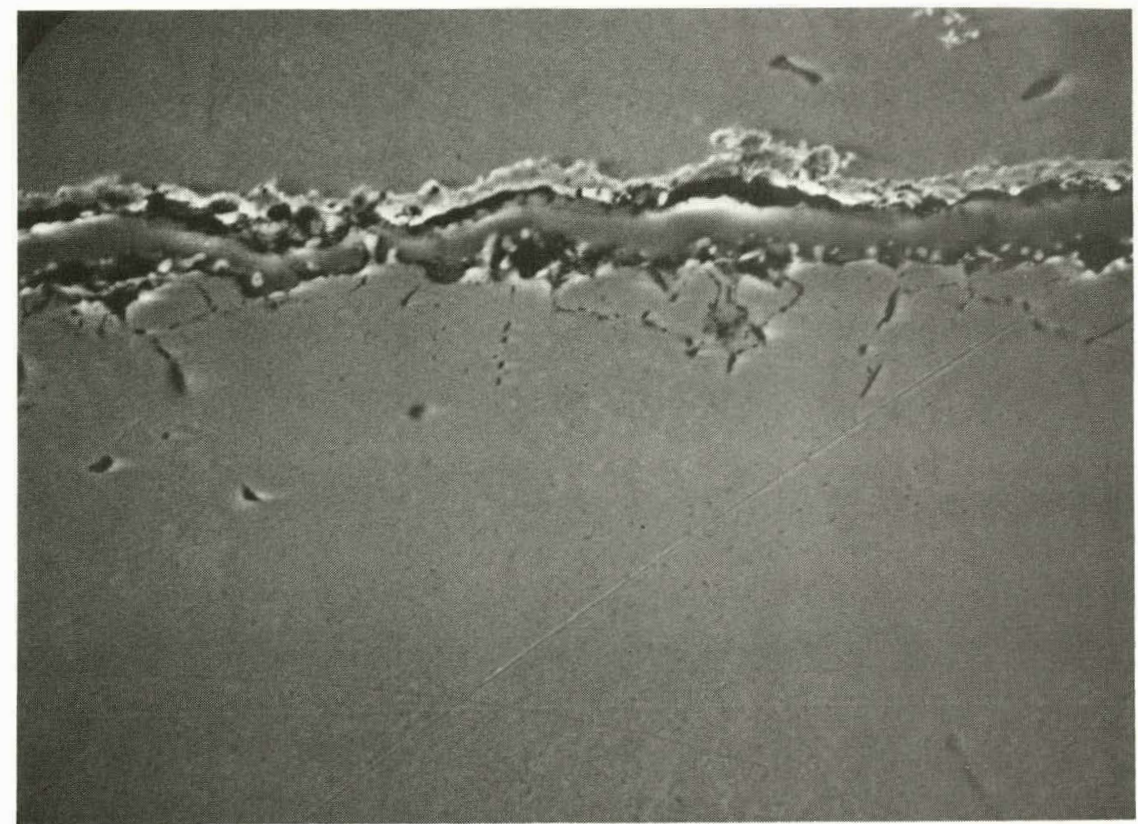

(a)

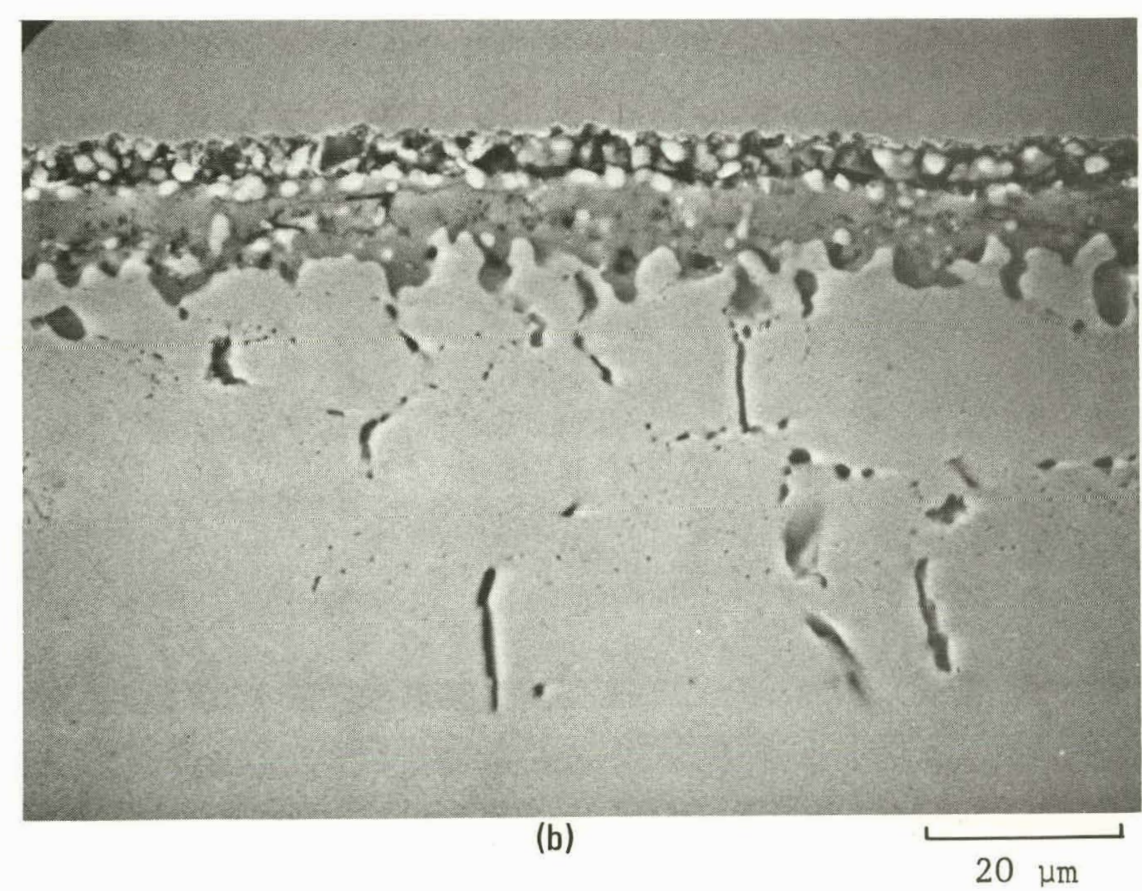

Fig. 54. Scanning electron micrographs showing surface scales formed on Alloy 800H: (a) preoxidized at $900^{\circ} \mathrm{C}$ in air for $100 \mathrm{~h}$ and (b) preoxidized in air for $100 \mathrm{~h}$ and exposed for $3000 \mathrm{~h}$ in He/500

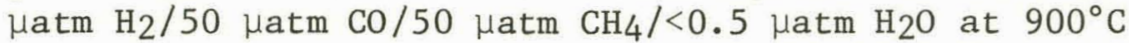




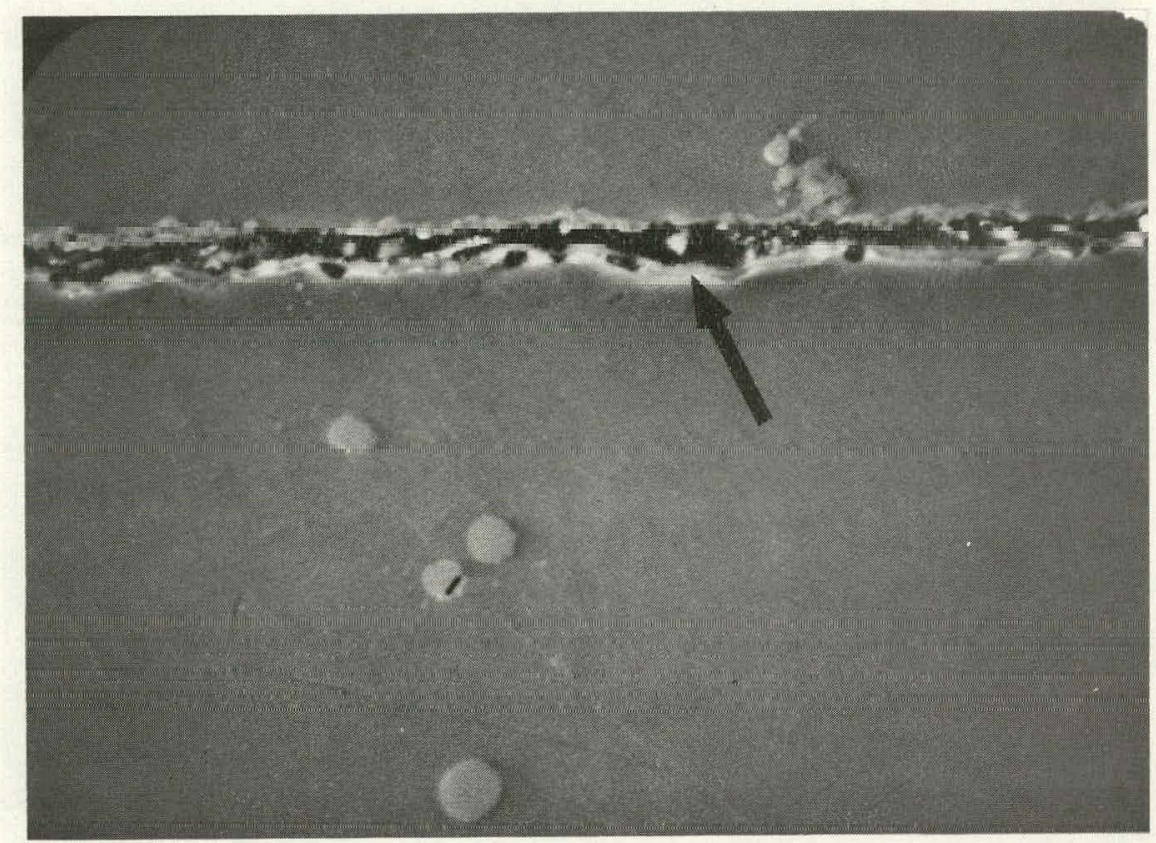

(a)

$10 \mu \mathrm{m}$

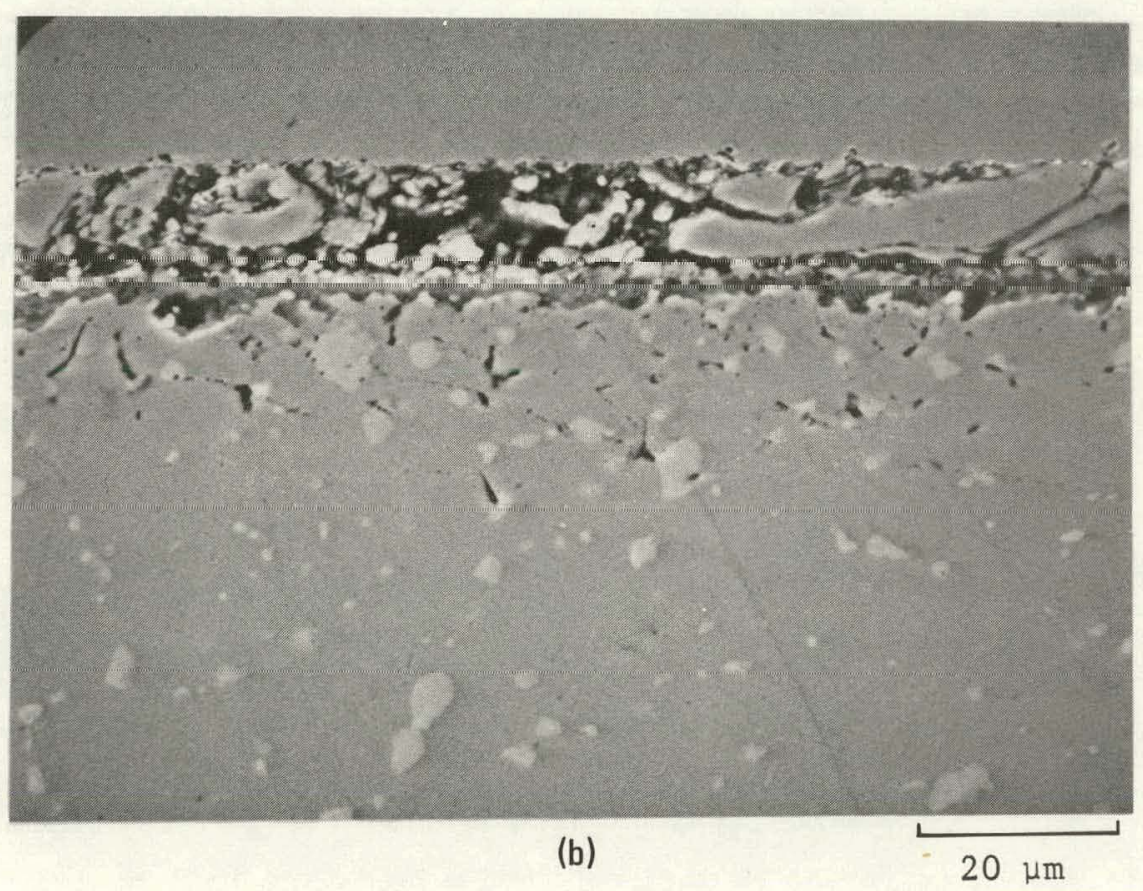

Fig. 55. Scanning electron micrographs showing surface scales formed on Hastelloy $\mathrm{X}$ : (a) preoxidized at $900^{\circ} \mathrm{C}$ in air for $1 \mathrm{~h}$ and (b) preoxidized in air for $1 \mathrm{~h}$ and exposed for $3000 \mathrm{~h}$ in He/500 Hatm $\mathrm{H}_{2} / 50$ matm $\mathrm{CO} / 50$ matm $\mathrm{CH}_{4} /<0.5 \mu \mathrm{atm} \mathrm{H}_{2} \mathrm{O}$ at $900^{\circ} \mathrm{C}$. Arrow in (a) indicates oxide scale. 


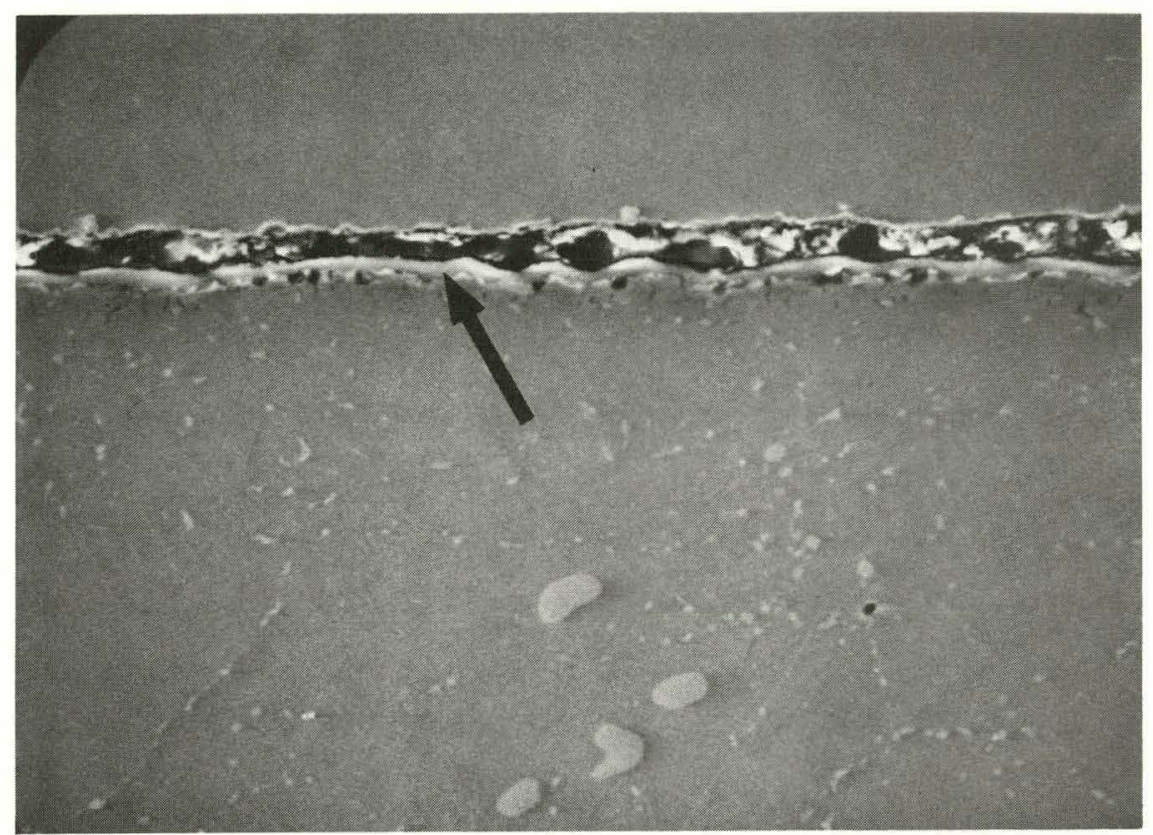

(a)

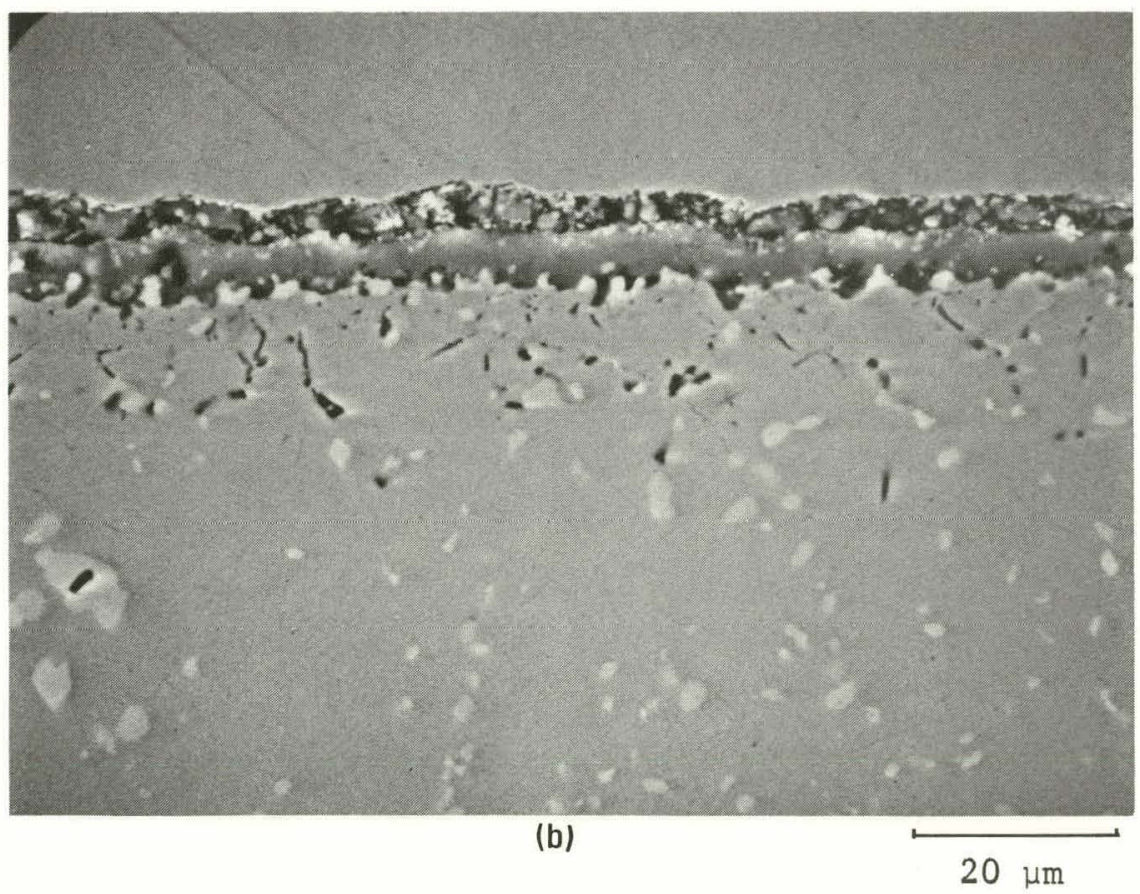

Fig. 56. Scanning electron micrographs showing surface scales formed on Hastelloy X: (a) preoxidized at $900^{\circ} \mathrm{C}$ in air for $10 \mathrm{~h}$ and (b) preoxidized in air for $10 \mathrm{~h}$ and exposed for $3000 \mathrm{~h}$ in $\mathrm{He} / 500$

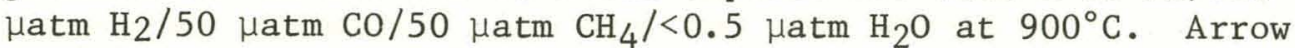
in (a) indicates oxide scale. 


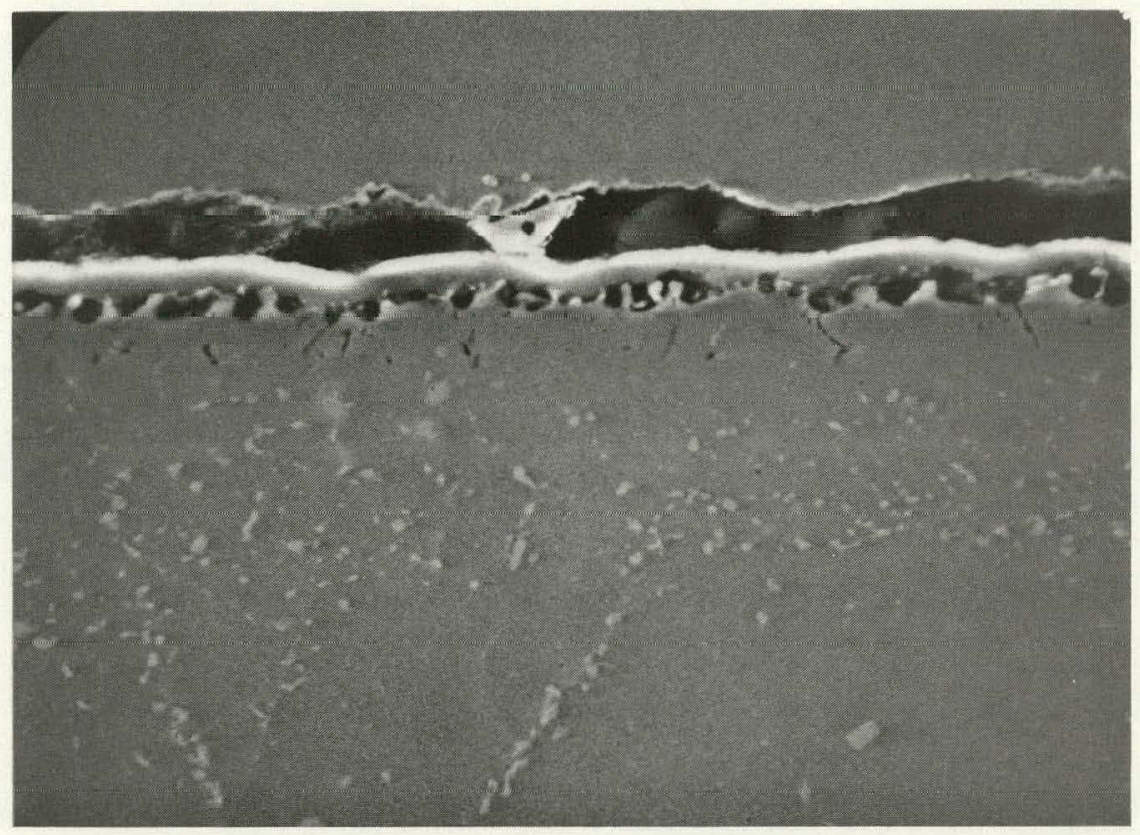

(a)

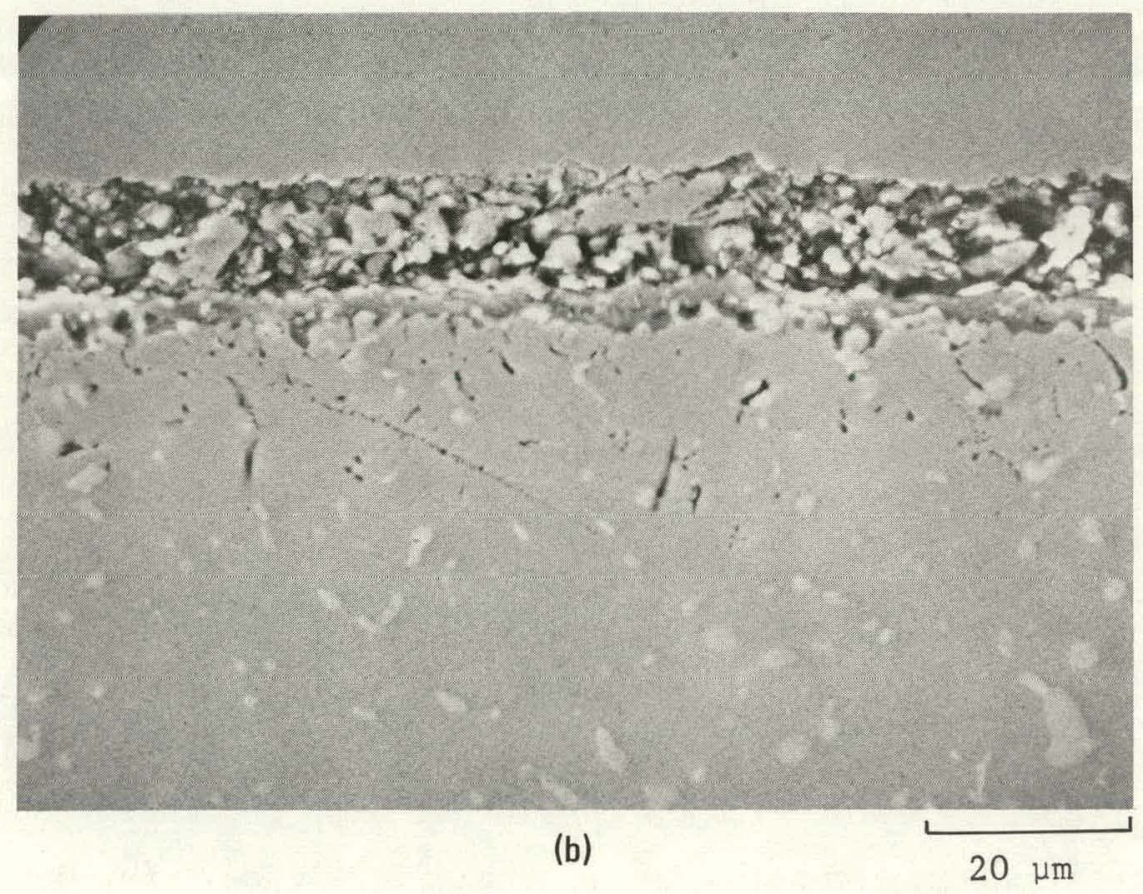

Fig. 57. Scanning electron micrographs showing surface scales formed on Hastelloy X: (a) preoxidized at $900^{\circ} \mathrm{C}$ in air for $100 \mathrm{~h}$ and (b) preoxidized in air for $100 \mathrm{~h}$ and exposed for $3000 \mathrm{~h}$ in

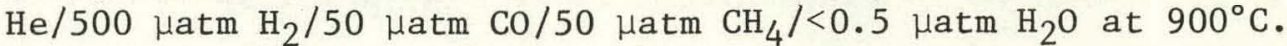


controlled-impurity helium exposures were a function of alloy chemistry but were independent of initial preoxidized scale thickness. (It should be noted that whitish areas on the outer edge of the surface scales are silver nodules. Silver was deposited on the specimens prior to the electrodeposition of nickel to promote adhesion of the nickel. This procedure was followed to maintain good edge retention of the specimens. Despite these efforts, examples where the oxide has separated from the protective nickel layer were observed. In Fig. 51a, for example, diamond paste polishing compound particles have become embedded in between the oxide and the mounting resin.)

Table 4 shows the concentrations of metallic elements found in the oxide surface layers, in both the preoxidized and the post-HTGR-GT exposure conditions for Alloy $800 \mathrm{H}$ and Hastelloy X. After 1-h preoxidation treatments, the scales for both alloys were chromium-rich but contained substantial proportions of other metallic elements. These scales were very thin and therefore difficult to analyze without matrix "shine" and interference. Although initial stages of oxide formation in these alloys are complex and involve the formation of oxide phases of intermediate stability (Ref. 18), the longer-term preoxidation treatments led to the formation of $\mathrm{Cr}_{2} \mathrm{O}_{3}$ scales for both alloys with only trace quantities of other metallic elements.

Following the controlled-impurity helium exposure, the protective oxide scales were found to contain substantial proportions of manganese. In the case of Alloy $800 \mathrm{H}$, manganese concentrations on the order of onethird to one-half the concentrations of chromium were observed. The composition of the scales on Alloy $800 \mathrm{H}$ was uniform, indicating that a metastable steady-state situation had probably developed. For Hastelloy $\mathrm{x}$, only the scale of the 1-h preoxidized specimen had manganese concentrations in proportion to those observed for Alloy $800 \mathrm{H}$. Those Hastelloy $\mathrm{X}$ specimens that had been given 10 or $100 \mathrm{~h}$ preoxidation treatments had lower manganese concentrations in the oxide scales. Some Japanese studies (Refs. 20, 21) have shown manganese to be beneficial in inhibiting 
TABLE 4

CONCENTRATIONS OF ME:ALLIC ELEMENTS OBSERVED IN OXIDE SURFACE SCALES FORMED ON HASTELLOY X AND ALLOY 800H FOR PREOXIDIZED AND HTGR-GT EXPOSURE CONDITIONS

\begin{tabular}{|c|c|c|}
\hline Alloy & Condition & $\begin{array}{c}\text { Concentration of Metallic Elements in } \\
\text { Surface Oxide Scale } \\
\text { (wt \%) }\end{array}$ \\
\hline Alloy $800 \mathrm{H}$ & $\begin{array}{l}\text { Preoxidized in air for } 1 \mathrm{~h} \text { at } 900^{\circ} \mathrm{C} \\
\text { Preoxidized in air for } 10 \mathrm{~h} \text { at } 900^{\circ} \mathrm{C} \\
\text { Preosidized in air for } 100 \mathrm{~h} \text { at } 900^{\circ} \mathrm{C} \\
\text { Preozidized } 1 \mathrm{~h}+3000 \mathrm{~h} \text { in controlled- } \\
\text { impurity He } \\
\text { Preozidized } 10 \mathrm{~h}+3000 \mathrm{i} \text { in controlled- } \\
\text { impuzity He } \\
\text { Preoxidized } 100 \mathrm{~h}+3000 \mathrm{~h} \text { in controlled- } \\
\text { impuzity He }\end{array}$ & $\begin{array}{l}68 \mathrm{Cr}, 11 \mathrm{Ni}, 10 \mathrm{Fe}, 4.3 \mathrm{Mn}, 3.6 \mathrm{Al}, 1.6 \mathrm{Ti}, 0.6 \mathrm{Si} \\
98 \mathrm{Cr}, 1 \mathrm{Ti}, 0.7 \mathrm{Mn}, 0.3 \mathrm{Si} \\
98 \mathrm{Cr}, 0.8 \mathrm{Ti}, 0.8 \mathrm{Mn}, 0.1 \mathrm{Fe} \\
67 \mathrm{Cr}, 28 \mathrm{Mn}, 2.5 \mathrm{Ti}, 0.7 \mathrm{Al}, 0.6 \mathrm{Si}, 0.6 \mathrm{Ni} \\
70 \mathrm{Cr}, 25 \mathrm{Mn}, 3 \mathrm{Ti}, 1 \mathrm{Al}, 1 \mathrm{Si}, 0.3 \mathrm{Fe} \\
68 \mathrm{Cr}, 28 \mathrm{Mn}, 2.8 \mathrm{Ti}, 0.5 \mathrm{Fe}, 0.2 \mathrm{Al}\end{array}$ \\
\hline Hastelloy $\mathrm{X}$ & $\begin{array}{l}\text { Preoxidized in air for } 1 \mathrm{~h} \text { at } 900^{\circ} \mathrm{C} \\
\text { Preoxidized in air for } 10 \mathrm{~h} \text { at } 900^{\circ} \mathrm{C} \\
\text { Preoxidized in air for } 100 \mathrm{~h} \text { at } 900^{\circ} \mathrm{C} \\
\text { Preoxidized } 1 \mathrm{~h}+3000 \mathrm{~h} \text { in controlled- } \\
\text { impurity He } \\
\text { Preoxidized } 10 \mathrm{~h}+3000 \mathrm{~h} \text { in controlled- } \\
\text { impurity He } \\
\text { Preoxidized } 100 \mathrm{~h}+3000 \mathrm{~h} \text { in controlled- } \\
\text { impurity He }\end{array}$ & $\begin{array}{l}82 \mathrm{Cr}, 6.5 \mathrm{Ni}, 4.7 \mathrm{Mo}, 4 \mathrm{Fe}, 1.4 \mathrm{Si}, 1.2 \mathrm{Mn}, 0.1 \mathrm{Co} \\
97.8 \mathrm{Cr}, 1 \mathrm{Mn}, 0.6 \mathrm{Ni}, 0.3 \mathrm{Si}, 0.1 \mathrm{Mo}, 0.1 \mathrm{Fe} \\
98 \mathrm{Cr}, 0.6 \mathrm{Mo}, 0.5 \mathrm{Fe}, 0.3 \mathrm{Mn}, 0.3 \mathrm{Si}, 0.2 \mathrm{Ni} \\
73 \mathrm{Cr}, 24 \mathrm{Mn}, 1.3 \mathrm{Si}, 0.7 \mathrm{Fe}, 0.6 \mathrm{Ni} \\
85 \mathrm{Cr}, 14 \mathrm{Mn}, 0.5 \mathrm{Si} \\
82 \mathrm{Cr}, 12 \mathrm{Mn}, 3 \mathrm{Mo}, 3 \mathrm{Si}\end{array}$ \\
\hline
\end{tabular}


corrosion and oxide spallation of Hastelloy $\mathrm{X}$ in simulated reactor helium environments by forming a $\mathrm{Cr}_{2} \mathrm{MnO}_{4}$ spinel. $\mathrm{X}$-ray studies of the postexposed surface scales of the preoxidized specimens (Alloy $800 \mathrm{H}$ and Hastelloy $X$ ) showed that the Alloy $800 \mathrm{H}$ surface oxides were ${ }^{2} \mathrm{Cr}_{2} \mathrm{MnO}_{4}$ spinels with a lattice parameter $a_{0} \approx 8.52 \AA$, while the Hastelloy $X$ surface scales were a mixture of a $\mathrm{Cr}_{2} \mathrm{MnO}_{4}$ spinel, with a lattice parameter of $\approx 8.49 \AA$, and $\mathrm{Cr}_{2} \mathrm{O}_{3}$. Obviously, the scales on the surface of the Hastelloy $X$ specimens were still in a state of transition from $\mathrm{Cr}_{2} \mathrm{O}_{3}$ to $\mathrm{Cr}_{2} \mathrm{MnO}_{4}$ $\left(\mathrm{Cr}_{2} \mathrm{O}_{3}+\mathrm{MnO}\right)$, with the $1-\mathrm{h}$ preoxidized specimen being closest to having completed this transition to a steady-state condition. The compositions of the scales on Alloy $800 \mathrm{H}$ and Hastelloy $X$ were shifting to the stoiciometric composition corresponding to $\mathrm{Cr}_{2} \mathrm{MnO}_{4}$.

Figures 58 through 64 show the surface scale characteristics following the controlled-impurity helium exposure as a function of preoxidation time for all of the alloys studied. In general, the surface scales that developed on the preoxidized specimens were similar, regardless of preoxidation exposure time. The exception was IN 100, as shown in Fig. 61. Particularly after a 100-h preoxidation treatment, the internal oxidation and surface scale thicknesses extended deeply into the alloy matrix as oxidation continued during the controlled-impurity helium exposure.

The effectiveness of the preoxidation treatments in controlling the controlled-impurity helium carburization behavior of Alloy $800 \mathrm{H}$ and Hastelloy $X$ was related to the establishment of a diffusion barrier that prevented carbon ingress. The preoxidized surface scales, essentially $\mathrm{Cr}_{2} \mathrm{O}_{3}$, were unstable with respect to the oxygen potential established in the controlled-impurity helium exposure. $\mathrm{Cr}_{2} \mathrm{O}_{3}$ oxides formed in air, however, did serve as carbon diffusion barriers as the steadystate oxide scales were established. In general, chromium oxides, carbides, or chromium-based duplex and triplex scales formed during controlledimpurity helium exposures are not protective and offer little resistance to continued carburization and/or oxidation (Refs. 1-5). It would appear 


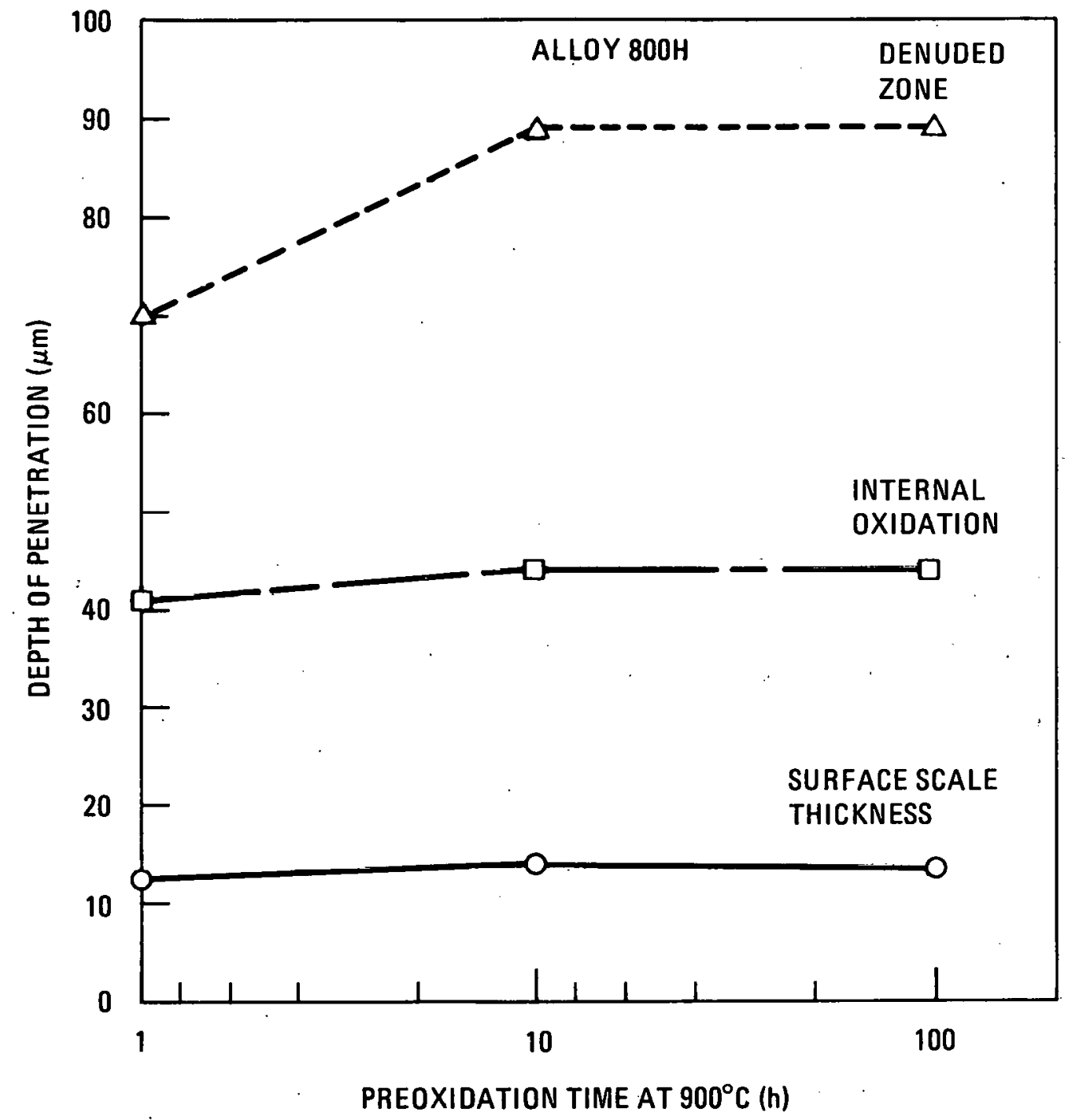

Fig. 58. Corrosion characteristics of preoxidized Alloy $800 \mathrm{H}$ specimens exposed $3000 \mathrm{~h}$ at $900^{\circ} \mathrm{C}$ in controlled-impurity helium containing 500 Hatm $\mathrm{H}_{2} / 50$ Hatm $\mathrm{CO} / 50 \mu \mathrm{atm} \mathrm{CH}_{4} /<0.5 \mu \mathrm{atm} \mathrm{H}_{2} \mathrm{O}$ 


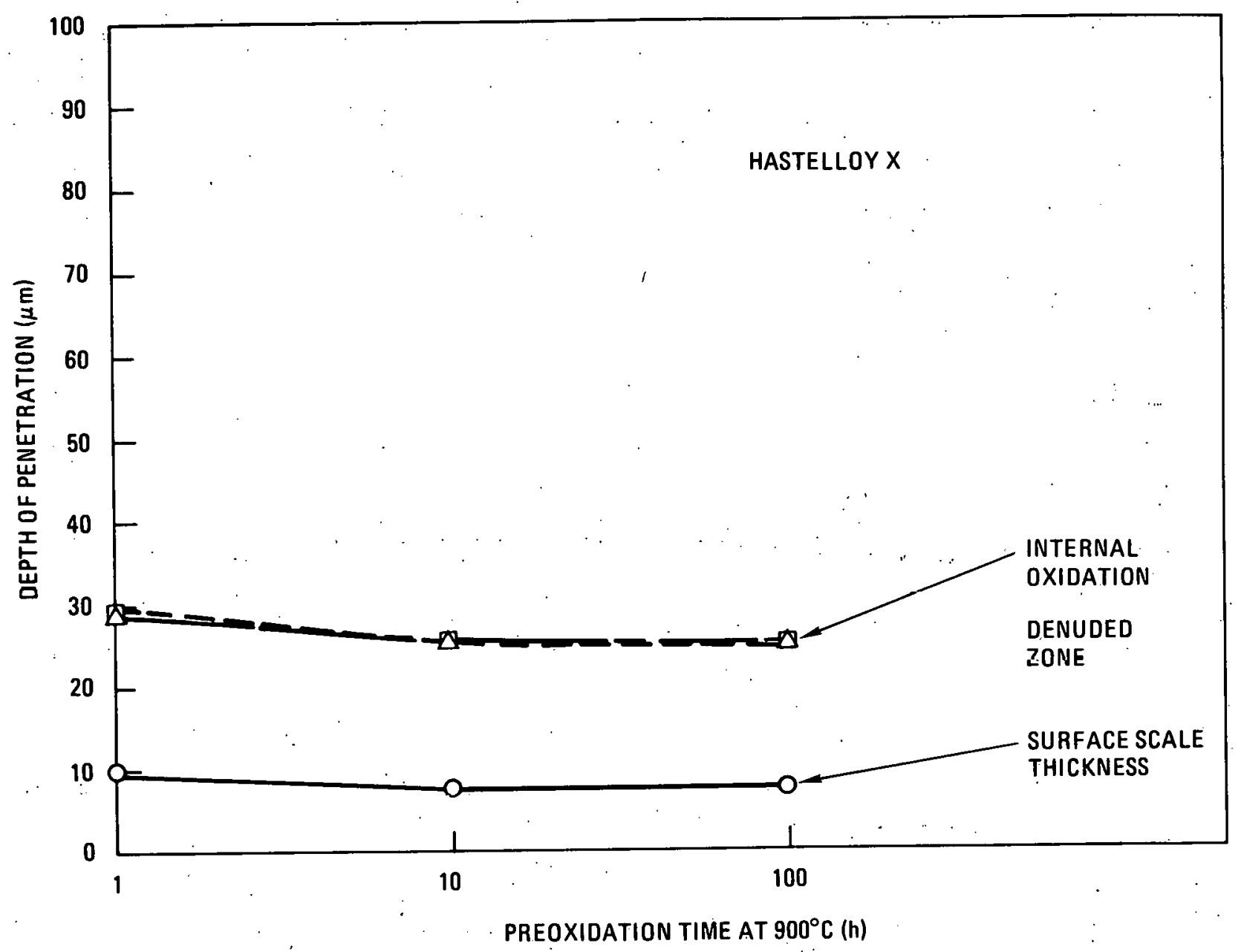

Fig. 59. Corrosion characteristics of preoxidized Hastelloy $\mathrm{X}$ specimens exposed $3000 \mathrm{~h}$ at $900^{\circ} \mathrm{C}$ in controlled-inpurity helium containing

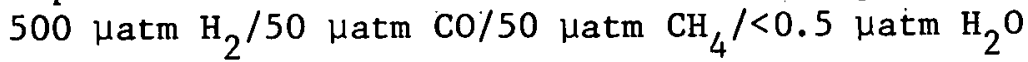




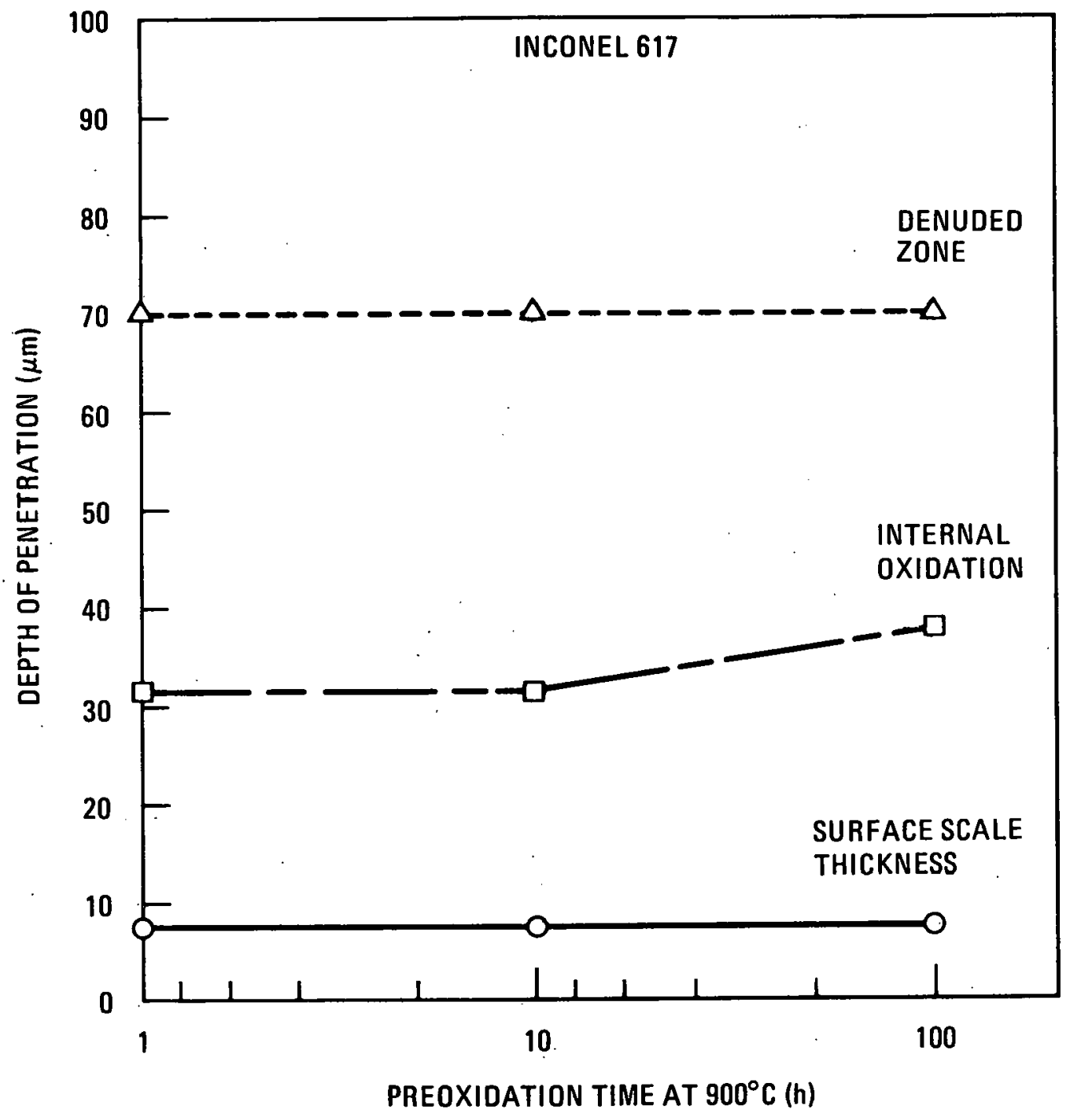

Fig. 60. Corrosion characteristics of preoxidized Inconel 617 specimens exposed $3000 \mathrm{~h}$ at $900^{\circ} \mathrm{C}$ in controlled-impurity helium containing 500 patm $\mathrm{II}_{2} / 50$ matm $\mathrm{CO} / 50$ atm $\mathrm{CH}_{4} /<0.5$ Hatm $\mathrm{H}_{2} \mathrm{n}$ 


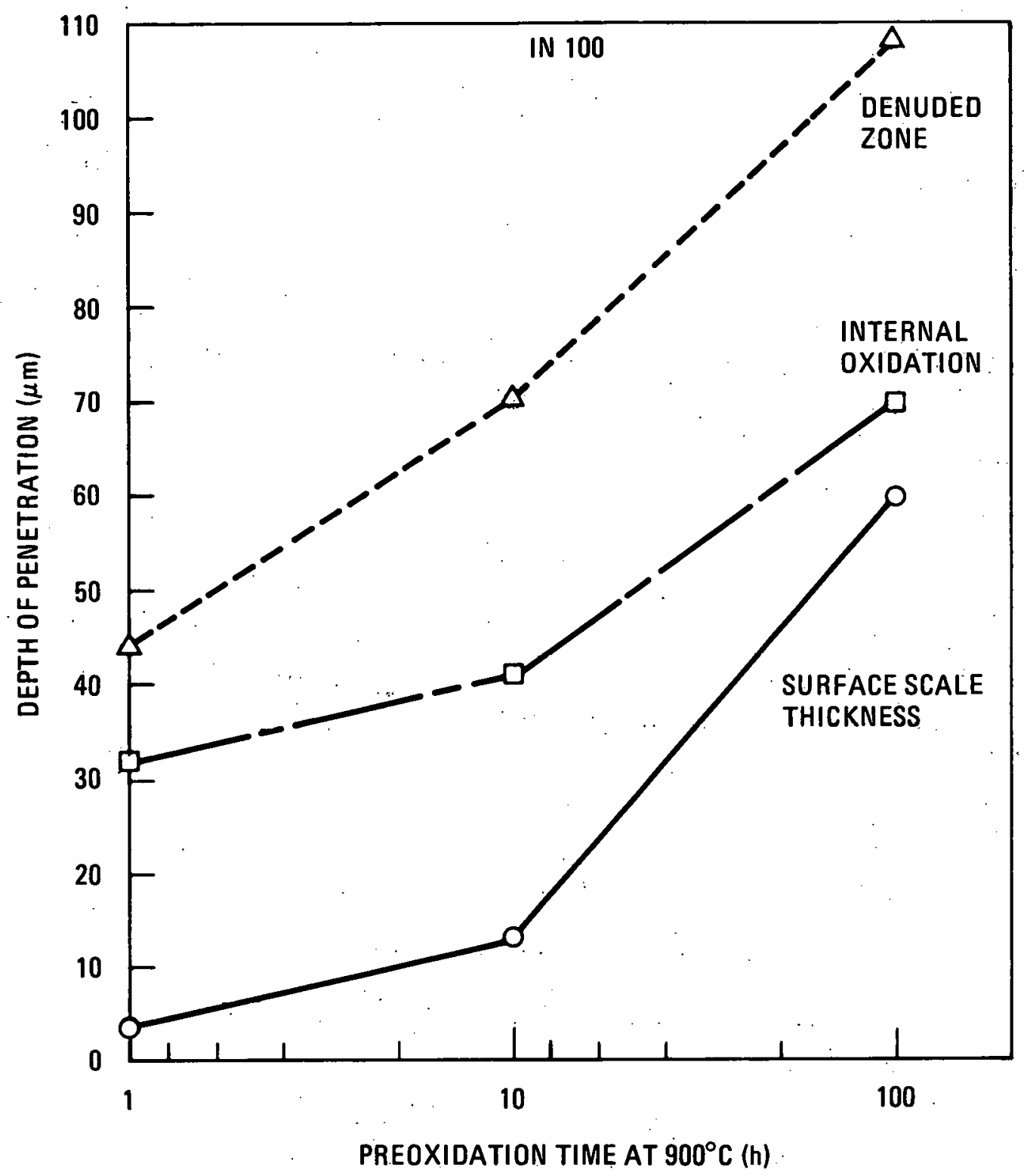

Fig. 61. Corrosion characteristics of preoxidized IN 100 specimens exposed $3000 \mathrm{~h}$ at $900^{\circ} \mathrm{C}$ in controlled-impurity helium containing

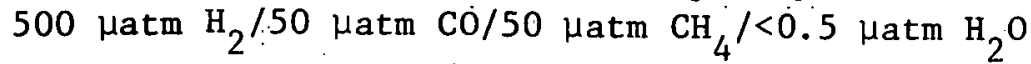




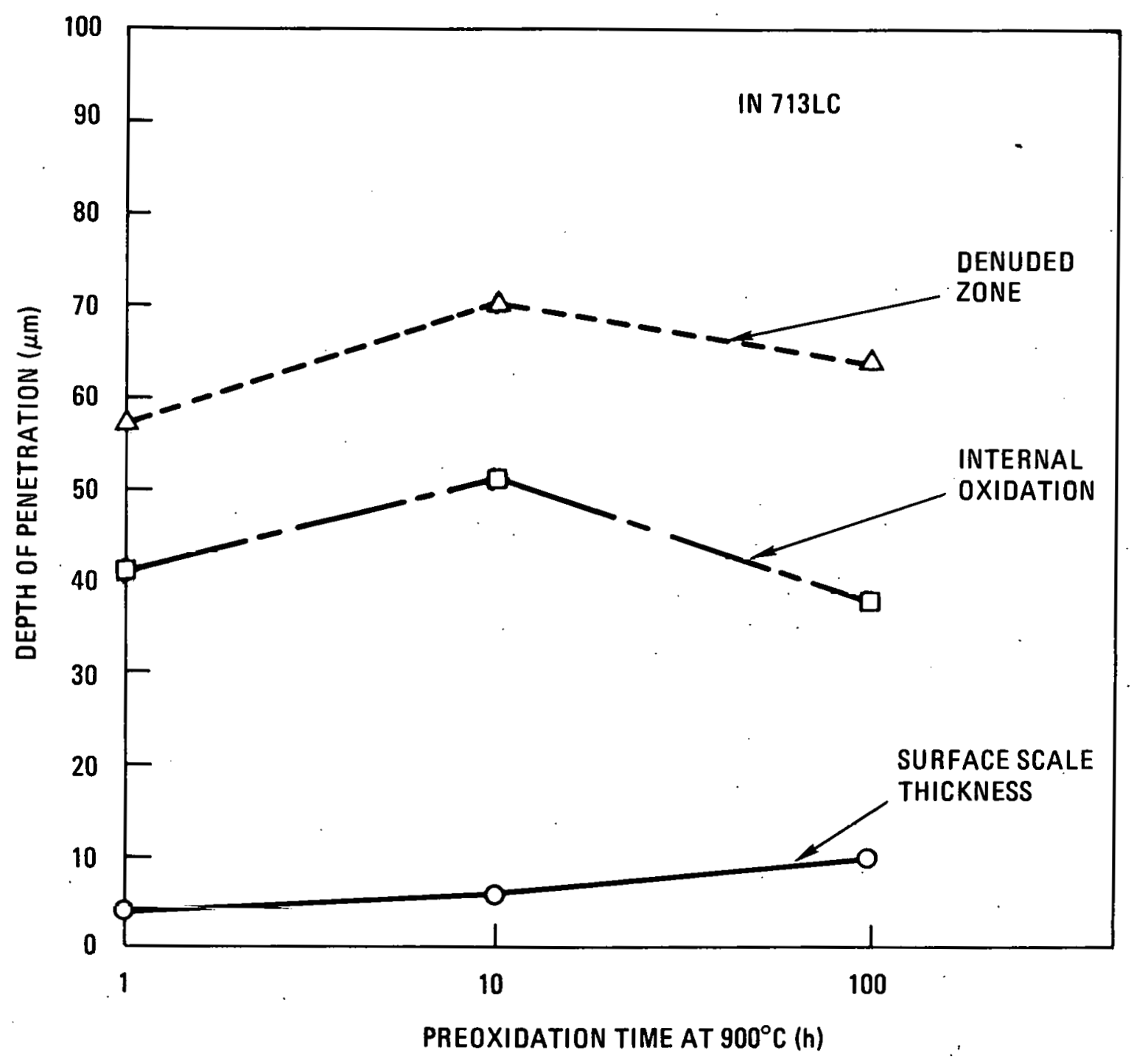

Fig. 62. Corrosion characteristics of preoxidized IN $713 \mathrm{LC}$ specimens exposed $3000 \mathrm{~h}$ at $900^{\circ} \mathrm{C}$ in controlled-impurity helium

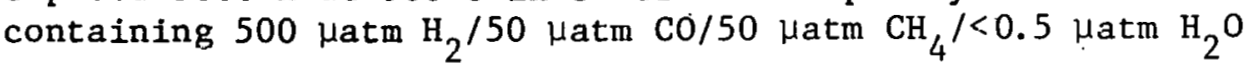




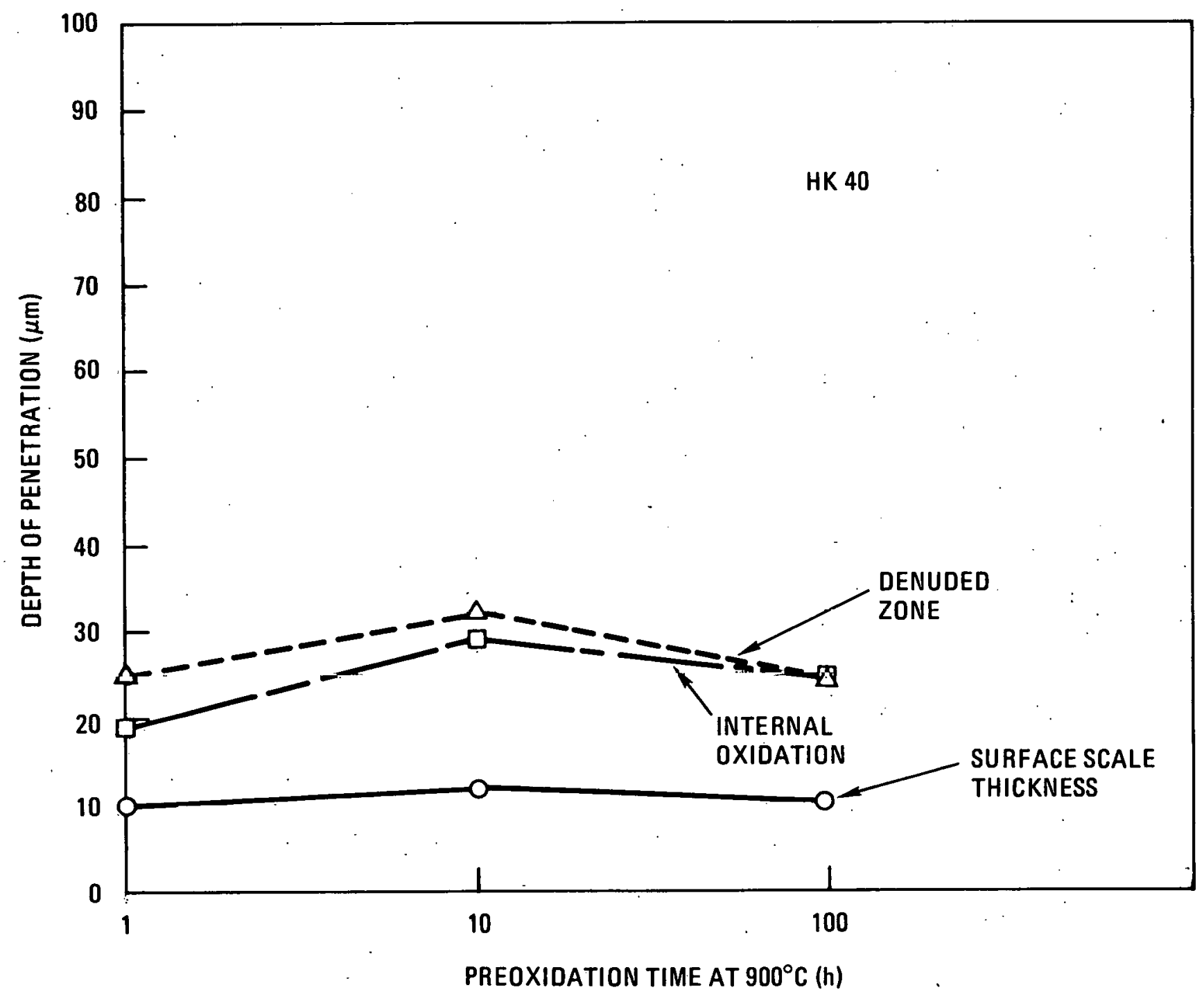

Fig. 63. Corrosion characteristics of preoxidized HK 40 specimens exposed $3000 \mathrm{~h}$ at $900^{\circ} \mathrm{C}$ in controlled-impurity helium containing

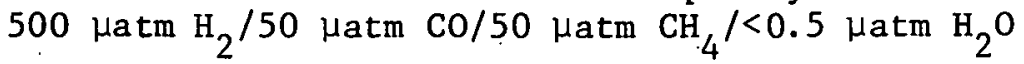




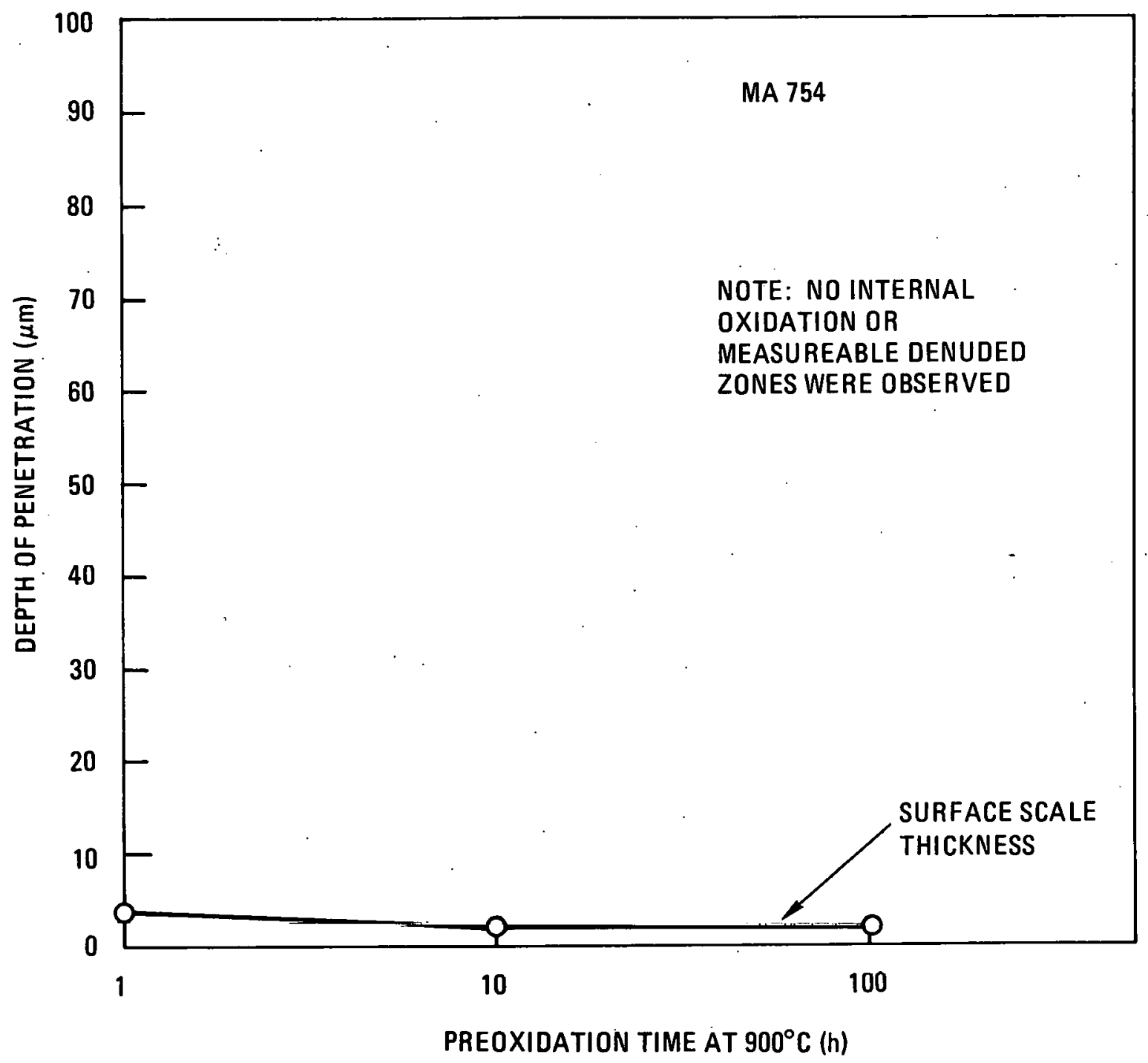

Fig. 64. Corrosion characteristics of preoxidized MA 754 specimens exposed $3000 \mathrm{~h}$ at $900^{\circ} \mathrm{C}$ in controlled-impurity helium containing

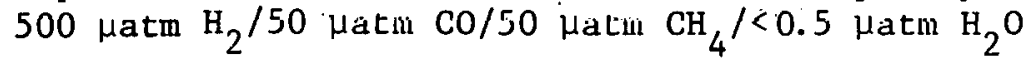


that $\mathrm{Cr}_{2} \mathrm{O}_{3}$-type oxides, formed in air, have a defect structure that inhibits carbon diffusion. These initial temporary carbon barriers gave way to more stable oxide spinel films, and these steady-state films remained diffusion barriers with respect to carbon ingress.

By making proper utilization of diffusion barriers (directly applied coatings, preoxidized scales, claddings, etc.) it should be possible to control the carburization normally observed for many alloys in simulated reactor helium environments. 


\section{CONCLUSIONS}

The conclusions from the first part of the study on the effects of prior surface condition are as follows:

1. Preoxidation treatments in air at $900^{\circ} \mathrm{C}$ have been shown to inhibit carburization of Alloy $800 \mathrm{H}$ and Hastelloy $X$ for $3000 \mathrm{~h}$ in a simulated reactor helium exposure, also at $900^{\circ} \mathrm{C}$.

2. Preoxidation treatments in air at $900^{\circ} \mathrm{C}$ increased the severity of carburization observed for IN 100 in a simulated reactor helium exposure at $900^{\circ} \mathrm{C}$, as compared to lapped or grit-blasted surfaces where carburization resistance was adequate.

3. Surface finish had no important effect upon the simulated reactor helium corrosion behavior of alloys HK 40 and MA 754 and only a minor effect upon the corrosion behavior of IN 713LC and Inconel 617.

4. Decarburization was observed for all surface conditions of MA 754 following exposures in a simulated reactor helium environment.

5. Although thermodynamically unstable, oxide scales formed in air can resist the carburization of some alloys during simulated reactor helium exposures. These scales transform to more stable forms of oxide which continue to be carburization barriers. 
6. Effective carburization-barrier scales appear to be based upon either the $\mathrm{Al}_{2} \mathrm{O}_{3}$ oxides containing titanium or spinels similar to $\mathrm{Cr}_{2} \mathrm{MnO}_{4}$. The protective nature of these scales is dependent upon the manner in which they are formed. Chromium-manganese oxide scales formed without preoxidation do not necessarily inhibit carburization. 


\section{RECOMMENDATIONS FOR FUTURE WORK}

The following recommendations are made for future research:

1. The experiments performed in this study were of a relatively short duration. Longer-term studies should be initiated to investigate not only long-term exposure stability characteristics of preoxidized scales but also the effects of preoxidation environment, temperature, and time on the performance of alloys in simulated reactor helium environments.

2. The spallation behavior of preoxidized surface scales should be studied with particular emphasis upon thermal cycling and reactor temperature profiles/environments. As a complementary area of study, the "self-healing" characteristics of protective preoxidized scales should be investigated. In addition, the kinetics and microstructural consequences of carburization in areas where spallation has occurred should be determined.

3. The use of $\mathrm{Fe}-\mathrm{Mn}-\mathrm{Cr}$ and Ni-Mn-Cr alloys as cladding/coating materials should be investigated. The manganese and chromium concentrations could be adjusted to the appropriate levels leading to the formation of protective "coatings" based on the $\mathrm{Cr}_{2} \mathrm{MnO}_{4}$ spinel, either during preoxidation treatments or during actual HTGR-GT environmental exposures.

4. Alloy design projects should be initiated with the objective of developing alloy systems that form protective scales based upon manganese spinels and alumina-based oxides when exposed to simulated reactor helium environments. Adequate mechanical properties for reactor operating conditions must, of course, be maintained in addition to acceptable corrosion behavior. 


\section{ACKNOWLEDGMENTS}

The author would like to thank R. B. Akin, W. C. Niven, and

S. S. Liang for their valuable assistance in specimen preparation, inspection, data reduction, documentation, and performance of the corrosion experiments. Gratitude is also expressed to P. K. Gantzel for conducting the X-ray analyses and to R. E. Villagrana and D. R. Wall for conducting the scanning electron microscopy and analyses.

Special thanks are extended to my colleague, W. R. Johnson, for reviewing the manuscript and lending his technical expertise during 'countless discussions. Also appreciated are the help in planning and intitiation and the continued support and encouragement throughout the course of this investigation given by S. N. Rosenwasser, Manager of the the Materials Evaluation Branch. 


\section{REFERENCES}

1. Rosenwasser, S. N., and W. R. Johnson, "Gas Turbine HTGR Materials Screening Test Program Interim Results," ERDA Report GA-A13931, General Atomic Company, June 30, 1976.

2. Rosenwasser, S. N., and W. R. Johnson, "Gas-Turbine and AdvancedHTGR Materials Screening Test Program, 10,000-Hour Results and Semiannual Progress Report for the Period Ending March 31, 1977," ERDA Report GA-A14407, General Atomic Company, July 1977.

3. Rosenwasser, S. N., and W. R. Johnson, "Gas-Turbine and AdvancedHTGR Materials Screening Test Program Semiannual Progress Report for: the Period March 31, 1977 through September 30, 1977," DOE Report GA-A14778, General. Atomic Company, January 1978.

4. Johnson, W. R., S. N. Rosenwasser, and L. D. Thompson, "The HighTemperature Corrosion of Advanced Gas-Cooled Reactor Candidate Materials in a Series of Simulated Reactor Helium Environments," paper presented at the 154th Meeting of the Electrochemical Society, Pittsburgh, Pennsylvania, October 15-20, 1978.

5. Johnson, W. R., and L. D. Thompson, "Effects of Methane Concentration on the Controlled-Impurity Helium Corrosion Behavior of Selected HTGR Structural Materials," DOE Report GA-A15565, General Atomic Company, December 1979.

6. Fortesque, P., "The Case for Gas Cooling," Nucl. Eng. Design 26, 3 (1974).

7. Bates, H.G.A., and P. L. Rittenhouse, "HTMP Corrosion Programme: Factors Affecting the Oxidation and Carburization of Metals in HTR Helium," HTMP Technical Note No. 6 , H1gh Temperalure Malelials Programme, c/o Flight Refuelling Limited, Wimborne, Dorset, England, BH2,1 2BJ, December 1976.

8. Rittenhouse, P. L., "Iron- and Nickel-Base Alloys for Environmental Screening in Connection with Project Work Statement MC-3," KFA Report IRW-IB-17/79, Kernforschungsanlage Jülich, GmbH, Institut für Reaktorwerkstoffe, Federal Republic of Germany, May 1979. 
9. Li, C. C., W. R. Johnson, and L. D. Thompson, "Influence of a Simulated HTGR Environment on the Mechanical Properties of a Commercial Ni-Cr-Mo-Fe Alloy (Hastelloy Alloy X)," DOE Report GA-A15564, General Atomic Company, December 1979.

10. Thuillier, J. A., "Better Tube Life in Ethylene Pyrolysis Furnaces," Materials Performance, (November 1976).

11. Mazandarany, F. N., and G. Y. Lai, "Corrosion Behavior of Selected Structural Materials in a Simulated Steam-Cycle HTGR Helium Environment," DOE Report GA-A14446, General Atomic Company, October 1977.

12. Villagrana, R. E., J. L. Kaae, J. R. Ellis, and P. K. Gantzel, "The Effect of Hardening Processes on the High-Temperature Low-Cycle Fatigue Behavior of Alloy $800 \mathrm{H}$; Part I: The Effect of Hardening Processes on the Initial Stress-Strain Curve," General Atomic Report GA-A14423, July 1977.

13. Lai, G. Y., "An Investigation of the Thermal Stability of a Commercial Ni-Cr-Fe-Mo Alloy (Hastelloy Alloy X)," DOE Report GA-A14279, General Atomic Company, February 1977.

14. Lai, G. Y., and L. D. Thompson, "Effects of Thermal Aging on the Mechanical Properties of a Ni-Cr-Mo-Fe Alloy," DOE Report GA-A15016, General Atomic Company, August 1978.

15. Collins, H. E., "Relative Long-Time Stability of Carbide and Intermediate Phases in Nickel-Base Superalloys," Trans. ASM 62, 82 (1969).

16. Bradley, E. F., ed., Source Book on Materials for Elevated-Temperature Applications, American Society for Metals, Metals Park, Ohio, 1979, p. 221.

17. "Inconel Alloy MA 754;" Huntington Alloys, Inc., Huntington, West Virginia.

18. Wright, I. G., "Oxidation of Iron-, Nickel-, and Cobalt-Base Alloys," Metals and Ceramics Information Center, Battelle Columbus Laboratories, Report MCIC-72-07, June 1972, pp. 32-40.

19. Wlodek, S. T., Trans. Met. Soc. AIME 230, 1078 (1964). 
20. Kondo, T., M. Shindo, and T. Suzuki, "Study on Material Corrosion and the Resultant Radioactive Product Formation in HTR Helium Environments," paper presented at the 1st U.S.-Japan Seminar on HTR Safety Technology, Helium Technology Session, Brookhaven Nationa1 Laboratory, U.S.A., September 15-16, 1977.

21. Kondo, T., M. Shindo, and K. Kiuchi, "Characterization of the Metal-Environment Interactions in Corrosion and Creep of Structural Alloys in the HTR Helium Environments," (cited in Ref. 20). 